1 Supporting Information for:

2

3

\title{
The formation of highly oxidized multifunctional products in the ozonolysis of cyclohexene
}

Matti P. Rissanen* ${ }^{1}$, Theo Kurtén ${ }^{2}$, Mikko Sipilä ${ }^{1}$, Joel A. Thornton ${ }^{3}$, Juha Kangasluoma ${ }^{l}$, Nina Sarnela ${ }^{l}$, Heikki Junninen ${ }^{l}$, Solvejg Jørgensen ${ }^{4}$, Simon Schallhart ${ }^{l}$, Maija K. Kajos ${ }^{l}$, Risto Taipale ${ }^{l}$, Taina Ruuskanen ${ }^{l}$, Tuukka Petäjä ${ }^{1}$, Douglas R. Worsnop ${ }^{5}$, Henrik G. Kjaergaard ${ }^{4}$ and Mikael Ehn ${ }^{l}$

${ }^{1}$ Department of Physics, P.O. Box 64, 00014 University of Helsinki, Finland.

${ }^{2}$ Department of Chemistry, P.O. Box 55, 00014 University of Helsinki, Finland.

${ }^{3}$ Department of Atmospheric Sciences, University of Washington, Seattle, WA 98195, USA.

${ }^{4}$ Department of Chemistry, University of Copenhagen, Universitetsparken 5, 2100 Copenhagen Ø, Denmark.

${ }^{5}$ Aerodyne Research Inc., 45 Manning Road, Billerica, MA 01821, USA.

\section{S1. Experimental}

\section{S1.1. Laboratory investigations}

The CI-APi-TOF mass spectrometer (Tofwerk AG, Switzerland), the nitrate chemical ionization scheme and the measurement routines have been described previously ${ }^{62,63}$. Briefly, the atmospheric pressure sample is introduced to the chemical ionization inlet by 3/4-inch stainless steel tube. In the CI-inlet, sheath flow carries the charged nitrate clusters and an applied electric field introduces the ions into the sample gas flow. The charging is brought about (mainly) by nitrate dimers (i.e., $\mathrm{HNO}_{3}{ }^{*} \mathrm{NO}_{3}{ }^{-}$), and adducts between sample molecules and the $\mathrm{NO}_{3}{ }^{-}$ion form if the bond between the sample molecule and $\mathrm{NO}_{3}{ }^{-}$is stronger than the bond between $\mathrm{HNO}_{3}$ and $\mathrm{NO}_{3}{ }^{-}$. Contrary to a previous publication ${ }^{62}$ the ionizing radiation in the CI-inlet was provided by a Hamamatsu L9490 soft X-ray photoionizer, which has been tested against the more commonly applied Americium 241 radioactive charger and has been found to give consistent results.

The ozonolysis reactions $\left(\mathrm{C}_{6} \mathrm{H}_{10}, \mathrm{C}_{6} \mathrm{D}_{10}\right.$ and cis-6-nonenal) were investigated in two borosilicate glass flow tube reactors $(205 \mathrm{~cm}$ long $/ 4.7 \mathrm{~cm}$ i.d. and $63 \mathrm{~cm}$ long/4.0 cm i.d.) coupled to a nitrate CI-APi-TOF mass spectrometer (see Figure S1). The reagents were brought into the flow tubes with $0.4 \mathrm{~cm}$ i.d. Nylon or Teflon tubing, connected to the reactor by a $1 \mathrm{~cm}$ i.d. cross Swagelok tube fitting and located in a $0.7 \mathrm{~cm}$ i.d. contraction, at about $5 \mathrm{~cm}$ upstream of the flow reactor. All experiments were performed at room temperature $(T=293 \pm 3 \mathrm{~K})$ and at ambient pressure using nitrogen $\left(\mathrm{N}_{2}\right)$ or synthetic air $\left(\mathrm{N}_{2}\right.$ and $\left.\mathrm{O}_{2}\right)$ as the bath gas. Generally the volumetric flow rate was adjusted to $11 \mathrm{dm}^{3} \mathrm{~min}^{-1}$, which resulted in about $19 \mathrm{~s}$ and S1 
$4 \mathrm{~s}$ residence times in the larger and smaller flow reactors, respectively. The gas flow velocities inside the flow tubes were varied in few of the experiments to inspect its possible effect on the ELVOC product distributions obtained. All experiments were performed under laminar flow conditions.

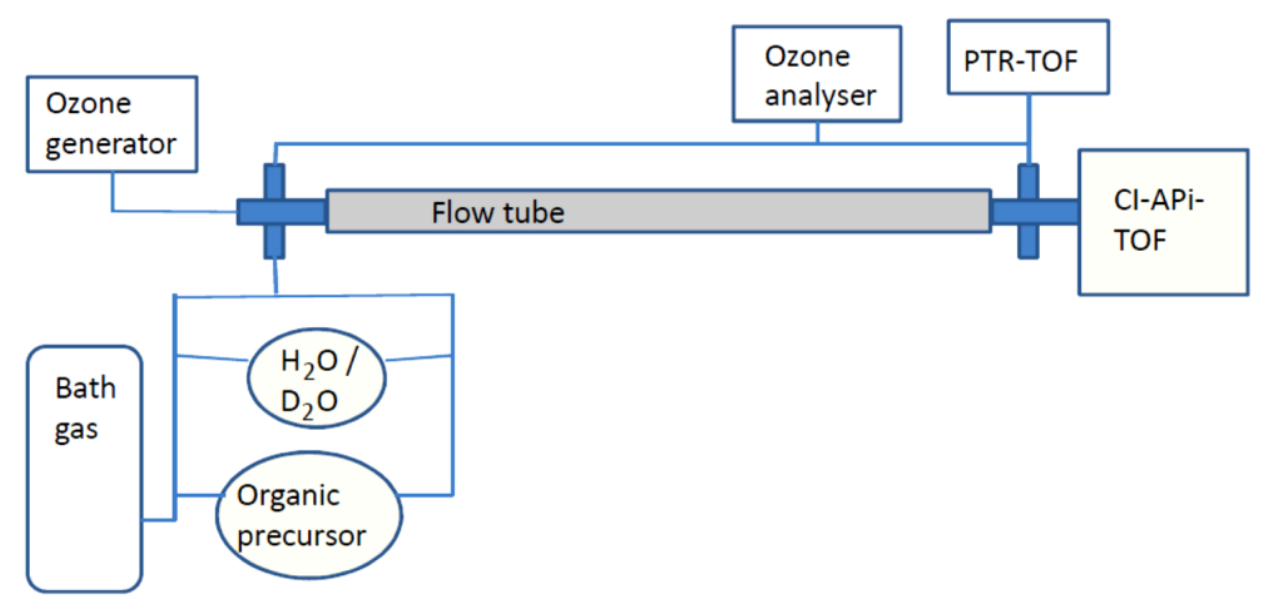

Figure S1 Simplified schematic of the experimental setup.

The concentration of cyclohexene in the gas flow was generally estimated from the vapor pressure of the precursor and the measured gas flows, but in some of the experiments the concentrations were directly determined using a PTR-TOF-MS (Proton Transfer Reaction Time-of-Flight Mass Spectrometer). The PTRTOF-MS instrument consists of a proton transfer reaction (PTR) ion source and reaction chamber (Ionicon Analytik $\mathrm{GmbH}$, Austria), where the VOCs of the sample air are ionized by hydronium ions $\left(\mathrm{H}_{3} \mathrm{O}^{+}\right)$, and which is coupled to a time-of-light mass spectrometer (Tofwerk AG, Switzerland). A detailed description of the method can be found in ${ }^{64,65}$. For the experiments, the PTR-TOF-MS was calibrated (see Taipale et al. ${ }^{66}$ for details about the calibration set up) with a calibration gas mixture (Apel-Riemer Environmental Inc., USA) consisting of 16 different VOCs that was diluted with air purified by a catalytic converter. Ozone $\left(\mathrm{O}_{3}\right)$ concentration was measured concomitantly from the inflow and outflow of the flow reactor by an ozone analyzer (Thermo Scientific Model 49). Water $\left(\mathrm{H}_{2} \mathrm{O}\right.$ or $\left.\mathrm{D}_{2} \mathrm{O}\right)$ was added to the gas flow by bubbling a variable part of the bath gas flow through a water reservoir. The amount of water in the gas flow was not quantified further. The various types of experiments performed have been described in Table S1. 
Table S1 Description of the experiments performed.

\begin{tabular}{|c|c|c|c|c|c|c|}
\hline Reagent & $\begin{array}{l}\text { Reactor } \\
\text { used }\end{array}$ & $\begin{array}{l}\text { Volumetric } \\
\text { flow, flow } \\
\text { velocity, } \\
\text { residence } \\
\text { time / } \text { dm }^{3} \\
\text { min }^{-1}, \mathrm{~m} \mathrm{~s}^{-1}, \mathrm{~s}\end{array}$ & Bath gas & $\begin{array}{l}{ }^{a}\left[\mathrm{O}_{3}\right] \text { range } \\
/ \mathbf{1 0}^{12} \\
\text { molecule } \\
\mathrm{cm}^{-3}\end{array}$ & $\begin{array}{l}\text { Added water; } \\
\mathrm{H}_{2} \mathrm{O} \text { or } \mathrm{D}_{2} \mathrm{O}\end{array}$ & $\begin{array}{l}\text { [Alkene] range } \\
/ \mathbf{1 0}^{14} \text { molecule } \\
\mathrm{cm}^{-3}\end{array}$ \\
\hline Cyclohexene & $\begin{array}{l}{ }^{b} \text { long and } \\
\text { short }\end{array}$ & $\begin{array}{l}11.4-15.6, \\
0.11-0.2,4-19 \\
\end{array}$ & $\begin{array}{l}\text { Synthetic } \\
\text { air, } \mathrm{N}_{2}\end{array}$ & $0.01-1.97$ & $\mathrm{H}_{2} \mathrm{O} / \mathrm{D}_{2} \mathrm{O}$ & $0.7-96.0$ \\
\hline Cyclohexene d10 & long & $\begin{array}{l}\begin{array}{l}11.4-21.4, \\
0.11-0.2, \\
19\end{array} \\
\end{array}$ & $\begin{array}{l}\text { Synthetic } \\
\text { air, } \mathrm{N}_{2}\end{array}$ & $0.01-1.97$ & $\mathrm{H}_{2} \mathrm{O} / \mathrm{D}_{2} \mathrm{O}$ & $0.44-14.7$ \\
\hline cis-6-nonenal & $\begin{array}{l}\text { long and } \\
\text { short }\end{array}$ & $\begin{array}{l}5-11.5, \quad 0.11- \\
0.15,4-19\end{array}$ & Air, $\mathrm{N}_{2}$ & $0.01-2.46$ & $-/ \mathrm{D}_{2} \mathrm{O}$ & $0.05-3.6$ \\
\hline
\end{tabular}

${ }^{a}$ Concentration given by Thermo Scientific Model 49 Ozone Analyzer. ${ }^{b}$ Long $=205 \mathrm{~cm}, 4.7 \mathrm{~cm}$ i.d. reactor; short $=63 \mathrm{~cm}, 4.0$ i.d. reactor.

Experiments were conducted under increasingly oxidizing conditions that enabled studying the oxidation reactions further. During the experiments, more $\mathrm{O}_{3}$ and organic precursor were added to the gas flow, which resulted in higher concentrations of radicals and intermediates in the mixture, and correspondingly higher probabilities for secondary reactions of the radicals formed. This was done in order to inspect the outcome of peroxy radical reactions (i.e., $\mathrm{RO}_{2}+\mathrm{R}^{\prime} \mathrm{O}_{2}$, where $\mathrm{R}^{\prime}=\mathrm{H}$ or an alkyl-type group, possibly $\mathrm{R}=\mathrm{R}^{\prime}$ ), and to reach conditions where the products of the $\mathrm{RO}_{2}+\mathrm{RO}_{2}$ reaction can be seen with high enough signals for unambiguous identification.

\section{S1.2. Chemicals}

The chemicals cyclohexene $\left(c-\mathrm{C}_{6} \mathrm{H}_{10}, 99.0 \%\right)$, deuterated cyclohexene $\left(c-\mathrm{C}_{6} \mathrm{D}_{10}, 98 \%\right)$, cis-6-nonenal $\left(\mathrm{CH}_{3} \mathrm{CH}_{2} \mathrm{CH}=\mathrm{CH}\left(\mathrm{CH}_{2}\right)_{4} \mathrm{CHO}, 92.0 \%\right)$ and deuterated water $\left(\mathrm{D}_{2} \mathrm{O}, 99.9 \%\right)$ were obtained from the Aldrich chemical company. The water $\left(\mathrm{H}_{2} \mathrm{O}\right)$ used was deionized and filtered with Millipore. The gases, nitrogen $\left(\mathrm{N}_{2}\right.$, cryogenic supply and 6.0 scientific grade, $99.999 \%$ and $99.9999 \%$, respectively) and synthetic air $\left(\mathrm{N}_{2}\right.$ and $\mathrm{O}_{2}$, 99.999\%) were obtained from AGA. Ozone $\left(\mathrm{O}_{3}\right)$ was produced by a commercial ozone generator Dasibi 1008-PC, either from synthetic air or from pressurized and filtered air. All the chemicals were used without further purification.

\section{S1.3. Uncertainties}

It should be pointed out that the ELVOC yield determined here is very sensitive to the calibration factor used, and thus the CI-APi-TOF was calibrated with sulfuric acid $\left(\mathrm{H}_{2} \mathrm{SO}_{4}\right)$ by producing a known amount of it from a reaction of $\mathrm{SO}_{2}$ with $\mathrm{OH}$-radicals, $\mathrm{O}_{2}$ and $\mathrm{H}_{2} \mathrm{O}$ (more on calibration below) [see ref. ${ }^{91}$, and references therein]. However, the ion transmission efficiencies for ELVOCs and $\mathrm{H}_{2} \mathrm{SO}_{4}$ most likely differ, and thus 
using a calibration coefficient determined for $\mathrm{H}_{2} \mathrm{SO}_{4}$ adds uncertainty to the values obtained. Other sources of uncertainty result mainly from calibration of mass flow controllers (i.e., gas flow rates and their calculations), ELVOC wall loss rate(-s), impurities in gas flows capable of reacting with the ELVOC precursors (e.g., $\mathrm{HO}_{2}$ and $\mathrm{RO}_{2}$ radicals produced from impurities) and uncertainties in determined $\mathrm{O}_{3}$ concentrations. By adding the different uncertainties with a propagation of error method, one arrives at an estimated total uncertainty of the ELVOC yield of $(4.5 \pm 3.8) \%$ for the $\mathrm{C}_{6} \mathrm{H}_{10}+\mathrm{O}_{3}$ reaction (i.e., $80 \%$ estimated overall uncertainty; more on yield below).

\section{S1.4. Water addition}

We cannot detect individual $\mathrm{H}_{2} \mathrm{O}$ (or $\mathrm{D}_{2} \mathrm{O}$ ) directly with the experimental setup, but we have an indirect proxy for the water abundance in the system; the $\mathrm{H}_{2} \mathrm{O} * \mathrm{NO}_{3}{ }^{-}$complex (or equivalently $\mathrm{D}_{2} \mathrm{O}^{*} \mathrm{NO}_{3}{ }^{-}$when using $\mathrm{D}_{2} \mathrm{O}$ ). We found no evidence that indicates a role for water in the ELVOC formation. This is illustrated in Figure S2, where a few of the major ELVOC signals obtained are plotted together with the $\mathrm{H}_{2} \mathrm{O}^{*} \mathrm{NO}_{3}{ }^{-}$ complex signal for one set of these experiments.

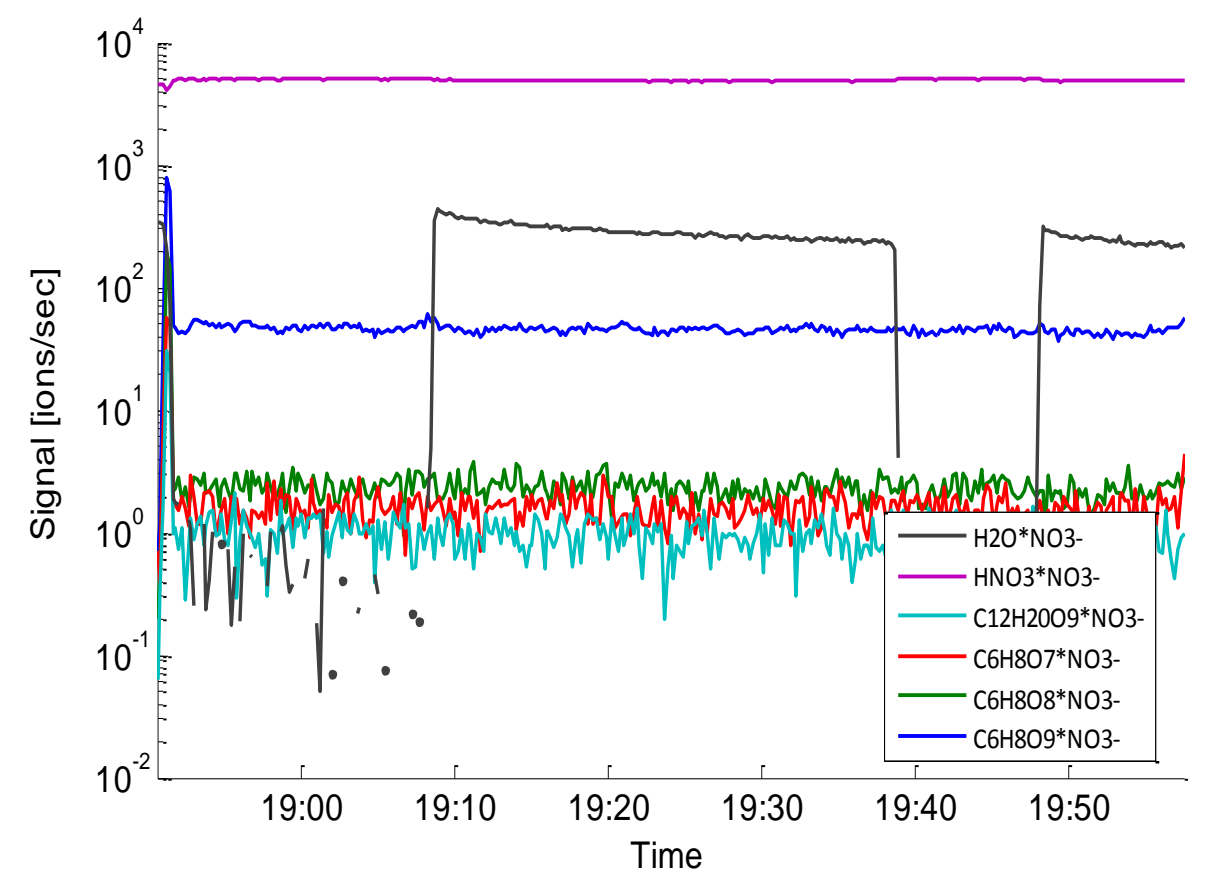

Figure S2 The identified ELVOC signals remain constant when $\mathrm{H}_{2} \mathrm{O}$ is added to the gas flow. The addition can be seen from the sharp rise of the water-nitrate-ion complex signal $\left(\mathrm{H}_{2} \mathrm{O}^{*} \mathrm{NO}_{3}{ }^{-}\right)$at 79.9989 Th. The ELVOC signals shown are: $\mathrm{C}_{6} \mathrm{H}_{8} \mathrm{O}_{9}, \mathrm{C}_{6} \mathrm{H}_{8} \mathrm{O}_{8}$ and $\mathrm{C}_{6} \mathrm{H}_{8} \mathrm{O}_{7}$, detected as clusters with $\mathrm{NO}_{3}{ }^{-}$at $286.0052 \mathrm{Th}$, 270.0103 Th and 254.0154 Th, respectively.

By adding $\mathrm{D}_{2} \mathrm{O}$ to the gas flow, instead of $\mathrm{H}_{2} \mathrm{O}$, we can get information on the chemical identity of the products formed, as acidic groups will exchange hydrogens easily ${ }^{29,85-87}$. The deuterium atom is one mass S4 
unit heavier than the hydrogen atom, and thus the identified ELVOC should shift one mass unit in the spectra for every exchangeable hydrogen atom in the ELVOC molecule. These investigations suggested that the product observed at $254.0154 \mathrm{Th}\left(\mathrm{C}_{6} \mathrm{H}_{8} \mathrm{O}_{7}\right)$ is formed through one $\mathrm{O}_{2}$ addition step earlier intermediate than the 270.0103 Th and 286.0052 Th peaks (i.e., $\mathrm{C}_{6} \mathrm{H}_{8} \mathrm{O}_{8}$ and $\mathrm{C}_{6} \mathrm{H}_{8} \mathrm{O}_{9}$ ). This is because the 254.0154 Th peak was observed to shift only by two mass units, whereas the 270.0103 Th and 286.0052 Th peaks shifted by 3 mass units, indicating that 2 and 3 hydrogens were exchanged by $\mathrm{D}_{2} \mathrm{O}$ addition to the reaction mixture, respectively (see Figures $1 \mathrm{~b}$ and S3). This further suggests that the third hydroperoxide functionality is not yet formed in the 254.0154 Th's parent compound, the $\mathrm{C}_{6} \mathrm{H}_{9} \mathrm{O}_{8}$ peroxy radical (see Scheme 2).
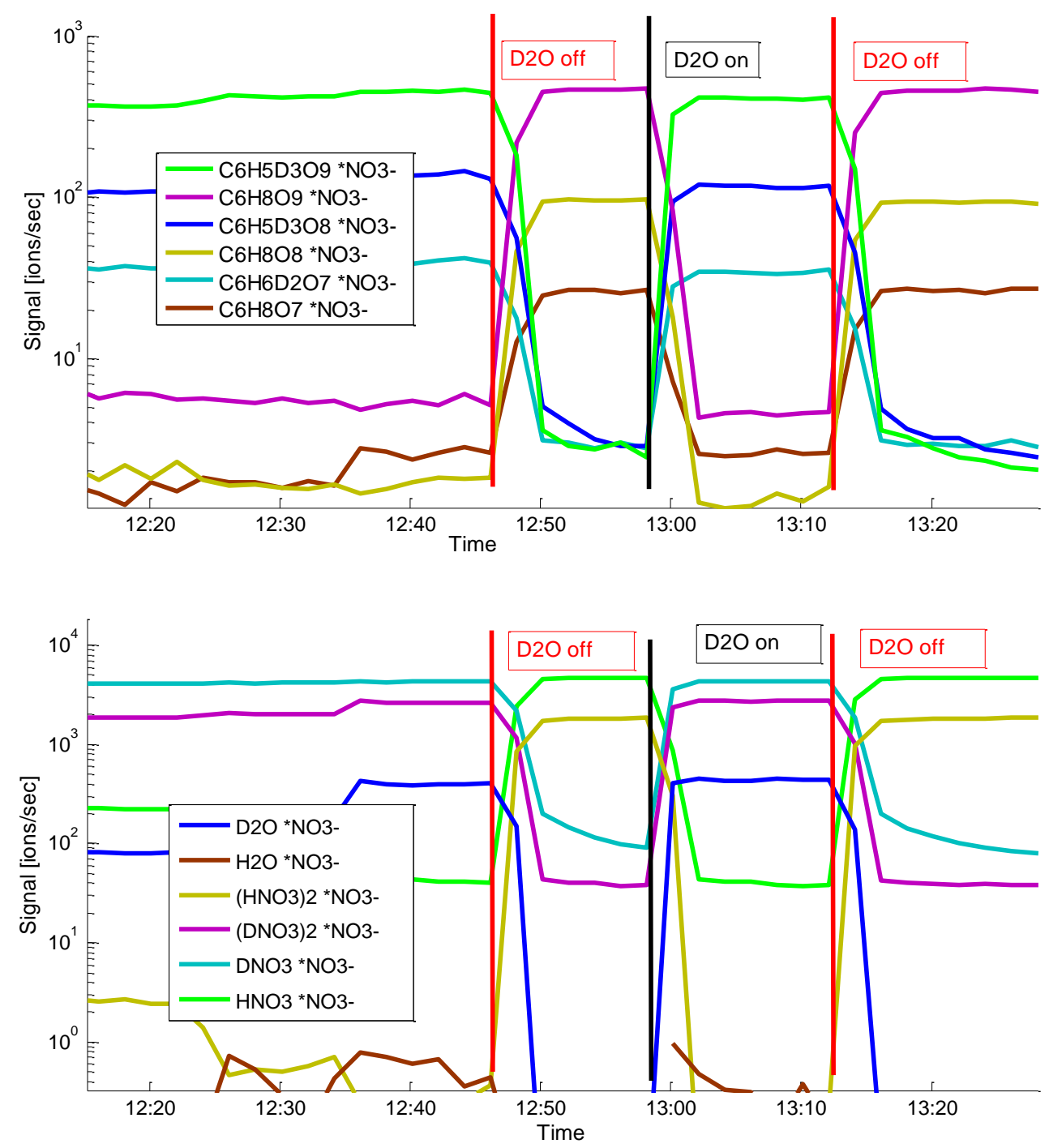

Figure S3 An example of how cyclohexene ozonolysis derived ELVOC signals shift in mass after adding $\mathrm{D}_{2} \mathrm{O}$ to the gas flow (e.g., $\mathrm{C}_{6} \mathrm{H}_{8} \mathrm{O}_{9} \rightarrow \mathrm{C}_{6} \mathrm{H}_{5} \mathrm{D}_{3} \mathrm{O}_{9}$ ). Also the charger nitrate clusters shift according to the amount of acidic hydrogens in the clusters. 


\section{S1.5. Deuterated cyclohexene, $C_{6} D_{10}$}

The ELVOCs observed in the ozonolysis of deuterated cyclohexene were given in Table 1 and Figure 3, and the general monomer formation mechanism is believed to be analogous to the non-substituted cyclohexene ozonolysis system (see Scheme 2). By inspecting the mechanism and the peaks identified, it is observed that multiple D-atoms are exchanged to $\mathrm{H}$-atoms before detection in both of the main products, i.e., the ELVOC product at 275.0417 Th is detected with a composition $\mathrm{C}_{6} \mathrm{D}_{5} \mathrm{H}_{3} \mathrm{O}_{8}$ (corresponding to $\mathrm{C}_{6} \mathrm{H}_{8} \mathrm{O}_{8}$ in the $\mathrm{C}_{6} \mathrm{H}_{10}+$ $\mathrm{O}_{3}$ reaction) and the 293.0491 Th product is observed to have a composition $\mathrm{C}_{6} \mathrm{D}_{7} \mathrm{HO}_{9}$ (corresponding to $\mathrm{C}_{6} \mathrm{H}_{8} \mathrm{O}_{9}$ in the $\mathrm{C}_{6} \mathrm{H}_{10}+\mathrm{O}_{3}$ reaction). In addition, the $\mathrm{C}_{6} \mathrm{D}_{5} \mathrm{H}_{3} \mathrm{O}_{9}$ at $291.0366 \mathrm{Th}$, the $\mathrm{C}_{6} \mathrm{D}_{7} \mathrm{HO}_{8}$ at $277.0542 \mathrm{Th}$ and the fully deuterated ELVOCs at $278.0605 \mathrm{Th}\left(\mathrm{C}_{6} \mathrm{D}_{8} \mathrm{O}_{8}\right)$ and $294.0554 \mathrm{Th}\left(\mathrm{C}_{6} \mathrm{D}_{8} \mathrm{O}_{9}\right)$ are seen but with reduced intensity.

By looking at the Figures 1a and 3a it is clear that the distribution of oxidation products has changed upon exchanging $\mathrm{H}$-atoms with $\mathrm{D}$-atoms in the cyclohexene precursor molecule. The deuterated ELVOC, $\mathrm{C}_{6} \mathrm{D}_{8} \mathrm{O}_{9}$ (a major part of it is seen as $\mathrm{C}_{6} \mathrm{D}_{7} \mathrm{HO}_{9}$ in the spectra at 293.0491 Th and less as $\mathrm{C}_{6} \mathrm{D}_{5} \mathrm{H}_{3} \mathrm{O}_{9}$ at 291.0366 Th), corresponding to the major monomer ELVOC detected in the $\mathrm{C}_{6} \mathrm{H}_{10}+\mathrm{O}_{3}$ reaction (i.e., $286.0052 \mathrm{Th}$, $\mathrm{C}_{6} \mathrm{H}_{8} \mathrm{O}_{9}$ ), is seen with much lower intensity (see Figures 1 and 3 for the spectra), as expected due to slower D-transfer reactions compared to H-transfer reactions, and also due to more probable tunneling for the lighter $\mathrm{H}$-atoms ${ }^{84}$. In fact, the major monomer product observed in the $\mathrm{C}_{6} \mathrm{D}_{10}+\mathrm{O}_{3}$ reaction is $\mathrm{C}_{6} \mathrm{D}_{5} \mathrm{O}_{8} \mathrm{H}_{3}$, detected at 275.0417 Th, and corresponding to the 270.0103 Th product of the $\mathrm{C}_{6} \mathrm{H}_{10}+\mathrm{O}_{3}$ reaction $\left(\mathrm{C}_{6} \mathrm{H}_{8} \mathrm{O}_{8}\right)$; with three D-atoms exchanged prior to detection. Also, the product distribution has shifted toward the middle product due to hindered atom transfer of $\mathrm{D}$ in comparison with $\mathrm{H}$.

\section{S1.6. Dimers}

When the $\mathrm{O}_{3}$ and cyclohexene concentrations are increased enough, dimers appear in the spectra (Table 1, Figures 1 and 3). The dimers in this context are not dimers in the most conventional sense, that is, they're not formed by two similar pieces sticking together by Van der Waals forces and hydrogen bonds. Instead, they are distinctive species formed in the recombination and cross-combination reactions of different $\mathrm{RO}_{2}$ radicals $^{12}$. This can be seen from, for example, their elemental compositions, as the dimers have more than double the amount of hydrogens than the monomer species (i.e., they're not clusters of the same species).

In dimers the effect of $\mathrm{OH}$-chemistry (which runs in parallel with ozonolysis, if no scavengers have been applied) is seen to interfere as we detect dimer compounds that apparently have not lost $\mathrm{H}$-atoms during the oxidation sequence (e.g., $\mathrm{C}_{12} \mathrm{H}_{20} \mathrm{O}_{\mathrm{x}}$ species in Table 1). This indicates that there are some $\mathrm{RO}_{2}$ species reacting which have more hydrogens than the original $\mathrm{C}_{6} \mathrm{H}_{10}$ parent molecule, which is in contrast with 
Scheme 2 where the first $\mathrm{H}$-atom is lost in the prompt VHP decomposition. This can be explained by OHchemistry, as the $\mathrm{OH}$ addition to the double bond of cyclohexene leads to a carbon-centered radical that has one $\mathrm{H}$ - and $\mathrm{O}$-atom more than the unsaturated parent compound; cyclohexene $\left(\mathrm{C}_{6} \mathrm{H}_{10}\right)$ will be converted to a carbon-centered hydroxycyclohexyl radical $\left(\cdot{ }_{6} \mathrm{C}_{6} \mathrm{H}_{10} \mathrm{OH}\right)$ that adds an $\mathrm{O}_{2}$ molecule and forms an oxygencentered hydroxycyclohexyl peroxy radical $\left(\cdot \mathrm{O}_{2} \mathrm{C}_{6} \mathrm{H}_{10} \mathrm{OH} ; \mathrm{C}_{6} \mathrm{H}_{11} \mathrm{O}_{3}\right)$. When these radicals react with the peroxy radical intermediates from Scheme 2, we obtain the dimer products with a carbon and hydrogen composition of $\mathrm{C}_{12} \mathrm{H}_{20}$ (see Figure 1 and Table 1).

Also another type of dimers in Table 1 might cause confusion at first - those with one less carbon atom in the elemental formula, i.e., $\mathrm{C}_{11}$-compounds. As shown in the current and previous work ${ }^{14,17,20}$, H-shifts leading to carbon-centered acyl-type radicals may lead to breakage of the carbon backbone by ejecting a COfragment. In cyclohexene ozonolysis, a $\mathrm{C}_{5}$ carbon-centered alkyl-type radical is created concurrently (Scheme 2), which can add an $\mathrm{O}_{2}$ molecule, forming a new $\mathrm{C}_{5}$ peroxy radical, and react with the abundant $\mathrm{C}_{6}$ peroxy radicals creating the $\mathrm{C}_{11}$-dimers observed.

The $\mathrm{C}_{6} \mathrm{H}_{10}+\mathrm{O}_{3}$ dimer deuteration experiments using $\mathrm{D}_{2} \mathrm{O}$ mostly lead to two hydrogens being exchanged, but also to three and four hydrogen exchanges in the heaviest dimer products observed, consistent with the peroxide structures [i.e., ROOR or $\mathrm{R}(\mathrm{O}) \mathrm{OO}(\mathrm{O}) \mathrm{R})$ ] formed by recombination of two peroxy radicals containing hydroperoxide functionalities. Also the addition of $\mathrm{D}_{2} \mathrm{O}$ to the $\mathrm{C}_{6} \mathrm{D}_{10}+\mathrm{O}_{3}$ system provided valuable information: the deuterated dimers had exchanged their labile deuteriums to hydrogens prior to detection, but by adding $\mathrm{D}_{2} \mathrm{O}$ to the bath gas flow these hydrogens were observed to exchange back to deuteriums. In this way it was found that the deuterated dimers contained one to three exchangeable hydrogens, which is less than what was observed for the $\mathrm{C}_{6} \mathrm{H}_{10}+\mathrm{O}_{3}$ case.

The two most intense dimer peaks detected in the $\mathrm{C}_{6} \mathrm{D}_{10}+\mathrm{O}_{3}$ reaction were $\mathrm{C}_{12} \mathrm{D}_{18} \mathrm{H}_{2} \mathrm{O}_{7} \mathrm{NO}_{3}{ }^{-}$(356.2223 Th) and $\mathrm{C}_{12} \mathrm{D}_{16} \mathrm{H}_{2} \mathrm{O}_{10} \mathrm{NO}_{3}{ }^{-}$(400.1788 Th) (Table 1). Note that the $\mathrm{C}_{12} \mathrm{D}_{18} \mathrm{H}_{2} \mathrm{O}_{7} \mathrm{NO}_{3}{ }^{-}$product has altogether $20 \mathrm{H}+$ $\mathrm{D}$ atoms and indicates interference by $\mathrm{OH}$ chemistry, as explained above. The deuterated dimers exchanged fewer hydrogens than the non-deuterated dimers, which is exactly what is expected when comparing reaction products that have been formed by hydrogen vs deuterium -shift reactions. Less hydroperoxide functionalities are effectively formed through the slower D-shift reactions. However, it is not certain that the $\mathrm{NO}_{3}{ }^{-}$will cluster in exactly the same way with the deuterated ELVOC as with the non-deuterated ELVOC molecules, although there is currently no reason to suspect otherwise.

It's also worth emphasizing that the dimers have on average higher $\mathrm{H} / \mathrm{C}$ (or $\mathrm{D} / \mathrm{C}$ ) than the monomers, which indicates that their formation is in competition with the unimolecular termination pathways (i.e., ejecting $\mathrm{OH}$ and $\mathrm{HO}_{2}$ radicals) forming the monomer compounds. 


\section{S1.7. cis-6-nonenal ozonolysis}

Cis-6-nonenal ozonolysis produces a similar Criegee Intermediate as the cyclohexene ozonolysis (CI 1 in Scheme S1 and CI in Scheme 1, respectively), albeit with different internal excitation and lesser yield due to the concomitant formation of another type of three carbon Criegee Intermediate (CI 2 in scheme S1). The cis-6-nonenal ozonolysis was observed to lead to a similar monomer ELVOC distribution as the cyclohexene ozonolysis (Figure 1a and Figure 3c), consistent with the proposed formation mechanism.

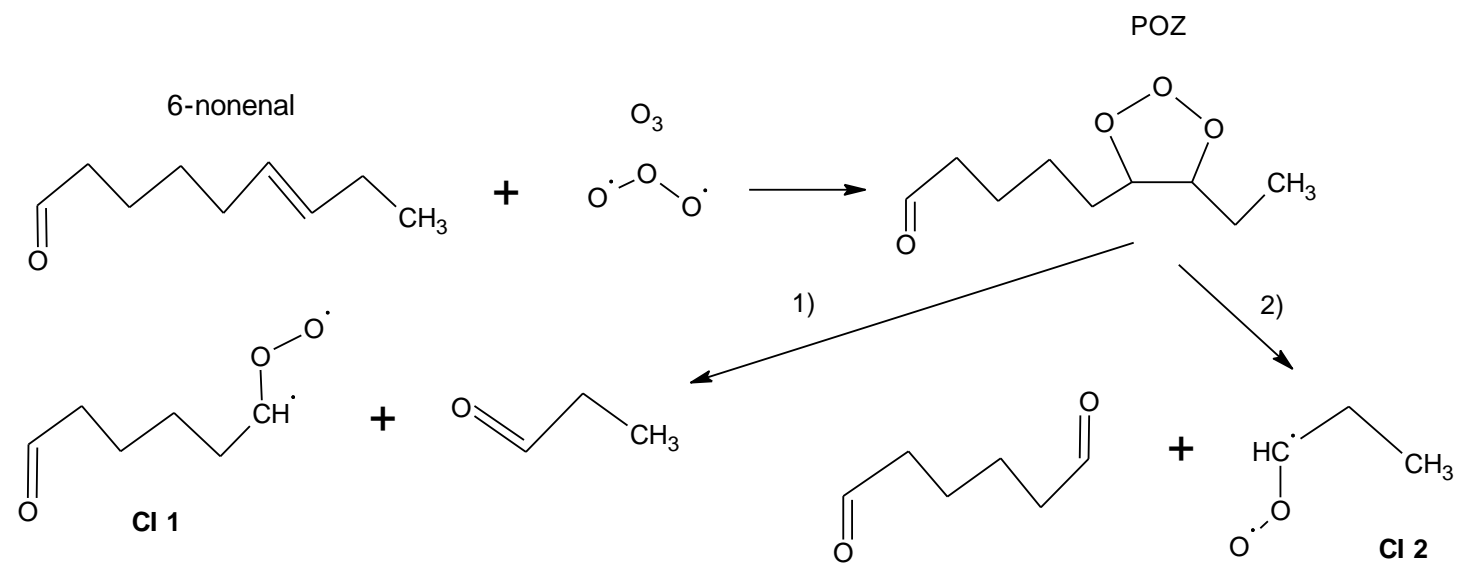

Scheme S1 cis-6-nonenal ozonolysis leads to two different Criegee intermediates CI 1 and CI 2, through $\mathrm{O}_{3}$ addition, primary ozonide (POZ) formation and decomposition.

The nonenal ELVOC deuteration experiments did not yield a quantitative H/D exchange as can be seen in Figure S4. Most likely the residual $\mathrm{H}_{2} \mathrm{O}$ in the system prevented from obtaining a complete H/D exchange. Another explanation could be the formation of isomers with different functional groups that are not able to exchange hydrogens. However, the charger nitrate ion distribution presented in Figure S4c, which experiences the same incomplete $\mathrm{H} / \mathrm{D}$ exchange, indicates that there are still plenty labile $\mathrm{H}$ atoms in the system (probably due to residual $\mathrm{H}_{2} \mathrm{O}$ ) capable of exchanging $\mathrm{D}$ to $\mathrm{H}$, and thus explains the observed product distribution. 

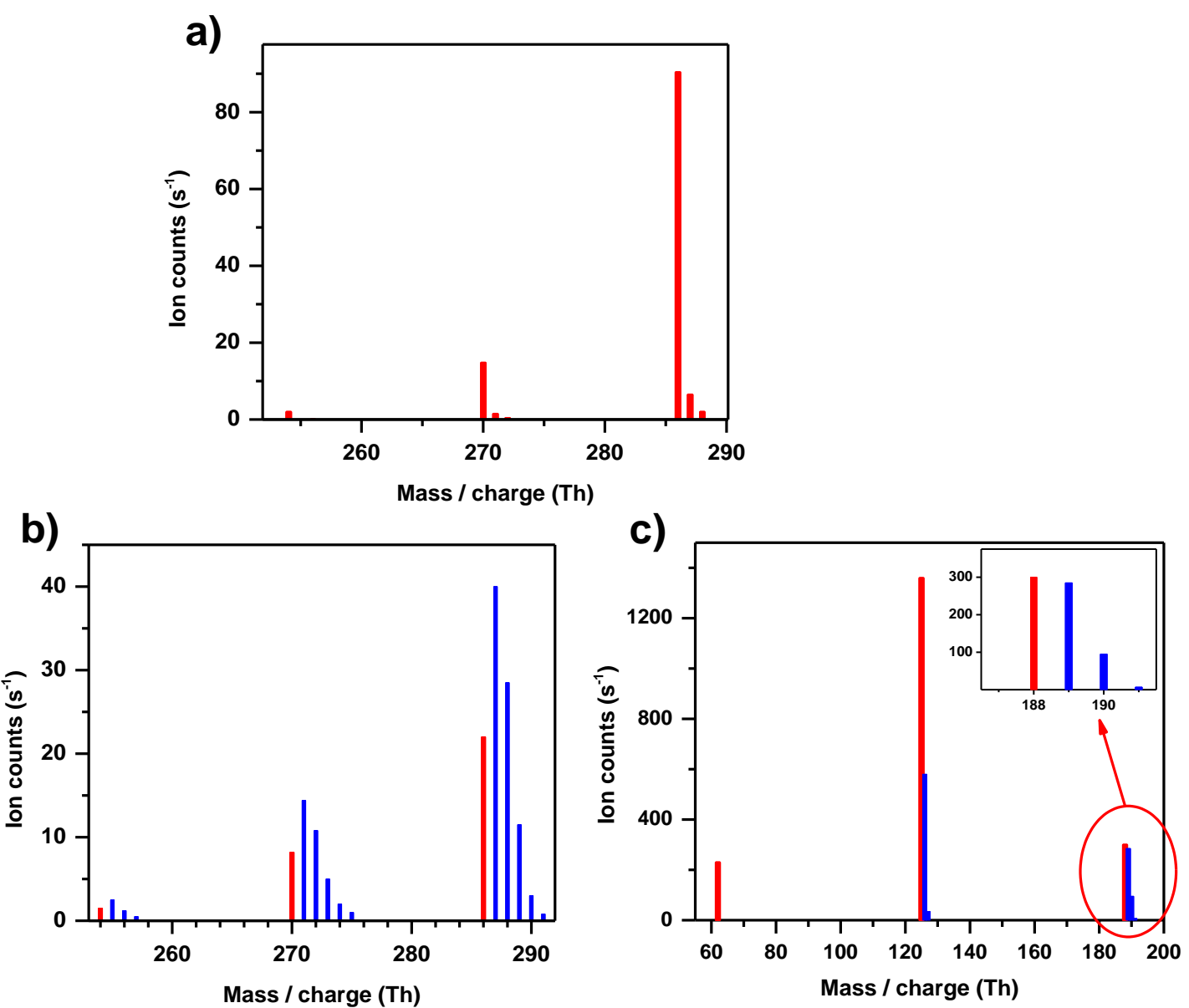

Figure S4a-S4c ELVOC spectra from cis-6-nonenal experiments. a) cis-6-nonenal ozonolysis ELVOC spectrum (Figure $3 \mathrm{c}$ in manuscript text) and b) the same nonenal ELVOCs after adding $\mathrm{D}_{2} \mathrm{O}$ to the gas mixture. c) Charger nitrate ion clusters also exchange their acidic hydrogens, i.e., $\mathrm{HNO}_{3} * \mathrm{NO}_{3}{ }^{-} \rightarrow \mathrm{DNO}_{3} * \mathrm{NO}_{3}{ }^{-}$and $\left(\mathrm{HNO}_{3}\right)_{2} * \mathrm{NO}_{3}{ }^{-} \rightarrow$ $\mathrm{HNO}_{3} \mathrm{DNO}_{3} * \mathrm{NO}_{3}{ }^{-},\left(\mathrm{DNO}_{3}\right)_{2} * \mathrm{NO}_{3}{ }^{-}$; the inset in the upper right corner shows the incomplete $\mathrm{H} / \mathrm{D}$-exchange of the nitrate trimer charger ion. Blue color indicates peaks with D atoms.

\section{S1.8. ELVOC molar yield}

The detection efficiency of the nitrate CI-APi-TOF to ELVOC was very recently estimated to be similar to the detection efficiency of $\mathrm{H}_{2} \mathrm{SO}_{4}{ }^{12}$, and thus we used a calibration factor obtained for $\mathrm{H}_{2} \mathrm{SO}_{4}$ to convert the measured ion signals into concentrations. Hence, the CI-APi-TOF was calibrated by generating a known amount of $\mathrm{H}_{2} \mathrm{SO}_{4}$ from a $\mathrm{SO}_{2}+\mathrm{OH}\left(+\mathrm{O}_{2}+\mathrm{H}_{2} \mathrm{O}\right)$ reaction ${ }^{91}$; OH-radicals were photochemically produced and the $\mathrm{H}_{2} \mathrm{SO}_{4}$ subsequently formed is readily measured by the nitrate CI-APi-TOF ${ }^{62}$. The calibration resulted in a factor of $\mathrm{C}_{\mathrm{H} 2 \mathrm{SO} 4}=1.94 \times 10^{10}$ molecule $\mathrm{cm}^{-3}$. 
In addition to the calibration factor, one needs to take into account the amount of available charge carriers able to transfer the charge to the target species. In practice this was done by normalizing the product ion signals obtained by the amount of principal charge carriers \{ nitrate ion $\left(\mathrm{NO}_{3}{ }^{-}\right)$and its dimer $\left(\mathrm{HNO}_{3} * \mathrm{NO}_{3}{ }^{-}\right)$ and trimer $\left.\left[\left(\mathrm{HNO}_{3}\right)_{2} * \mathrm{NO}_{3}{ }^{-}\right]\right\}$in the gas mixture. With these procedures one arrives at an equation (eq.S1) for individual ELVOC concentration:

$[E L V O C]=C_{H 2 S O 4} \times \frac{\left[\mathrm{ELVOCxNO}_{3}^{-}\right]}{\left[\mathrm{NO}_{3}^{-}\right]+\left[\mathrm{HNO}_{3} \mathrm{NO}_{3}^{-}\right]+\left[\left(\mathrm{HNO}_{3}\right) 2 \mathrm{NO}_{3}^{-}\right]}$

The yield measurements were performed under pseudo-steady-state conditions, i.e., under conditions where the observed ELVOC signals remain effectively constant for as long as the experimental conditions remain unchanged in the flow reactor system, e.g., from several minutes to up to an hour in comparison with 4 to 20 $\mathrm{s}$ residence time in the flow tube (see Figure S2 and S3). This was accomplished by adjusting the reagent concentrations in the gas flow and letting the system relax into a balance where the observed rate of change of the gas composition was zero. For cyclohexene ELVOCs, under these conditions, the production term is equal to the cyclohexene ozonolysis rate i.e., $k_{\mathrm{C} 6 \mathrm{H} 10+\mathrm{O} 3} \times\left[\mathrm{O}_{3}\right][\mathrm{CH}]$, corrected by the ELVOC molar yield $\left.\left(\mathrm{Y}_{\mathrm{ELVOC}}\right)\right\}$ and the loss happens by wall reaction, but potentially also by other ways not easily separable from the experimental data. For practical purposes, the loss processes can be grouped under a common first-order loss rate $\left(k_{\text {LOss }}\right)$, provided the yield measurements are performed under conditions where the observed ELVOC yield is first-order with respect to the production term. The pseudo-steady-state can then be presented as:

$\mathrm{d}[\mathrm{ELVOC}] / \mathrm{d} t=k_{\mathrm{C} 6 \mathrm{H} 10+\mathrm{O} 3} \times \mathrm{Y}_{\mathrm{ELVOC}} \times\left[\mathrm{O}_{3}\right][\mathrm{CH}]-k_{\mathrm{LOSS}} \times[\mathrm{ELVOC}] \approx 0$

As ELVOCs have by definition a very low vapor pressure, their wall losses in a flow tube are expected to be substantial. Fortunately, their extremely low vapor pressures also mean that no significant re-evaporation of the ELVOC is expected. In order to estimate the fraction of ELVOCs lost to the walls of the flow tube, a diffusion limited first-order wall loss rate $\left(k_{\mathrm{WALL}}=3.65 \mathrm{D} / \mathrm{r}^{2}\right.$, where $r$ is the radius of the flow reactor $)$ was calculated by applying a similar ELVOC diffusion constant as used by Ehn et al. ${ }^{12}$ for $\alpha$-pinene derived ELVOCs $\left(D=0.05 \mathrm{~cm}^{2} \mathrm{~s}^{-1}\right)$. The normalized and calibrated ion counts obtained for the ELVOC were then corrected by the calculated wall loss fraction and the final yield determined with:

$\mathrm{Y}_{\mathrm{ELVOC}}=\left(k_{\mathrm{LOSS}} \times[\mathrm{ELVOC}]\right) /\left(k_{\mathrm{C} 6 \mathrm{H} 10+\mathrm{O} 3} \times\left[\mathrm{O}_{3}\right][\mathrm{CH}]\right)$

where $k_{\mathrm{C} 6 \mathrm{H} 10+\mathrm{O} 3}=7.4 \times 10^{-17} \mathrm{~cm}^{3}$ molecule $\mathrm{e}^{-1} \mathrm{~s}^{-1}$ was taken from the most recent determination ${ }^{33}$. Only the peaks with identified elemental compositions were included in the ELVOC yield calculations (Table 1), and 
hence, the quoted value is a lower limit for the ELVOC yield from cyclohexene ozonolysis system. Nevertheless, even by inspection of Figure 1a it's clear that these peaks contain most of the product ELVOCs and by omitting a part of the lower intensity peaks is not expected to lead to a large error, probably at most around $10 \%$ of the determined value.

The yield of ELVOCs is seen to increase together with the product of [cyclohexene] and $\left[\mathrm{O}_{3}\right]$ as expected ${ }^{12}$ (Figure 4), and the yield determined for the $\mathrm{C}_{6} \mathrm{H}_{10}+\mathrm{O}_{3}$ reaction system was $(4.5 \pm 0.2) \%$, with the uncertainty reported as one standard error of the fit. The overall uncertainty of this value was estimated as $\pm 80 \%$, and was obtained by the propagation of error method. It should be stressed that the yield determined in this work corresponds only to a few percent of the total product yield and does not seek to explain the formation of already well-established major products of the reaction given in previous publications ${ }^{29-57}$.

\section{S1.9. Relation to previous studies}

Due to its structural similarity with the biogenic monoterpenes the cyclohexene ozonolysis system has attracted considerable attention. It has been a model system for deriving ozonolysis mechanisms and gaining insight into ambient SOA formation processes ${ }^{33,35,49,52-54}$. The major products of the $\mathrm{C}_{6} \mathrm{H}_{10}+\mathrm{O}_{3}$ reaction have been obtained previously, with various acids, diacids and oxo-acids identified in the gas- and particle phases, for example, adipic and glutaric acids have been frequently cited ${ }^{33,34,49,51,52,56,57}$. The OH-yield of cyclohexene $+\mathrm{O}_{3}$ reaction has been determined most recently as $0.47^{33}$ with only a small difference in the yield measured for the $\mathrm{C}_{6} \mathrm{D}_{10}+\mathrm{O}_{3}$ reaction; OD yield of $0.50^{29}$.

The role of radical chemistry in controlling the product distributions in cyclohexene SOA formation was emphasized by Keywood and co-workers ${ }^{31}$. They provided evidence on the role of acyl peroxy radical [i.e., -O-O-C(=O)-R] reactions, which had already previously been suggested to participate in SOA formation ${ }^{31,92}$. In the current work, acyl peroxy radicals are seen to be important in ELVOC formation too (Scheme 2). However, acyl radical reactions (i.e., precursors for acyl peroxy radicals) lead to various different types of products as well, for example, they're known to be prone to dissociation by losing a CO fragment ${ }^{20,33,88}$, which is the reason for $\mathrm{C}_{11}$-compounds detected in the dimer product distribution (see discussion above). Acyl peroxy radical recombination, on the other hand, leads to diacyl peroxides, which Ziemann ${ }^{32}$ suggested as important low volatility nucleating agents in the oxidation of cyclohexene. Nevertheless, the channels leading to ELVOCs have low yields ${ }^{12}$, and only a small part of the produced acyl radicals will transform into ELVOCs. Müller et al. ${ }^{55}$ found ester products as the possible oligomerizing, and hence, nucleating agents in cyclohexene ozonolysis, but concluded that other products could be contributing too. 
Warren et al. ${ }^{42}$ observed an increase in cyclohexene SOA yield under humid conditions and attributed this to an increase in aldehyde formation by a $\mathrm{SCI}+\mathrm{H}_{2} \mathrm{O}$ reaction. In this work, we see no influence of $\mathrm{H}_{2} \mathrm{O}$ to the ELVOC spectrum obtained, and hence, this increase does not seem to result from ELVOCs reacting. In addition, Müller et al. ${ }^{55}$ saw no relative humidity (RH) dependence on product formation. Moreover, according to the most recent previous studies ${ }^{30,36}$ the cyclohexene ozonolysis should not produce a stabilized Criegee intermediate and thus should not react appreciably with water in this system due to its very short lifetime. In a study by Carlsson et al. ${ }^{33}$ it was observed that the presence of $\mathrm{SO}_{2}$ in the cyclohexene ozonolysis gas mixture greatly enhanced particle formation through $\mathrm{H}_{2} \mathrm{SO}_{4}$ production and they pointed out that the SOA formation in the cyclohexene ozonolysis system is due to "chemical activation driven dynamics in the vinylhydroperoxide channel", which is exactly what is inferred from the results of this study too.

Tantamount to the mechanism proposed in this work is the formation of peroxy radicals $\left(\mathrm{RO}_{2}\right)$ by $\mathrm{O}_{2}$ addition to the carbon centered radicals formed in the hydrogen shift step. While $\mathrm{RO}_{2}$ radicals have not generally been observed to react with $\mathrm{O}_{2}$, the carbon-centered alkyl radicals (R) will be converted to peroxy radicals $\left(\mathrm{R}+\mathrm{O}_{2} \rightarrow \mathrm{RO}_{2}\right.$ ) practically instantly in ambient air. Alkyl radicals are known to react with a wide variety of species, while $\mathrm{RO}_{2}$ mainly react with $\mathrm{NO}, \mathrm{HO}_{2}$ and $\mathrm{RO}_{2}{ }^{82,88}$. Due to the $\mathrm{RO}_{2}$ reacting with only a few species, the probability of $\mathrm{RO}_{2}$ unimolecular reactions (isomerization and fragmentation) significantly increases $^{93}$, especially under pristine atmospheric conditions where $[\mathrm{NO}]$ is low.

The arguments previously found to hold for 1 , $\mathrm{x}$ hydrogen shifts seem to be valid for the ELVOC formation too, e.g., close-by oxygenated functional groups catalyze the process but abstraction from the neighboring carbon atom is generally forbidden due to high ring strain in the transition state ${ }^{17,19,94,95}$. Thus the hydrogen abstractions will most likely occur in places where the hydrogens are weaker bonded due to the electron withdrawing inductive effects of properly situated functional groups. For example, oxygenated groups such as hydroperoxy, carbonyl or hydroxyl in the $\alpha$-carbon have been observed to lower the $\mathrm{H}$-abstraction barriers significantly ${ }^{19,}{ }^{94}$. In line with this, the aldehydic hydrogens (i.e., H-atoms in terminal -CHO groups) are generally rather weakly bound and often the easiest to abstract. It is these relatively weak $\mathrm{C}-\mathrm{H}$ bonds that facilitate the peroxy radical isomerization to a hydroperoxide (commonly noted: $\mathrm{RO}_{2} \rightarrow \mathrm{QOOH}$ ) even at room temperature; a reaction class extensively investigated in combustion ${ }^{14,96}$. However, the $\mathrm{RO}_{2}$ isomerization is also in competition with a route leading to $\mathrm{HO}_{2}$ elimination, and the $\mathrm{HO}_{2}$ yield has been observed to increase and shift to lower temperatures when the carbon skeleton lengthens ${ }^{16,88}$.

Ultimately, the formation of ELVOC from cyclohexene seems to be governed by the amount of abstractable hydrogen atoms in the carbon skeleton, which are loosened from the backbone by the presence of nearby oxygenated functional groups. The proposed chain like mechanism starting from ozonolysis leads to the generation of an additional OH-radical on top of the VHP decomposition, and may thus explain, in part, 
some of the discrepancy observed in the heightened $\mathrm{OH}-$ levels over specific forested environments dominated by biogenic emissions ${ }^{94,97,98}$. The proposed mechanism offers another type of explanation without invoking the recycling mechanisms ${ }^{94,98-101}$, which likely run in parallel to the reaction sequences described in the current paper. The mechanism presented here is strictly valid only for cyclohexene ozonolysis, but similar reaction sequences can be expected to happen in different alkene ozonolysis reactions. For example, in monoterpene oxidation by $\mathrm{O}_{3}$ for which $\mathrm{C}_{6} \mathrm{H}_{10}+\mathrm{O}_{3}$ can be considered a surrogate reaction.

\section{S2. Quantum chemical calculations}

\section{S2.1. Validation of configurational sampling algorithm}

For the 1,7 hydrogen shift and CO loss reactions of $\mathrm{C}_{6} \mathrm{H}_{9} \mathrm{O}_{4}$, the ROHF-RCCSD(T)-F12a/VDZ-F12 energy was calculated for every reactant, transition state (TS) and product conformer (over 100 conformers in total) in order to test the validity of the sampling method. While the absolute reaction energetics (e.g., energy difference between transition states and reactants, or reactants and products) predicted by the different methods differed significantly (by several $\mathrm{kcal} / \mathrm{mol}$ ), the relative energies of different conformers of the same system (i.e., different torsional conformers of the same reactant, TS or product) were close to each other. The relative energy is here defined as the energy of a conformer minus that of the lowest-energy conformer of the same type (reactant, TS or product).

The average unsigned difference between the $\omega$ B97XD/aug-cc-pVTZ and ROHF-RCCSD(T)-F12a/VDZF12 relative energies were $0.24,0.44,0.08$ and $0.08 \mathrm{kcal} / \mathrm{mol}$ for the reactants, H-shift transition states, products and $\mathrm{CO}$ loss transition states, respectively. The largest difference observed was $0.80 \mathrm{kcal} / \mathrm{mol}$, for one of the $\mathrm{H}$-shift transition states. Even more encouragingly, despite the total number of conformers exceeding 100, both methods predicted the same conformer to have the lowest energy for all four systems (reactant, product and two transition states).

Also the B3LYP/6-31+G(d) relative energies (of the B3LYP-optimized structures) were surprisingly close to the final ROHF-RCCSD(T)-F12a/VDZ-F12 values, with average unsigned differences of $0.39,0.58,0.74$ and $0.20 \mathrm{kcal} / \mathrm{mol}$ for the reactants, $\mathrm{H}$-shift transition states, products and $\mathrm{CO}$ loss transition states, respectively. The largest difference observed between B3LYP and $\operatorname{CCSD}(\mathrm{T})$ relative electronic energies was $1.55 \mathrm{kcal} / \mathrm{mol}$, for one of the reactant structures. This suggests that picking the structures within $2 \mathrm{kcal} / \mathrm{mol}$ of the minimum at the B3LYP/6-31+G(d) level for further calculations is a reasonable strategy for finding

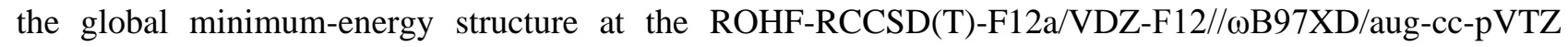
level. 
Table S2 shows the partition functions obtained using only the lowest-energy conformer, or all the conformers included. Table S3 shows the rate coefficients obtained using only the lowest-energy conformers (as in conventional TST), and using MC-TST.

Table S2 The partition functions of the reactants, transition states and products for each reaction.

\begin{tabular}{|c|c|c|c|c|c|c|}
\hline \multirow[b]{2}{*}{ Label } & \multicolumn{3}{|c|}{ Lowest-energy conformer $^{a}$} & \multicolumn{3}{|c|}{ Including all conformers $^{b}$} \\
\hline & $\mathrm{Q}_{\mathrm{R}}$ & $\mathrm{Q}_{\mathrm{TS}}$ & $\mathrm{Q}_{\mathrm{P}}$ & $\mathrm{Q}_{\mathrm{R}}$ & $\mathrm{Q}_{\mathrm{TS}}$ & $\mathrm{Q}_{\mathrm{P}}$ \\
\hline $\begin{array}{l}\mathrm{C}_{6} \mathrm{H}_{9} \mathrm{O}_{4} 1,7 \\
\text { H-shift }\end{array}$ & $1.4 \times 10^{10}$ & $4.5 \times 10^{8}$ & $1.7 \times 10^{9}$ & $1.6 \times 10^{11}$ & $1.2 \times 10^{9}$ & $6.5 \times 10^{10}$ \\
\hline $\begin{array}{l}\mathrm{C}_{6} \mathrm{H}_{9} \mathrm{O}_{4} \\
\mathrm{CO} \text { loss }\end{array}$ & $1.7 \times 10^{9}$ & $1.6 \times 10^{10}$ & - & $6.5 \times 10^{10}$ & $1.5 \times 10^{11}$ & - \\
\hline $\begin{array}{l}\mathrm{C}_{6} \mathrm{H}_{9} \mathrm{O}_{6} 1,8 \\
\text { H-shift }\end{array}$ & $2.6 \times 10^{10}$ & $4.1 \times 10^{9}$ & $2.1 \times 10^{11}$ & $2.6 \times 10^{10}$ & $9.5 \times 10^{9}$ & $3.1 \times 10^{12}$ \\
\hline $\begin{array}{l}\mathrm{C}_{6} \mathrm{H}_{9} \mathrm{O}_{6} 1,7 \\
\text { H-shift }\end{array}$ & $2.6 \times 10^{10}$ & $2.7 \times 10^{9}$ & $9.9 \times 10^{10}$ & $2.6 \times 10^{11}$ & $7.0 \times 10^{9}$ & $1.5 \times 10^{11}$ \\
\hline $\begin{array}{l}\mathrm{C}_{6} \mathrm{H}_{9} \mathrm{O}_{6} \\
\mathrm{CO} \text { loss }\end{array}$ & $2.1 \times 10^{11}$ & $7.8 \times 10^{10}$ & - & $3.1 \times 10^{12}$ & $1.5 \times 10^{13}$ & - \\
\hline $\begin{array}{l}\mathrm{C}_{6} \mathrm{H}_{9} \mathrm{O}_{8} 1,7 \\
\text { H-shift }\end{array}$ & $2.3 \times 10^{12}$ & $1.5 \times 10^{11}$ & $2.6 \times 10^{12}$ & $5.4 \times 10^{13}$ & $1.9 \times 10^{11}$ & $4.6 \times 10^{13}$ \\
\hline $\begin{array}{l}\mathrm{C}_{6} \mathrm{H}_{9} \mathrm{O}_{8} 1,4 \\
\text { H-shift }\end{array}$ & $2.3 \times 10^{12}$ & $5.9 \times 10^{11}$ & - & $5.4 \times 10^{13}$ & $2.5 \times 10^{13}$ & - \\
\hline $\begin{array}{l}\mathrm{C}_{6} \mathrm{H}_{9} \mathrm{O}_{8} 1,5 \\
\mathrm{H} \text {-shift }\end{array}$ & $2.3 \times 10^{12}$ & $6.4 \times 10^{11}$ & - & $5.4 \times 10^{13}$ & $1.1 \times 10^{12}$ & - \\
\hline $\begin{array}{l}\mathrm{C}_{6} \mathrm{H}_{9} \mathrm{O}_{8} \quad 1,6 \\
\text { H-shift }\end{array}$ & $2.3 \times 10^{12}$ & $4.8 \times 10^{11}$ & $4.4 \times 10^{11}$ & $5.4 \times 10^{13}$ & $1.4 \times 10^{12}$ & $3.9 \times 10^{13}$ \\
\hline
\end{tabular}

${ }^{a}$ The partition function of the lowest energy conformer (Q), and, ${ }^{b}$ the partition function using all conformers of the reactant $(\mathrm{R})$, transition state (TS) and product $(\mathrm{P})$ for each reaction. The partition function is a product of the rotational and vibrational partition function. The ratios of $\mathrm{Q}_{\text {elec }}$ and $\mathrm{Q}_{\text {trans }}$ are assumed to be equal to 1 for all reaction steps studied here, and therefore cancel out in the rate coefficient calculations. Note that the reactant of the $\mathrm{CO}$ loss reaction is the same as the product of one of the $\mathrm{H}$-shift reactions. 
Table S3 Calculated rate coefficients for the different H-shift and CO loss reactions.

\begin{tabular}{|c|c|c|c|c|c|c|c|}
\hline & Barriers & cal/mol) & $k_{\mathrm{TST}}$ & $\left.\mathrm{s}^{-1}\right)^{a}$ & $k_{\mathrm{MC}}$ & $\left(\mathrm{s}^{-1}\right)^{a}$ & \\
\hline Reaction & Forward & Reverse & Forward & Reverse & Forward & Reverse & $\kappa$ (tunneling) \\
\hline $\begin{array}{ll}\mathrm{C}_{6} \mathrm{H}_{9} \mathrm{O}_{4} & 1,7 \\
\text { H-shift } & \end{array}$ & 15.6 & 14.7 & $7.9 \times 10^{-1}$ & 29 & $1.7 \times 10^{-1}$ & 2.0 & 44 \\
\hline $\begin{array}{ll}\mathrm{C}_{6} \mathrm{D}_{9} \mathrm{O}_{4} & 1,7 \\
\text { D-shift } & \end{array}$ & 16.3 & 15.7 & $1.9 \times 10^{-1}$ & 4.4 & - & - & 6.4 \\
\hline $\begin{array}{ll}\mathrm{C}_{6} \mathrm{H}_{9} \mathrm{O}_{4} & \mathrm{CO} \\
\text { loss } & \end{array}$ & 14.2 & & $2.2 \times 10^{3}$ & - & $5.1 \times 10^{2}$ & - & - \\
\hline $\begin{array}{ll}\mathrm{C}_{6} \mathrm{H}_{9} \mathrm{O}_{6} & 1,8 \\
\text { H-shift } & \end{array}$ & 18.0 & 24.2 & $6.5 \times 10^{-2}$ & $2.4 \times 10^{-7}$ & $1.5 \times 10^{-2}$ & $3.8 \times 10^{-8}$ & 33 \\
\hline $\begin{array}{ll}\mathrm{C}_{6} \mathrm{D}_{9} \mathrm{O}_{6} & 1,8 \\
\text { D-shift } & \end{array}$ & 18.7 & 25.2 & $1.6 \times 10^{-2}$ & $3.8 \times 10^{-8}$ & - & - & 5.1 \\
\hline $\begin{array}{ll}\mathrm{C}_{6} \mathrm{H}_{9} \mathrm{O}_{6} & 1,7 \\
\text { H-shift } & \end{array}$ & 16.7 & 29.8 & $3.7 \times 10^{-1}$ & $\begin{array}{l}2.3 \times 10^{-} \\
11\end{array}$ & $9.7 \times 10^{-2}$ & $4.0 \times 10^{-11}$ & 39 \\
\hline $\begin{array}{ll}\mathrm{C}_{6} \mathrm{H}_{9} \mathrm{O}_{6} & \mathrm{CO} \\
\text { loss } & \end{array}$ & 9.5 & & $2.4 \times 10^{5}$ & - & $3.3 \times 10^{6}$ & - & - \\
\hline $\begin{array}{ll}\mathrm{C}_{6} \mathrm{H}_{9} \mathrm{O}_{8} & 1,7 \\
\text { H-shift } & \end{array}$ & 19.9 & 22.8 & $1.2 \times 10^{-3}$ & $7.1 \times 10^{-6}$ & $6.2 \times 10^{-5}$ & $5.2 \times 10^{-7}$ & 723 \\
\hline $\begin{array}{ll}\mathrm{C}_{6} \mathrm{D}_{9} \mathrm{O}_{8} & 1,7 \\
\text { D-shift } & \end{array}$ & 21.0 & 23.8 & $1.5 \times 10^{-4}$ & $1.1 \times 10^{-6}$ & - & - & 22 \\
\hline $\begin{array}{ll}\mathrm{C}_{6} \mathrm{H}_{9} \mathrm{O}_{8} & 1,4 \\
\text { H-shift } & \end{array}$ & 22.4 & - & $6.5 \times 10^{-5}$ & - & $1.1 \times 10^{-4}$ & - & $\approx 10^{\mathrm{b}}$ \\
\hline $\begin{array}{ll}\mathrm{C}_{6} \mathrm{H}_{9} \mathrm{O}_{8} & 1,5 \\
\text { H-shift } & \end{array}$ & 21.0 & - & $7.6 \times 10^{-4}$ & - & $5.7 \times 10^{-5}$ & - & - \\
\hline $\begin{array}{ll}\mathrm{C}_{6} \mathrm{H}_{9} \mathrm{O}_{8} & 1,6 \\
\text { H-shift } & \end{array}$ & 19.8 & 18.4 & $4.2 \times 10^{-3}$ & $2.2 \times 10^{-1}$ & $5.2 \times 10^{-4}$ & $7.1 \times 10^{-3}$ & 200 \\
\hline
\end{tabular}

${ }^{a}$ Note that rates do not include tunneling corrections. ${ }^{b}$ The exact Eckart tunneling factor could not be completed due to the lack of data on the reverse barrier; test calculations varying the reverse barrier in a wide range between 10 and $50 \mathrm{kcal} / \mathrm{mol}$ indicate that the tunneling factor is very likely between 8 and 12 . 
We evaluated the effect of hindered rotations on the rate coefficients using the hindered rotor module of the Gaussian 09 program suite ${ }^{77-80}$. Specifically, we ran a hindered rotor frequency calculation for all the reactants, transition states and products with the lowest zero-point corrected energy. However, for many of these structures, the program was unable to find a one-to-one correspondence between vibrational and internal rotation modes, and thus did not calculate hindered rotor-corrected partition functions, energies, entropies or other thermodynamic parameters. Closer inspection revealed that the problem occurred for all transition states, and also for some (though not all) of the reactants and products containing internal hydrogen bonds, which may partially constrain the internal rotations.

In order to qualitatively assess the effect of hindered rotations on the reaction energetics, we did the following. For the reactants and products for which the hindered rotor module worked on the lowest-energy conformer (specifically, the $\mathrm{C}_{6} \mathrm{H}_{9} \mathrm{O}_{4}$ reactant and product and the $\mathrm{C}_{6} \mathrm{H}_{9} \mathrm{O}_{6}$ product), we used the values from those calculations. For the $\mathrm{C}_{6} \mathrm{H}_{9} \mathrm{O}_{6}$ reactant and the $\mathrm{C}_{6} \mathrm{H}_{9} \mathrm{O}_{8} 1,7 \mathrm{H}$-shift reactant and product (for which the hindered rotor module failed), we constructed a new set of conformers, where the six carbon atoms were arranged linearly (i.e., the carbon chain did not loop back on itself), and the $\mathrm{OOH}$ groups were oriented so that no ring structures with hydrogen bonds could form. These conformers were naturally higher in energy than the respective minimum-energy conformers, and were only used for assessing the effect of internal rotations. For these systems, the hindered rotor module was able to calculate the desired corrections to thermodynamic parameters. Altogether, this resulted in a set of 49 identified hindered rotation modes (from the six studied molecules), for which average thermodynamic parameters could then be calculated.

The main effect of hindered rotations on the thermodynamic parameters is to increase the entropy, and thereby decrease the free energy. Hindered rotations also have a small effect on the thermal energy (including zero-point energy corrections), but this is not systematic - the energy can both increase and decrease. According to the results of the hindered rotor module, each hindered rotation increases the entropy by between about 0.06 and $0.46 \mathrm{cal} / \mathrm{K} \mathrm{mol}$, with an average value of $0.28 \mathrm{cal} / \mathrm{K} \mathrm{mol}$, and changes the thermal energy by between -0.05 and $+0.064 \mathrm{kcal} / \mathrm{mol}$, with an average value of $+0.033 \mathrm{kcal} / \mathrm{mol}$. These together change the Gibbs free energy (at $298.15 \mathrm{~K}$ ) by $-0.05 \mathrm{kcal} / \mathrm{mol}$ per torsional mode. These values correspond to the McClurg treatments; the model by Pitzer \& Gwinn yields essentially identical results while that by Truhlar consistently predicts smaller effects. We used these average values to qualitatively assess the effect of hindered rotations on the rate coefficients. It should be noted that the Gaussian program also reports an entropic effect from the so-called "multiplicity" of the hindered rotations, i.e., the fact that some internal rotations connect multiple accessible minima. This effect is already accounted for via the conformational sampling in the MC-TST rate coefficients (see section S2.2.), and is therefore not included in this calculation. 
Since the products of hydrogen shift reactions have one more torsional angle than the reactants (due to the new $\mathrm{OOH}$ group), accounting for hindered rotations thus slightly increases the thermodynamic favorability of the hydrogen shift reactions (an entropy difference of $0.28 \mathrm{cal} / \mathrm{K}$ mol corresponds to an increase in the equilibrium constant of about 15 percent at $298 \mathrm{~K}$ ). The increase in thermal energy acts in the opposite direction, but the magnitude of this effect is less than half of the entropic effect; about 6 percent. Compared to the other error sources in our calculations, the hindered rotor effect on the equilibrium constants is thus negligible.

Due to the constraints imposed by the reacting $\mathrm{C}-\mathrm{H} . . . \mathrm{O}-\mathrm{O}$ groups, the hydrogen shift transition states have a smaller number of internal rotation degrees of freedom than the reactants and products. The net effect of the internal rotations is thus to lower both the forward and reverse rate coefficients. The magnitude of this effect depends on both the number of internal rotations in the reactants/products, and on the number of rotations constrained by the transition state. For the $1,7 \mathrm{H}$-shift transition state of $\mathrm{C}_{6} \mathrm{H}_{9} \mathrm{O}_{4}$, and the 1,8 $\mathrm{H}$-shift transition state of $\mathrm{C}_{6} \mathrm{H}_{9} \mathrm{O}_{6}$, all but one of the internal rotations are constrained (see Figs $\mathrm{S} 5$ and S6). As discussed above, the combined entropic and energetic effects imply that one hindered rotation mode present in the reactant but not the transition state decreases the forward rate coefficient by approximately a factor of 1.09. Thus, the $1,7 \mathrm{H}$-shift of $\mathrm{C}_{6} \mathrm{H}_{9} \mathrm{O}_{4}$ and the $1,8 \mathrm{H}$-shift of $\mathrm{C}_{6} \mathrm{H}_{9} \mathrm{O}_{6}$ are slowed down by factors of about 1.5 and 1.7, respectively. The $1,7 \mathrm{H}$-shift transition state of $\mathrm{C}_{6} \mathrm{H}_{9} \mathrm{O}_{6}$ (leading to $\mathrm{OH}$ loss) has one more internal rotation degree of freedom compared to the competing 1,8 $\mathrm{H}$-shift transition state. This implies that the relative rate coefficient of the $1,7 \mathrm{H}$-shift will be further increased by a factor of 1.09 due to internal rotor effects. This does not change the qualitative conclusion that the branching ratios of the 1,7 and 1,8 $\mathrm{H}$-shift channels are roughly $90 \%$ and $10 \%$, respectively.

For the $\mathrm{H}$-shift transition states of $\mathrm{C}_{6} \mathrm{H}_{9} \mathrm{O}_{8}$, the number of internal rotations is $8,7,6$ and 5 for the 1,4, 1,5, 1,6 and 1,7 H-shifts, respectively, compared to 10 for the reactant. This corresponds to decreases in the forward rate coefficient ranging from a factor of 1.2 (for the 1,4 H-shift) to 1.5 (for the 1,8 $\mathrm{H}$-shift). The change in relative rates does not change the conclusion that the 1,6 and 1,7 $\mathrm{H}$-shifts form the main channels for the $\mathrm{C}_{6} \mathrm{H}_{9} \mathrm{O}_{8}$ radical.

The CO loss transition states have an equal number of internal rotations compared to their reactants, and the internal rotation corrections therefore largely cancel out.

\section{S2.3.2 Assessing the effect of hindered rotors: MS-T modeling}

Since many of the torsional modes of our molecules are likely strongly coupled to each other, the 1dimensional torsional anharmonicity treatment implemented in the Gaussian Hindered Rotor module is likely 
insufficient to fully model the effect of hindered rotations on the hydrogen shift reactions. Therefore, we performed further calculations using the MS-Tor program ${ }^{80,81}$, which is based on the multistructural approximation with torsional anharmonicity (MS-T) ${ }^{102,103}$. The MS-Tor program is not designed to accept input structures with more than 7 torsional angles, preventing its direct application to our second hydrogen shift step $\mathrm{C}_{6} \mathrm{H}_{9} \mathrm{O}_{6}$ (where the reactant has 8 torsional angles).

We treated the first hydrogen shift step (step 1a in Scheme 2) following the MS-Tor manual. We obtained a value of $+1.1 \mathrm{kcal} / \mathrm{mol}$ for the effect of torsional anharmonicity on the free energy difference between the transition state and reactant at $298.15 \mathrm{~K}$, calculated as the difference between the MS-LH ("multistructural local harmonic") and MS-T free energy values given by the MS-Tor program. This net effect was composed of enthalpy and entropy changes for both the transition state and the reactant. For the $\mathrm{C}_{6} \mathrm{H}_{9} \mathrm{O}_{4}$ reactant, including all six torsions, going from MS-LH to MS-T increased the enthalpy $(\mathrm{H})$ by $0.15 \mathrm{kcal} / \mathrm{mol}$, and decreased the entropy contribution to the free energy (-TS) by $-0.03 \mathrm{kcal} / \mathrm{mol}$. In comparison, the simple uncoupled averaged approach described in section 2.3.1 predicted an enthalpy increase of $0.18 \mathrm{kcal} / \mathrm{mol}$ and a decrease in the entropy contribution of $-0.48 \mathrm{kcal} / \mathrm{mol}$, assuming six torsions in the reactant. For the transition state with one torsion, MS-Tor predicted an enthalpy decrease of $-0.45 \mathrm{kcal} / \mathrm{mol}$, and an increase in the entropy contribution (-TS) of $+1.64 \mathrm{kcal} / \mathrm{mol}$. It is surprising that the effect predicted for the transition state is so much larger than that for the reactant, as the former has only one (non-constrained) torsional degree of freedom, while the latter has six - one of which corresponds to exactly the same rotating group as in the transition state (the terminal CHO group). Closer inspection of the MS-Tor output indicates that its treatment of the transition states may be problematic for our system. For several conformers of the $\mathrm{C}_{6} \mathrm{H}_{9} \mathrm{O}_{4}$ transition state, MS-Tor reported effective torsional barriers of less than $0.01 \mathrm{kcal} / \mathrm{mol}$. In the corresponding reactant structures, the lowest torsional barriers were always above $1 \mathrm{kcal} / \mathrm{mol}$, and usually at least 2 $\mathrm{kcal} / \mathrm{mol}$, even for the same rotating group (i.e. the terminal CHO group). Thus, while the MS-T model is considerably more advanced than the uncoupled model used in Gaussian's Hindered Rotor package, even the MS-Tor results must be considered qualitative for this particular system.

By modifying the program code, we were able to run MS-Tor also for $\mathrm{C}_{6} \mathrm{H}_{9} \mathrm{O}_{6}$, but not $\mathrm{C}_{6} \mathrm{H}_{9} \mathrm{O}_{8}$ (which has 10 torsional angles in the reactant). Treating the $\mathrm{C}_{6} \mathrm{H}_{9} \mathrm{O}_{6}$ reactant required first modifying the program code to accept eight torsional modes as input, running MS-Tor to identify the effective torsional barriers, and then removing one of the torsions as its barrier was too high, leading to non-numerical ("NaN") output values for the MS-T thermodynamic parameters. After these modifications, we finally obtained a value of +0.5 $\mathrm{kcal} / \mathrm{mol}$ for the effect of torsional anharmonicity on the free energy barrier of the $1,8 \mathrm{H}$-shift of $\mathrm{C}_{6} \mathrm{H}_{9} \mathrm{O}_{6}$ (reaction 3a in Scheme 2). Closer inspection of the output revealed that the $\mathrm{C}_{6} \mathrm{H}_{9} \mathrm{O}_{6}$ transition state (with 2 torsions) also had very low $(<0.01 \mathrm{kcal} / \mathrm{mol})$ effective torsional barriers for many conformers. 

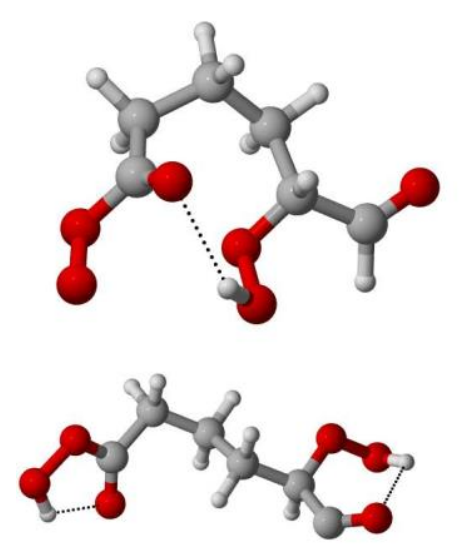
white=hydrogen .

524 cartesian co-ordinates in Table S5.
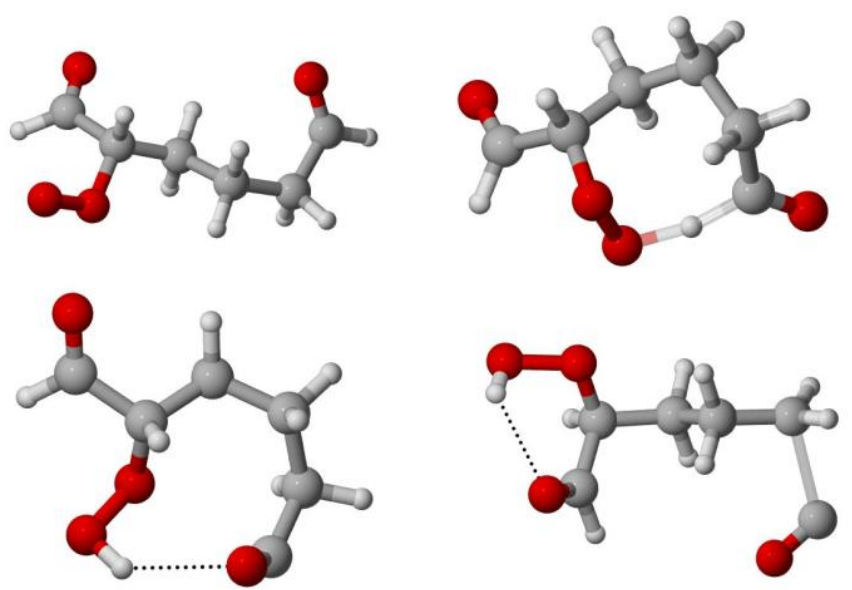

Figure S5 Lowest-energy structures for $\mathrm{C}_{6} \mathrm{H}_{9} \mathrm{O}_{4}$. Top left: reactant. Top right: 1,7 H-shift transition state. Bottom left: product. Bottom right: CO loss transition state. Color coding: gray=carbon, red=oxygen,

\section{S2.4. Molecular structures and thermodynamic parameters of the studied system}

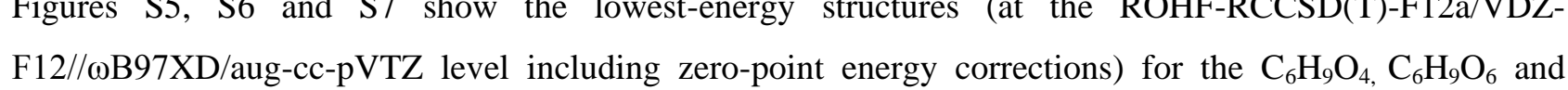
$\mathrm{C}_{6} \mathrm{H}_{9} \mathrm{O}_{8}$ systems, respectively. The corresponding thermodynamic parameters are given in Table $\mathrm{S} 4$, and the
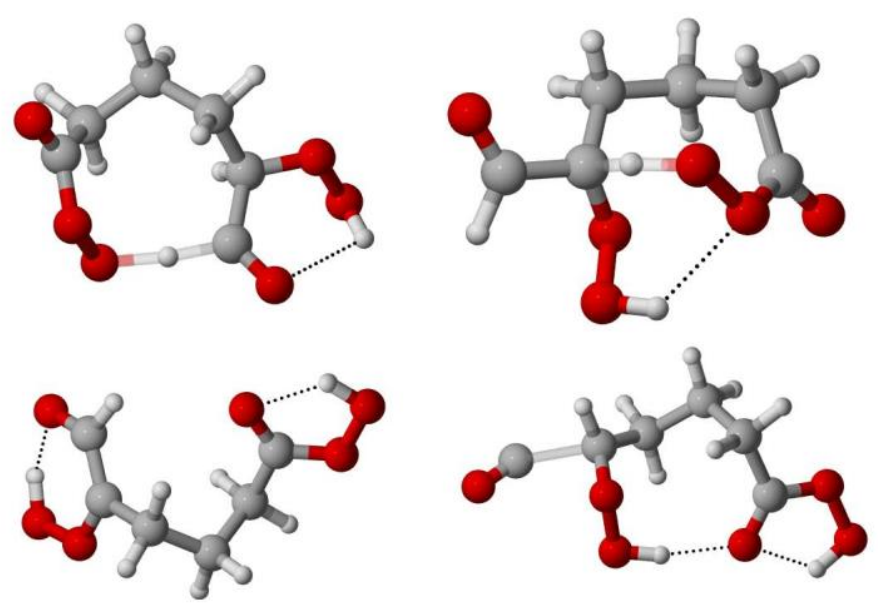
Figure S6 Lowest-energy structures for $\mathrm{C}_{6} \mathrm{H}_{9} \mathrm{O}_{6}$. Top left: reactant. Top middle: 1,8 H-shift transition state.

527 Top right: 1,7 H-shift transition state. Bottom left: 1,8 H-shift product. Bottom middle: 1,7 H-shift product. 528 Bottom right: CO loss transition state. Color coding as in Figure S5.

529
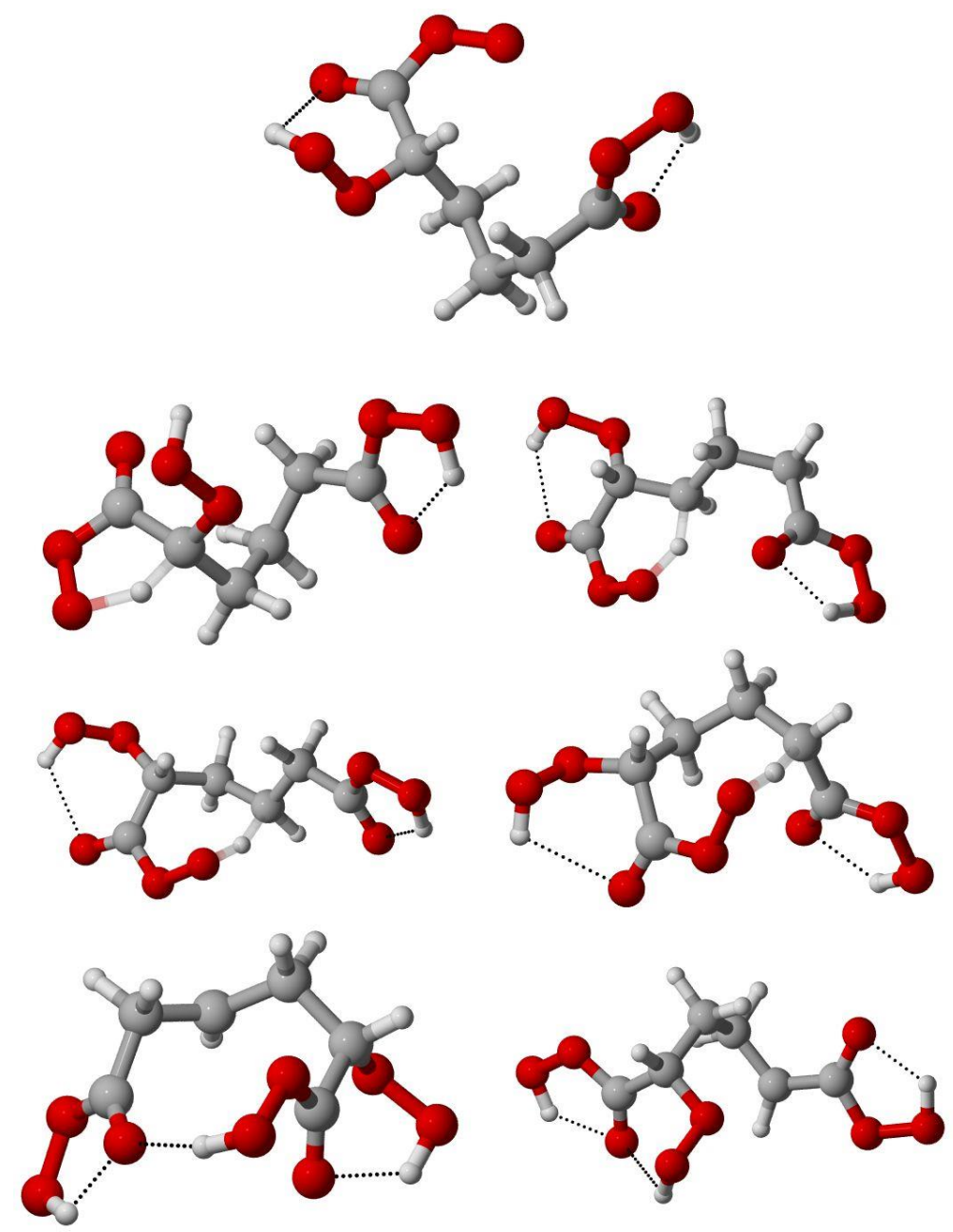

Figure S7 Lowest-energy structures for $\mathrm{C}_{6} \mathrm{H}_{9} \mathrm{O}_{8}$. Top row: reactant. Second row left: 1,4 H-shift transition state. Second row right: 1,5 H-shift transition state. Third row left: 1,6 H-shift transition state. Third row right: 1,7 H-shift transition state. Fourth row left: 1,6 H-shift product. Fourth row right: 1,7 H-shift product. Color coding as in Figure S5. 
Table S4 Energies, zero-point vibrational energies, thermal enthalpy and thermal free energy contributions 544 of the structures shown in Figures S5-S7, and wavenumbers of the imaginary vibrational modes of the 545 transition states.

\begin{tabular}{|c|c|c|c|c|c|c|}
\hline name & $\mathbf{E}_{\text {elec, }}, \mathbf{D F T}^{a, b}$ & $\mathrm{E}_{\text {elec }}, \mathbf{F 1 2}{ }^{a, c}$ & $\begin{array}{l}\text { ZPE, } \\
\text { DFT }^{d}\end{array}$ & $\mathbf{H}_{\text {therm }}{ }^{e}$ & $\mathbf{G}_{\text {therm }}{ }^{f}$ & $\begin{array}{l}\text { Imag. } \\
\text { mode }^{g}\end{array}$ \\
\hline $\mathrm{O}_{2}$ & -150.33429845 & -150.17736641 & 0.003881 & 0.007188 & -0.016069 & - \\
\hline $\mathrm{C}_{6} \mathrm{H}_{9} \mathrm{O}_{4}$ reactant & -534.824880717 & -534.15339617 & 0.147996 & 0.160132 & 0.108268 & - \\
\hline $\mathrm{C}_{6} \mathrm{H}_{9} \mathrm{O}_{4} 1,7 \mathrm{TS}^{h}$ & -534.798589759 & -534.12466692 & 0.144093 & 0.154920 & 0.107580 & $1647.5 \mathrm{i}$ \\
\hline $\begin{array}{l}\mathrm{C}_{6} \mathrm{H}_{9} \mathrm{O}_{4} 1,7 \\
\text { product }^{i}\end{array}$ & -534.818448473 & -534.15265521 & 0.148700 & 0.160676 & 0.110943 & - \\
\hline $\begin{array}{l}\mathrm{C}_{6} \mathrm{H}_{9} \mathrm{O}_{4} \mathrm{CO} \text { loss } \\
\text { TS }\end{array}$ & -534.788765728 & -534.12543581 & 0.144180 & 0.156836 & 0.104288 & $324.7 \mathrm{i}$ \\
\hline $\mathrm{C}_{6} \mathrm{H}_{9} \mathrm{O}_{6}$ reactant & -685.210047983 & -684.39158629 & 0.157809 & 0.171450 & 0.117191 & - \\
\hline $\mathrm{C}_{6} \mathrm{H}_{9} \mathrm{O}_{6} 1,8 \mathrm{TS}$ & -685.184014815 & -684.35868956 & 0.153573 & 0.166247 & 0.114695 & $1522.6 \mathrm{i}$ \\
\hline $\mathrm{C}_{6} \mathrm{H}_{9} \mathrm{O}_{6} 1,7 \mathrm{TS}$ & -685.183123412 & -684.36021210 & 0.153053 & 0.165806 & 0.114568 & $1552.1 \mathrm{i}$ \\
\hline $\mathrm{C}_{6} \mathrm{H}_{9} \mathrm{O}_{6} 1,7$ product & -685.235734867 & -684.41402811 & 0.159310 & 0.172617 & 0.117435 & - \\
\hline $\begin{array}{l}\mathrm{C}_{6} \mathrm{H}_{9} \mathrm{O}_{6} 1,8 \\
\text { product }\end{array}$ & -685.216831503 & -684.40194656 & 0.158345 & 0.172347 & 0.115741 & - \\
\hline $\begin{array}{l}\mathrm{C}_{6} \mathrm{H}_{9} \mathrm{O}_{6} \mathrm{CO} \text { loss } \\
\mathrm{TS}\end{array}$ & -685.199920390 & -684.38435707 & 0.155923 & 0.169908 & 0.114266 & $304.0 \mathrm{i}$ \\
\hline $\mathrm{C}_{6} \mathrm{H}_{9} \mathrm{O}_{8}$ reactant & -835.603426981 & -834.63563540 & 0.167668 & 0.183337 & 0.122589 & - \\
\hline $\mathrm{C}_{6} \mathrm{H}_{9} \mathrm{O}_{8} 1,4 \mathrm{TS}$ & -835.566677026 & -834.59460527 & 0.162282 & 0.177683 & 0.118478 & $1303.2 \mathrm{i}$ \\
\hline $\mathrm{C}_{6} \mathrm{H}_{9} \mathrm{O}_{8} 1,5 \mathrm{TS}$ & -835.563800893 & -834.59600828 & 0.161437 & 0.176412 & 0.117553 & $1827.8 \mathrm{i}$ \\
\hline $\mathrm{C}_{6} \mathrm{H}_{9} \mathrm{O}_{8} 1,6 \mathrm{TS}$ & -835.566270440 & -834.59777991 & 0.161327 & 0.176304 & 0.117723 & $1812.8 \mathrm{i}$ \\
\hline $\mathrm{C}_{6} \mathrm{H}_{9} \mathrm{O}_{8} 1,7 \mathrm{TS}$ & -835.567518408 & -834.59802378 & 0.161699 & 0.176439 & 0.119177 & $1938.3 \mathrm{i}$ \\
\hline $\begin{array}{l}\mathrm{C}_{6} \mathrm{H}_{9} \mathrm{O}_{8} 1,6 \\
\text { product }\end{array}$ & -835.596984075 & -834.63227092 & 0.166466 & 0.182142 & 0.122948 & - \\
\hline $\begin{array}{l}\mathrm{C}_{6} \mathrm{H}_{9} \mathrm{O}_{8} 1,7 \\
\text { product }\end{array}$ & -835.605611663 & -834.63944183 & 0.166804 & 0.182701 & 0.121594 & - \\
\hline
\end{tabular}

${ }^{a}$ Energies (with ${ }^{b}$ DFT referring to $\omega \mathrm{B} 97 \mathrm{XD} /$ aug-cc-pVTZ, and ${ }^{c} \mathrm{~F} 12$ referring to ROHF-RCCSD(T)F12a/VDZ-F12), ${ }^{d}$ zero-point vibrational energies, ${ }^{e}$ thermal enthalpy, and, ${ }^{f}$ thermal free energy contributions 548 of the structures shown in Figures S5-S7, given in Hartree, at $298.15 \mathrm{~K}$ and $1 \mathrm{~atm}$ reference pressure. $549{ }^{g}$ Wavenumbers given in $\mathrm{cm}^{-1} .{ }^{h}$ "1,X TS", and, ${ }^{i}$ " $1, \mathrm{X}$ product" refer to transition states and products of $1, \mathrm{X}$ 550 hydrogen shifts, respectively. 
551 Table S5 Cartesian co-ordinates (in Ångström) of the structures shown in Figures S5-S7 and given in Table 552 S4.

553

$554 \quad \mathrm{O}_{2}$ (triplet)

$\begin{array}{lllll}555 & \mathrm{O} & 0.0 & 0.0 & 0.597986\end{array}$

$\begin{array}{lllll}556 & \mathrm{O} & 0.0 & 0.0 & -0.597986\end{array}$

557

558

$559 \quad \mathrm{C}_{6} \mathrm{H}_{9} \mathrm{O}_{4}$ reactant

$\begin{array}{lllll}560 & \mathrm{C} & -2.5739518 & 1.2524534 & -0.3228367\end{array}$

$\begin{array}{lllll}561 & \mathrm{H} & -3.6006238 & 0.9247124 & -0.5697497\end{array}$

$\begin{array}{lllll}562 & \mathrm{C} & -1.6652128 & 0.1555354 & 0.2187893\end{array}$

$\begin{array}{lllll}563 & \mathrm{H} & -1.6606948 & 0.2329174 & 1.3091033\end{array}$

$\begin{array}{lllll}564 & \mathrm{C} & -0.2614618 & 0.2005084 & -0.3444957\end{array}$

$\begin{array}{lllll}565 & \mathrm{H} & 0.1040662 & 1.2156884 & -0.1933407\end{array}$

$\begin{array}{lllll}566 & \mathrm{H} & -0.3076148 & 0.0310974 & -1.4234897\end{array}$

$\begin{array}{lllll}567 & \mathrm{C} & 0.6764472 & -0.8084966 & 0.3115523\end{array}$

$\begin{array}{lllll}568 & \mathrm{H} & 0.2965712 & -1.8184886 & 0.1574583\end{array}$

$\begin{array}{lllll}569 & \mathrm{H} & 0.6971102 & -0.6322566 & 1.3886893\end{array}$

$\begin{array}{lllll}570 & \mathrm{C} & 2.0947262 & -0.7237726 & -0.2310237\end{array}$

$\begin{array}{lllll}571 & \mathrm{H} & 2.1121462 & -0.7492086 & -1.3257187\end{array}$

$\begin{array}{lllll}572 & \mathrm{C} & 2.8675442 & 0.4906404 & 0.2082923\end{array}$

$\begin{array}{lllll}573 & \mathrm{H} & 3.8753802 & 0.5895794 & -0.2414767\end{array}$

$\begin{array}{lllll}574 & \mathrm{O} & 2.4728512 & 1.3066254 & 0.9957223\end{array}$

$\begin{array}{lllll}575 & \mathrm{O} & -2.2141578 & 2.3846354 & -0.4574207\end{array}$

$\begin{array}{lllll}576 & \mathrm{H} & 2.6886052 & -1.5893366 & 0.0809223\end{array}$

$\begin{array}{lllll}577 & \mathrm{O} & -2.2489098 & -1.1263556 & -0.1103237\end{array}$

$\begin{array}{lllll}578 & \mathrm{O} & -3.3528198 & -1.3364786 & 0.5493473\end{array}$

579

$580 \quad \mathrm{C}_{6} \mathrm{H}_{9} \mathrm{O}_{4} 1,7$ H-shift TS

$\begin{array}{lllll}581 & \mathrm{C} & -2.3773989 & -0.7902039 & -1.0177839\end{array}$

$\begin{array}{lllll}582 & \mathrm{H} & -2.6907109 & -1.8130539 & -0.7390539\end{array}$

$\begin{array}{lllll}583 & \mathrm{C} & -1.3961369 & -0.1451449 & -0.0471519\end{array}$

$\begin{array}{lllll}584 & \mathrm{H} & -1.9676989 & 0.5522031 & 0.5746321\end{array}$

$\begin{array}{lllll}585 & \mathrm{C} & -0.2873569 & 0.5993891 & -0.7800459\end{array}$

$\begin{array}{lllll}586 & \mathrm{H} & -0.7824159 & 1.3044401 & -1.4474039\end{array}$

$\begin{array}{lllll}587 & \mathrm{H} & 0.2406201 & -0.1028799 & -1.4270559\end{array}$

$\begin{array}{lllll}588 & \mathrm{C} & 0.7003831 & 1.3600241 & 0.1047081\end{array}$

$\begin{array}{lllll}589 & \mathrm{H} & 0.1726571 & 2.1296741 & 0.6705001\end{array}$ 


\begin{tabular}{|c|c|c|c|c|}
\hline 590 & $\mathrm{H}$ & 1.3987881 & 1.8791831 & -0.5523109 \\
\hline 591 & C & 1.5151351 & 0.5191751 & 1.1054181 \\
\hline 2 & $\mathrm{H}$ & 0.8912851 & 0.2430691 & 1.9552321 \\
\hline 593 & $\mathrm{C}$ & 2.0033581 & -0.7707879 & 0.4904741 \\
\hline 594 & $\mathrm{H}$ & 1.0118101 & -1.5571679 & 0.3096961 \\
\hline 595 & $\mathrm{O}$ & 3.1044801 & -1.0784389 & 0.1935241 \\
\hline 596 & $\mathrm{O}$ & -2.7993019 & -0.2350519 & -1.9916789 \\
\hline 597 & $\mathrm{H}$ & 2.3799451 & 1.0767491 & 1.4631011 \\
\hline 598 & $\mathrm{O}$ & -0.9455549 & -1.1141029 & 0.8899301 \\
\hline 599 & $\mathrm{O}$ & -0.1718869 & -2.0570739 & 0.2452691 \\
\hline \multicolumn{5}{|l|}{600} \\
\hline 601 & \multicolumn{4}{|c|}{$\mathrm{C}_{6} \mathrm{H}_{9} \mathrm{O}_{4} 1,7 \mathrm{H}$-shift product } \\
\hline 602 & $\mathrm{C}$ & -2.5784244 & 0.2565130 & 0.1240697 \\
\hline 603 & $\mathrm{H}$ & -3.1698764 & -0.4060090 & -0.5345123 \\
\hline 604 & $\mathrm{C}$ & -1.0899994 & -0.0541120 & 0.1742527 \\
\hline 605 & $\mathrm{H}$ & -0.8518874 & -0.3965120 & 1.1870457 \\
\hline 606 & $\mathrm{C}$ & -0.2390604 & 1.1617490 & -0.1670713 \\
\hline 607 & $\mathrm{H}$ & -0.6916984 & 2.0119660 & 0.3433227 \\
\hline 608 & $\mathrm{H}$ & -0.3194754 & 1.3550800 & -1.2400773 \\
\hline 609 & $\mathrm{C}$ & 1.2282116 & 1.0595690 & 0.2436927 \\
\hline 610 & $\mathrm{H}$ & 1.29 & 0.88 & 1.3187707 \\
\hline 611 & $\mathrm{H}$ & 1.6947416 & 2.0274080 & 0.0545367 \\
\hline 612 & $\mathrm{C}$ & 2.0509366 & 0.0004770 & -0.4973253 \\
\hline 613 & $\mathrm{H}$ & 3.1209376 & 0.2111940 & -0.4150883 \\
\hline 614 & $\mathrm{C}$ & 1.9171126 & -1.4140380 & 0.0033577 \\
\hline 615 & $\mathrm{O}$ & 1.4509686 & -1.8199680 & 1.0090997 \\
\hline 616 & $\mathrm{O}$ & -3.0797654 & 1.1526360 & 0.7428147 \\
\hline 617 & $\mathrm{H}$ & 1.8307156 & -0.0137070 & -1.5650393 \\
\hline 618 & $\mathrm{O}$ & -0.7714094 & -1.0735800 & -0.7573373 \\
\hline 619 & $\mathrm{O}$ & -1.2813454 & -2.3012370 & -0.2570243 \\
\hline 620 & $\mathrm{H}$ & -0.5188164 & -2.6415880 & 0.2325117 \\
\hline \multicolumn{5}{|l|}{621} \\
\hline 622 & \multicolumn{4}{|c|}{$\mathrm{C}_{6} \mathrm{H}_{9} \mathrm{O}_{4} \mathrm{CO}$ loss TS } \\
\hline 623 & $\mathrm{C}$ & 3.3979236 & -0.4450339 & 0.0378843 \\
\hline 624 & $\mathrm{C}$ & 2.0723866 & 1.2382751 & 0.6191043 \\
\hline 625 & $\mathrm{C}$ & 0.6970506 & 0.6697771 & 0.6567573 \\
\hline 626 & $\mathrm{C}$ & 0.1165606 & 0.4200131 & -0.7337137 \\
\hline 627 & $\mathrm{C}$ & -1.2695084 & -0.2174029 & -0.7162177 \\
\hline & $\mathrm{O}$ & -2.1355014 & 0.6643301 & -0.0 \\
\hline
\end{tabular}




$\begin{array}{lllll}629 & \mathrm{O} & -3.4639884 & 0.1775541 & -0.1835207 \\ 630 & \mathrm{O} & 2.8714046 & -1.4548809 & 0.0637853 \\ 631 & \mathrm{C} & -1.2276194 & -1.5851669 & -0.0649657 \\ 632 & \mathrm{O} & -1.8987054 & -1.9056589 & 0.8780203 \\ 633 & \mathrm{H} & 2.5715236 & 1.4310421 & 1.5597833 \\ 634 & \mathrm{H} & 2.3356446 & 1.9153041 & -0.1840567 \\ 635 & \mathrm{H} & 0.0397076 & 1.3551121 & 1.2029723 \\ 636 & \mathrm{H} & 0.6973436 & -0.2556359 & 1.2411583 \\ 637 & \mathrm{H} & 0.0502396 & 1.3588601 & -1.2845037 \\ 638 & \mathrm{H} & -0.5208974 & -2.2988409 & -0.5325137 \\ 639 & \mathrm{H} & -1.6109984 & -0.3690839 & -1.7490187 \\ 640 & \mathrm{H} & 0.7775966 & -0.2367469 & -1.3026027 \\ 641 & \mathrm{H} & -3.5001634 & -0.4618169 & 0.5417023\end{array}$

642

$643 \quad \mathrm{C}_{6} \mathrm{H}_{9} \mathrm{O}_{6}$ reactant

$\begin{array}{lllll}644 & \mathrm{C} & 1.9470966 & 0.0508505 & -0.1259375\end{array}$

$\begin{array}{lllll}645 & \mathrm{C} & 1.3627836 & 1.2933705 & 0.4671175\end{array}$

$\begin{array}{lllll}646 & \mathrm{H} & 2.1170236 & 2.0738415 & 0.3328765\end{array}$

$\begin{array}{lllll}647 & \mathrm{H} & 1.2531706 & 1.1468665 & 1.5412505\end{array}$

$\begin{array}{lllll}648 & \mathrm{C} & 0.0468236 & 1.7188865 & -0.1816425\end{array}$

$\begin{array}{lllll}649 & \mathrm{H} & 0.1595626 & 1.7066495 & -1.2667835\end{array}$

$\begin{array}{lllll}650 & \mathrm{H} & -0.1388684 & 2.7547175 & 0.1020835\end{array}$

$\begin{array}{lllll}651 & \mathrm{C} & -1.1757174 & 0.8946795 & 0.2200265\end{array}$

$\begin{array}{lllll}652 & \mathrm{H} & -2.0684364 & 1.3595895 & -0.1980795\end{array}$

$\begin{array}{lllll}653 & \mathrm{H} & -0.8493114 & -0.5818065 & -1.3148265\end{array}$

$\begin{array}{lllll}654 & \mathrm{H} & -1.2953324 & 0.8974955 & 1.3066635\end{array}$

$\begin{array}{lllll}655 & \mathrm{O} & 2.7679796 & -0.5819635 & 0.8538225\end{array}$

$\begin{array}{lllll}656 & \mathrm{O} & 3.2635586 & -1.7209535 & 0.4541375\end{array}$

$\begin{array}{lllll}657 & \mathrm{O} & 1.8447866 & -0.3813875 & -1.2241115\end{array}$

$\begin{array}{llllll}658 & \mathrm{C} & -1.1711084 & -0.5479985 & -0.2686385\end{array}$

$\begin{array}{lllll}659 & \mathrm{C} & -2.5495904 & -1.1858305 & -0.1817335\end{array}$

$\begin{array}{lllll}660 & \mathrm{H} & -2.5867984 & -2.1407595 & 0.3737795\end{array}$

$\begin{array}{llllll}661 & \mathrm{O} & -3.5267554 & -0.6939785 & -0.6715915\end{array}$

$\begin{array}{llllll}662 & \mathrm{O} & -0.2481574 & -1.2707975 & 0.5308475\end{array}$

$\begin{array}{lllll}663 & \mathrm{O} & 0.0265556 & -2.5038275 & -0.1178515\end{array}$

$\begin{array}{lllll}664 & \mathrm{H} & 0.8207356 & -2.2876435 & -0.6314095\end{array}$

665

$666 \mathrm{C}_{6} \mathrm{H}_{9} \mathrm{O}_{6} 1,8$ H-shift TS

$\begin{array}{lllll}667 & \mathrm{C} & 0.3029300 & -1.9228668 & 1.5033120\end{array}$ 


\begin{tabular}{|c|c|c|c|c|}
\hline 668 & $\mathrm{C}$ & 0.6197360 & -0.4806288 & 1.8021020 \\
\hline 669 & $\mathrm{H}$ & 1.1602690 & -0.4770898 & 2.7468930 \\
\hline 670 & $\mathrm{H}$ & -0.2839420 & 0.1076102 & 1.9233060 \\
\hline 671 & $\mathrm{C}$ & 1.5310230 & 0.0935392 & 0.7078080 \\
\hline 672 & $\mathrm{H}$ & 2.4623950 & -0.4722628 & 0.7025270 \\
\hline 673 & $\mathrm{H}$ & 1.7805020 & 1.1221112 & 0.9728780 \\
\hline 674 & $\mathrm{C}$ & 0.9482560 & 0.0622702 & -0.7028850 \\
\hline 675 & $\mathrm{H}$ & 0.7399050 & -0.9659388 & -1.0051630 \\
\hline 676 & $\mathrm{H}$ & -0.4870130 & 1.5659532 & -0.0179630 \\
\hline 677 & $\mathrm{H}$ & 1.6932740 & 0.4371382 & -1.4039630 \\
\hline 678 & $\mathrm{O}$ & -0.9607660 & -2.2574218 & 1.0615970 \\
\hline 679 & $\mathrm{O}$ & -1.8839030 & -1.2384688 & 1.0884110 \\
\hline 680 & $\mathrm{O}$ & 1.0908310 & -2.8163638 & 1.5569540 \\
\hline 681 & $\mathrm{C}$ & -0.2964750 & 0.9431582 & -0.8993300 \\
\hline 682 & $\mathrm{C}$ & -1.5461970 & 0.0824082 & -1.0841820 \\
\hline 683 & $\mathrm{H}$ & -1.7719870 & -0.6170858 & -0.0664240 \\
\hline 684 & $\mathrm{O}$ & -2.2552720 & 0.0457672 & -2.0266420 \\
\hline 685 & $\mathrm{O}$ & -0.0584330 & 1.7543452 & -2.0172440 \\
\hline 686 & $\mathrm{O}$ & -1.0961710 & 2.7192752 & -2.0980370 \\
\hline 687 & $\mathrm{H}$ & -1.6889630 & 2.3145512 & -2.7439550 \\
\hline \multicolumn{5}{|l|}{688} \\
\hline 689 & \multicolumn{4}{|c|}{$\mathrm{C}_{6} \mathrm{H}_{9} \mathrm{O}_{6} 1,7 \mathrm{H}$-shift TS } \\
\hline 69 & $\mathrm{C}$ & 8 & -0.80 & 0.1744345 \\
\hline 691 & $\mathrm{C}$ & 1.8865258 & 0.6985615 & 0.1334465 \\
\hline 692 & $\mathrm{H}$ & 2.8698248 & 1.0459595 & -0.1753055 \\
\hline 693 & $\mathrm{H}$ & 1.6625248 & 1.1014465 & 1.1176435 \\
\hline 694 & $\mathrm{C}$ & 0.8539018 & 1.1758355 & -0.9062905 \\
\hline 695 & $\mathrm{H}$ & 0.9588938 & 0.5770205 & -1.8108295 \\
\hline 696 & $\mathrm{H}$ & 1.1187538 & 2.1963495 & -1.1810015 \\
\hline 697 & $\mathrm{C}$ & -0.6078412 & 1.2016525 & -0.4564385 \\
\hline 698 & $\mathrm{H}$ & -1.2214972 & 1.5695875 & -1.2823025 \\
\hline 699 & $\mathrm{H}$ & -0.5608162 & -0.3998955 & 1.0632655 \\
\hline 700 & $\mathrm{H}$ & -0.7473792 & 1.9034615 & 0.3662315 \\
\hline 701 & $\mathrm{O}$ & 1.2117588 & -1.5151605 & 1.0594145 \\
\hline 702 & $\mathrm{O}$ & 0.4157748 & -0.7412415 & 1.8666085 \\
\hline 703 & $\mathrm{O}$ & 2.7218818 & -1.4591615 & -0.5186535 \\
\hline ב & $\mathrm{C}$ & -1.1716612 & -0.1206165 & 0.0121805 \\
\hline 705 & $\mathrm{C}$ & -2.6076942 & -0.0971775 & 0.4761365 \\
\hline & $\mathrm{H}$ & -3.1915142 & -1.0034035 & 0.2513845 \\
\hline
\end{tabular}




$\begin{array}{lllll}707 & \mathrm{O} & -3.0704232 & 0.8415495 & 1.0620305 \\ 708 & \mathrm{O} & -0.8542712 & -1.1136315 & -0.8922255 \\ 709 & \mathrm{O} & -1.2554412 & -2.3752795 & -0.3746405 \\ 710 & \mathrm{H} & -0.4244882 & -2.6844455 & 0.0149105\end{array}$

711

$712 \quad \mathrm{C}_{6} \mathrm{H}_{9} \mathrm{O}_{6} 1,8 \mathrm{H}$-shift product

$\begin{array}{lllll}713 & \mathrm{C} & 2.5253058 & 0.0093651 & 0.0902010\end{array}$

$\begin{array}{lllll}714 & \mathrm{C} & 1.6017688 & 1.0204331 & -0.5292320\end{array}$

$\begin{array}{lllll}715 & \mathrm{H} & 1.5793088 & 0.8685911 & -1.6083130\end{array}$

$\begin{array}{lllll}716 & \mathrm{H} & 2.0595508 & 1.9973591 & -0.3592900\end{array}$

$\begin{array}{lllll}717 & \mathrm{C} & 0.2036718 & 0.9852941 & 0.0758440\end{array}$

$\begin{array}{lllll}718 & \mathrm{H} & -0.3614522 & 1.8317881 & -0.3107990\end{array}$

$\begin{array}{lllll}719 & \mathrm{H} & 0.2777198 & 1.1116121 & 1.1568320\end{array}$

$\begin{array}{lllll}720 & \mathrm{C} & -0.5346422 & -0.3124099 & -0.2349490\end{array}$

$\begin{array}{lllll}721 & \mathrm{H} & 0.0100728 & -1.1663899 & 0.1694000\end{array}$

$\begin{array}{lllll}722 & \mathrm{H} & -1.8968802 & -0.1655229 & 1.4438290\end{array}$

$\begin{array}{lllll}723 & \mathrm{H} & -0.6112472 & -0.4570669 & -1.3153720\end{array}$

$\begin{array}{lllll}724 & \mathrm{O} & 3.4710718 & -0.3788079 & -0.7765960\end{array}$

$\begin{array}{lllll}725 & \mathrm{O} & 2.4820378 & -0.4161049 & 1.2171180\end{array}$

$\begin{array}{lllll}726 & \mathrm{C} & -1.9321222 & -0.3416159 & 0.3638060\end{array}$

$\begin{array}{lllll}727 & \mathrm{C} & -2.5692962 & -1.7290939 & 0.1902730\end{array}$

$\begin{array}{lllll}728 & \mathrm{O} & -3.6182852 & -1.9697209 & -0.2797370\end{array}$

$\begin{array}{lllll}729 & \mathrm{O} & -2.6863542 & 0.6647421 & -0.2671430\end{array}$

$\begin{array}{lllll}730 & \mathrm{O} & -3.8929312 & 0.8478861 & 0.4544730\end{array}$

$\begin{array}{lllll}731 & \mathrm{H} & -4.4930542 & 0.2513031 & -0.0114950\end{array}$

$\begin{array}{lllll}732 & \mathrm{O} & 4.3799268 & -1.2852129 & -0.1846640\end{array}$

$\begin{array}{lllll}733 & \mathrm{H} & 4.0058308 & -1.3664279 & 0.7158150\end{array}$

734

$735 \quad \mathrm{C}_{6} \mathrm{H}_{9} \mathrm{O}_{6} 1,7 \mathrm{H}$-shift product

$\begin{array}{lllll}736 & \mathrm{C} & 2.0191544 & -0.1677872 & 0.2272037 \\ 737 & \mathrm{C} & 1.0182214 & 0.8195978 & 0.7473687 \\ 738 & \mathrm{C} & 0.1757724 & 1.4377188 & -0.3771003 \\ 739 & \mathrm{C} & -0.7279436 & 0.4445138 & -1.1217363 \\ 740 & \mathrm{C} & -1.7183686 & -0.2312052 & -0.2341993 \\ 741 & \mathrm{C} & -1.6677066 & -1.6014842 & 0.0968797 \\ 742 & \mathrm{O} & -2.4919726 & -2.1690082 & 0.8426877 \\ 743 & \mathrm{O} & -2.6344566 & 0.6116118 & 0.2182587 \\ 744 & \mathrm{O} & -3.5903726 & 0.1047258 & 1.1303047 \\ 745 & \mathrm{H} & -3.3667176 & -0.8683382 & 1.1763817\end{array}$




$\begin{array}{lllll}746 & \mathrm{O} & 1.7869464 & -1.2482132 & -0.2597033 \\ 747 & \mathrm{O} & 3.2696614 & 0.2985798 & 0.3384557 \\ 748 & \mathrm{O} & 4.2157464 & -0.6132072 & -0.1801043 \\ 749 & \mathrm{H} & 3.6354614 & -1.3501822 & -0.4590353 \\ 750 & \mathrm{H} & 0.3761814 & 0.2860718 & 1.4497957 \\ 751 & \mathrm{H} & 1.5380394 & 1.6042988 & 1.2922407 \\ 752 & \mathrm{H} & 0.8319124 & 1.9230048 & -1.1004723 \\ 753 & \mathrm{H} & -1.2646026 & 0.9842058 & -1.9040583 \\ 754 & \mathrm{H} & -0.1293486 & -0.3258112 & -1.6044183 \\ 755 & \mathrm{H} & -0.4411646 & 2.2196428 & 0.0644377 \\ 756 & \mathrm{H} & -0.8344436 & -2.1587352 & -0.3431873 \\ 757 & & & & \end{array}$

\section{$758 \quad \mathrm{C}_{6} \mathrm{H}_{9} \mathrm{O}_{6} \mathrm{CO}$ loss TS}

$\begin{array}{lllll}759 & \mathrm{C} & 1.9043726 & -0.3534020 & 0.3125963 \\ 760 & \mathrm{C} & 1.1390106 & 0.8238700 & 0.8292883 \\ 761 & \mathrm{C} & 0.2553026 & 1.4606000 & -0.2574917 \\ 762 & \mathrm{C} & -0.8789574 & 0.5788890 & -0.7961907 \\ 763 & \mathrm{C} & -1.8835334 & 0.1834530 & 0.2398823 \\ 764 & \mathrm{O} & 1.5151036 & -1.4992360 & 0.2283033 \\ 765 & \mathrm{O} & 3.1234916 & -0.0086850 & -0.1008337 \\ 766 & \mathrm{O} & 3.8350766 & -1.1014810 & -0.6430097 \\ 767 & \mathrm{H} & 3.1927496 & -1.8292610 & -0.5266617 \\ 768 & \mathrm{H} & 1.8446556 & 1.5642180 & 1.2012323 \\ 769 & \mathrm{H} & 0.5291626 & 0.4710210 & 1.6595343 \\ 770 & \mathrm{H} & 0.8869726 & 1.7774950 & -1.0893217 \\ 771 & \mathrm{H} & -0.1715844 & 2.3686690 & 0.1711553 \\ 772 & \mathrm{H} & -1.4107644 & 1.1374380 & -1.5668177 \\ 773 & \mathrm{H} & -0.4874574 & -0.3143470 & -1.2827417 \\ 774 & \mathrm{O} & -1.6143484 & -0.8255920 & 1.1114723 \\ 775 & \mathrm{O} & -1.2339624 & -2.0066450 & 0.4075313 \\ 776 & \mathrm{H} & -0.2616794 & -1.9538540 & 0.4427233 \\ 777 & \mathrm{H} & -2.3541944 & 0.9800090 & 0.8102983 \\ 778 & \mathrm{C} & -3.5980034 & -0.4038130 & -0.8700027 \\ 779 & \mathrm{O} & -4.3314124 & -1.0493460 & -0.2809457 \\ 780 & & & & \end{array}$

780

$781 \quad \mathrm{C}_{6} \mathrm{H}_{9} \mathrm{O}_{8}$ reactant

$\begin{array}{lllll}782 & \mathrm{C} & 2.2594118 & -0.0145370 & 0.0666580\end{array}$

$\begin{array}{lllll}783 & \mathrm{C} & 1.4461558 & 1.2475740 & 0.1009180\end{array}$

$\begin{array}{lllll}784 & \mathrm{H} & 2.1540308 & 2.0750150 & 0.0248150\end{array}$ 


\begin{tabular}{|c|c|c|c|c|}
\hline 785 & $\mathrm{H}$ & 0.9593508 & 1.3413330 & 1.0704130 \\
\hline 786 & $\mathrm{C}$ & 0.4471818 & 1.3274980 & -1.0516570 \\
\hline 787 & $\mathrm{H}$ & 0.9922588 & 1.3546450 & -1.9944930 \\
\hline 788 & $\mathrm{H}$ & -0.0952322 & 2.2668940 & -0.9618140 \\
\hline 789 & $\mathrm{C}$ & -0.5384212 & 0.1611090 & -1.1170730 \\
\hline 790 & $\mathrm{H}$ & -0.0077502 & -0.7595370 & -1.3566300 \\
\hline 791 & $\mathrm{H}$ & -0.6393722 & -0.2855240 & 1.0128600 \\
\hline 792 & $\mathrm{H}$ & -1.2549472 & 0.3417480 & -1.9192550 \\
\hline 793 & $\mathrm{O}$ & 2.4464358 & -0.5068940 & 1.2990920 \\
\hline 794 & $\mathrm{O}$ & 2.7135338 & -0.5538700 & -0.9107980 \\
\hline 795 & $\mathrm{C}$ & -1.3114452 & -0.0593060 & 0.1835730 \\
\hline 796 & $\mathrm{O}$ & -2.0154562 & 1.1280980 & 0.4381170 \\
\hline 797 & $\mathrm{O}$ & -2.6080892 & 1.0286570 & 1.7251460 \\
\hline 798 & $\mathrm{H}$ & -3.5142062 & 0.7844000 & 1.4983830 \\
\hline 799 & $\mathrm{O}$ & 3.2414768 & -1.6745610 & 1.2785800 \\
\hline 800 & $\mathrm{H}$ & 3.3919778 & -1.7833810 & 0.3178210 \\
\hline 801 & $\mathrm{C}$ & -2.3058812 & -1.2009870 & 0.0400200 \\
\hline 802 & $\mathrm{O}$ & -3.4770402 & -1.1100180 & -0.0957450 \\
\hline 803 & $\mathrm{O}$ & -1.7873752 & -2.5206350 & 0.0717060 \\
\hline 804 & $\mathrm{O}$ & -0.4965982 & -2.5877200 & 0.2793640 \\
\hline 805 & & & & \\
\hline 806 & \multicolumn{4}{|c|}{$\mathrm{C}_{6} \mathrm{H}_{9} \mathrm{O}_{8} 1,4 \mathrm{H}$-shift TS } \\
\hline 307 & $\mathrm{C}$ & 2.2229443 & 0.0621679 & 0.1368969 \\
\hline 808 & $\mathrm{C}$ & 1.1788303 & 0.8331299 & 0.8901669 \\
\hline 809 & $\mathrm{H}$ & 1.7139323 & 1.5291999 & 1.5398479 \\
\hline 810 & $\mathrm{H}$ & 0.6345003 & 0.1580649 & 1.5479599 \\
\hline 811 & $\mathrm{C}$ & 0.2357393 & 1.6159089 & -0.0174481 \\
\hline 812 & $\mathrm{H}$ & 0.8032413 & 2.3639269 & -0.5701081 \\
\hline 813 & $\mathrm{H}$ & -0.4644907 & 2.1531809 & 0.6220209 \\
\hline 814 & $\mathrm{C}$ & -0.5405217 & 0.7882089 & -1.0509631 \\
\hline 815 & $\mathrm{H}$ & 0.1402683 & 0.3967549 & -1.8070861 \\
\hline 816 & $\mathrm{H}$ & -2.2752417 & -0.6208561 & -1.2524661 \\
\hline 817 & $\mathrm{H}$ & -1.2491527 & 1.4398419 & -1.5613801 \\
\hline 818 & $\mathrm{O}$ & 2.6793963 & -0.9671381 & 0.8636739 \\
\hline 819 & $\mathrm{O}$ & 2.6489053 & 0.3015359 & -0.9653931 \\
\hline 820 & $\mathrm{C}$ & -1.3181117 & -0.3869271 & -0.4993741 \\
\hline 82 & $\mathrm{O}$ & -0.4789247 & -1.4423081 & -0.3009891 \\
\hline 82 & $\mathrm{O}$ & -1.2203477 & -2.5316441 & 0.2306229 \\
\hline 32 & $\mathrm{H}$ & -0.8409527 & -2.6051231 & 1.1153349 \\
\hline
\end{tabular}




$\begin{array}{lllll}824 & \mathrm{O} & 3.6999203 & -1.6718151 & 0.1855989 \\ 825 & \mathrm{H} & 3.7417233 & -1.1777481 & -0.6578631 \\ 826 & \mathrm{C} & -2.2576677 & -0.0831431 & 0.6724549 \\ 827 & \mathrm{O} & -1.9659747 & 0.0271949 & 1.8207259 \\ 828 & \mathrm{O} & -3.5082567 & 0.0789939 & 0.2066979 \\ 829 & \mathrm{O} & -3.5797587 & -0.2614061 & -1.1489311\end{array}$

830

$831 \mathrm{C}_{6} \mathrm{H}_{9} \mathrm{O}_{8} 1,5 \mathrm{H}$-shift TS

$\begin{array}{lllll}832 & \mathrm{C} & 2.6181002 & -0.0029391 & -0.0911303\end{array}$

$\begin{array}{lllll}833 & \mathrm{C} & 1.7954332 & 1.1613369 & -0.5702213\end{array}$

$\begin{array}{lllll}834 & \mathrm{H} & 1.7151682 & 1.1216099 & -1.6564103\end{array}$

$\begin{array}{lllll}835 & \mathrm{H} & 2.3615902 & 2.0638029 & -0.3323753\end{array}$

$\begin{array}{lllll}836 & \mathrm{C} & 0.4274272 & 1.2130119 & 0.0957777\end{array}$

$\begin{array}{lllll}837 & \mathrm{H} & -0.0645938 & 2.1495729 & -0.1843103\end{array}$

$\begin{array}{lllll}838 & \mathrm{H} & 0.5410352 & 1.2305089 & 1.1807557\end{array}$

$\begin{array}{lllll}839 & \mathrm{C} & -0.4819778 & 0.0855729 & -0.3002423\end{array}$

$\begin{array}{lllll}840 & \mathrm{H} & -0.0965998 & -1.0149641 & 0.2788097\end{array}$

$\begin{array}{lllll}841 & \mathrm{H} & -1.8082688 & 0.3652889 & 1.3623787\end{array}$

$\begin{array}{lllll}842 & \text { H } & -0.4799628 & -0.1663471 & -1.3611393\end{array}$

$\begin{array}{lllll}843 & \mathrm{O} & 3.5666512 & -0.3234471 & -0.9785613\end{array}$

$\begin{array}{lllll}844 & \mathrm{O} & 2.4906382 & -0.5899721 & 0.9529467\end{array}$

$\begin{array}{lllll}845 & \mathrm{C} & -1.8637828 & 0.0902669 & 0.3043507\end{array}$

$\begin{array}{llllll}846 & \mathrm{O} & -2.6476278 & 1.0184469 & -0.4009733\end{array}$

$\begin{array}{llllll}847 & \mathrm{O} & -3.8538068 & 1.2281309 & 0.3205777\end{array}$

$\begin{array}{lllll}848 & \mathrm{H} & -4.3798578 & 0.4684889 & 0.0299207\end{array}$

$849 \quad \mathrm{O} \quad 4.3802592 \quad-1.3813391 \quad-0.5134983$

$\begin{array}{lllll}850 & \mathrm{H} & 3.9560972 & -1.5869331 & 0.3437837\end{array}$

$\begin{array}{lllll}851 & \mathrm{C} & -2.4876618 & -1.3048131 & 0.2029737\end{array}$

$852 \quad \mathrm{O} \quad-3.6049458 \quad-1.5293341 \quad-0.1506433$

$\begin{array}{lllll}853 & \mathrm{O} & -1.6562348 & -2.3433871 & 0.4671037\end{array}$

$854 \quad \mathrm{O} \quad-0.4270798 \quad-1.9525621 \quad 1.0001257$

855

856

$857 \quad \mathrm{C}_{6} \mathrm{H}_{9} \mathrm{O}_{8} 1,6 \mathrm{H}$-shift TS

$\begin{array}{lllll}858 & \mathrm{C} & 2.7943931 & 0.0018830 & -0.0136164\end{array}$

$\begin{array}{lllll}859 & \mathrm{C} & 1.4653341 & 0.7000340 & -0.1171904\end{array}$

$\begin{array}{lllll}860 & \mathrm{H} & 1.6488631 & 1.6504470 & -0.6314544\end{array}$

$\begin{array}{lllll}861 & \mathrm{H} & 1.1078271 & 0.9557010 & 0.8805046\end{array}$

$862 \quad \mathrm{C} \quad 0.4538141-0.1014540 \quad-0.8928544$ 


\begin{tabular}{|c|c|c|c|c|}
\hline 63 & $\mathrm{H}$ & 0.2279941 & -1.1330140 & -0.1304144 \\
\hline 4 & I & 0.8548851 & -0.5558350 & -1.7942994 \\
\hline 65 & $\mathrm{C}$ & -0.9150359 & 0.5200870 & -1.0342924 \\
\hline 866 & $\mathrm{H}$ & -1.4302169 & 0.1195800 & -1.9058964 \\
\hline 67 & $\mathrm{H}$ & -1.2565399 & 0.5083180 & 1.1278156 \\
\hline 868 & 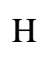 & -0.8239949 & 1.5993550 & -1.1822484 \\
\hline 60 & $\mathrm{O}$ & 3.4723761 & 0.4255940 & 1.0579736 \\
\hline 70 & $\mathrm{O}$ & 3.2375291 & -0.8129830 & -0.7798064 \\
\hline 71 & 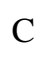 & -1.8098089 & 0.3280830 & 0.2039726 \\
\hline 872 & $\mathrm{O}$ & -2.8428389 & 1.2647700 & 0.0645986 \\
\hline 873 & $\mathrm{O}$ & -3.6451699 & 1.2214790 & 1.2341606 \\
\hline 874 & $\mathrm{H}$ & -4.2900429 & 0.5422700 & 0.9916706 \\
\hline 875 & o & 4.7491641 & -0.1734010 & 1.1385276 \\
\hline 76 & I & 4.7316291 & -0.7711120 & 0.3647496 \\
\hline 77 & $\mathrm{C}$ & -2.3955289 & -1.0832030 & 0.2203536 \\
\hline 78 & 0 & -3.5456889 & -1.3401040 & 0.0378976 \\
\hline 879 & $\mathrm{O}$ & -1.5241239 & -2.1237290 & 0.3578496 \\
\hline 880 & $\mathrm{O}$ & -0.2648189 & -1.7427650 & 0.8019986 \\
\hline & & & & \\
\hline 882 & \multicolumn{4}{|c|}{$\mathrm{C}_{6} \mathrm{H}_{9} \mathrm{O}_{8} 1,7 \mathrm{H}$-shift TS } \\
\hline 83 & $\mathrm{C}$ & -2.1953498 & -0.1106593 & 0.2309493 \\
\hline 884 & $\mathrm{C}$ & -1.4212908 & 0.6173677 & -0.7988567 \\
\hline 885 & $\mathrm{H}$ & -2.0398918 & 0.9435487 & -1.6308067 \\
\hline 886 & $\mathrm{H}$ & -0.7541168 & -0.3427623 & -1.3804327 \\
\hline 887 & $\mathrm{C}$ & -0.3768318 & 1.6089707 & -0.3537997 \\
\hline 88 & I & -0.8905138 & 2.4177787 & 0.1750533 \\
\hline 880 & 1 & 0.0562102 & 2.0570667 & -1.2492117 \\
\hline 890 & $\mathrm{C}$ & 0.7450292 & 1.1080057 & 0.5583603 \\
\hline 891 & $\mathrm{H}$ & 0.3389242 & 0.6981467 & 1.4800483 \\
\hline 89 & $\mathrm{H}$ & 1.8838312 & 0.2947107 & -1.1262047 \\
\hline 893 & $\mathrm{H}$ & 1.3494502 & 1.9725887 & 0.8325333 \\
\hline 94 & $\mathrm{O}$ & -3.2961738 & -0.6576623 & -0.3073587 \\
\hline 895 & $\mathrm{O}$ & -1.9165308 & -0.2462323 & 1.3974933 \\
\hline 896 & F & 1.7364882 & 0.1110997 & -0.0616347 \\
\hline 897 & 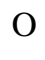 & 2.9388382 & 0.3359097 & 0.6346923 \\
\hline 89 & $\mathrm{O}$ & 3.9423482 & -0.4978373 & 0.0759453 \\
\hline 89 & $\mathrm{H}$ & 3.9157702 & -1.2528923 & 0.6780153 \\
\hline & $\mathrm{O}$ & -4.0283578 & -1.3929723 & 0.6462493 \\
\hline & $\mathrm{H}$ & -3.4737638 & -1.2825303 & 1.4447453 \\
\hline
\end{tabular}




\begin{tabular}{|c|c|c|c|c|}
\hline 02 & $\mathrm{C}$ & 1.3130452 & -1.3406363 & 0.1656473 \\
\hline 3 & $\mathrm{O}$ & 1.7099572 & -2.0339453 & 1.0462393 \\
\hline 904 & $\mathrm{O}$ & 0.3803032 & -1.8956523 & -0.6833277 \\
\hline & $\mathrm{O}$ & 0.0826252 & -1.1114123 & -1.7743397 \\
\hline \multicolumn{5}{|l|}{906} \\
\hline \multicolumn{5}{|l|}{907} \\
\hline & \multicolumn{4}{|c|}{$\mathrm{C}_{6} \mathrm{H}_{9} \mathrm{O}_{8} 1,6 \mathrm{H}$-shift product } \\
\hline & $\mathrm{C}$ & 2.1774067 & 0.0521158 & -0.0875762 \\
\hline & $\mathrm{O}$ & 2.0428057 & 1.2551418 & -0.1078452 \\
\hline 11 & $\mathrm{C}$ & 1.5051287 & -0.9245942 & 0.8449968 \\
\hline 12 & $\mathrm{C}$ & 0.2462917 & -1.4598292 & 0.2417038 \\
\hline & $\mathrm{C}$ & -1.0853983 & -1.2968392 & 0.8832188 \\
\hline & $\mathrm{C}$ & -1.9906533 & -0.2632582 & 0.1869308 \\
\hline & $\mathrm{C}$ & -1.2461583 & 1.0514998 & -0.0506842 \\
\hline & $\mathrm{O}$ & -1.0670673 & 1.5616218 & -1.1154962 \\
\hline 17 & $\mathrm{O}$ & -2.3656693 & -0.8278272 & -1.0402522 \\
\hline 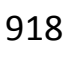 & $\mathrm{O}$ & -3.3424443 & 0.0081038 & -1.6427152 \\
\hline 19 & $\mathrm{H}$ & -2.7799643 & 0.6672488 & -2.0749742 \\
\hline 20 & $\mathrm{O}$ & 2.9598757 & -0.5756022 & -0.9618662 \\
\hline & $\mathrm{O}$ & 3.5439637 & 0.3094698 & -1.8946612 \\
\hline & $\mathrm{H}$ & 3.1700407 & 1.1671968 & -1.6128432 \\
\hline 072 & $\mathrm{O}$ & -0.7884573 & 1.5124948 & 1.1295118 \\
\hline & $\mathrm{O}$ & -0.0740083 & 2.7253978 & 1.0052018 \\
\hline 25 & $\mathrm{H}$ & 0.7595957 & 2.4072728 & 0.6099578 \\
\hline 26 & $\mathrm{H}$ & -2.8753163 & -0.0660822 & 0.7986538 \\
\hline 27 & $\mathrm{H}$ & -1.6356133 & -2.2403642 & 0.8648708 \\
\hline 28 & $\mathrm{H}$ & -0.9785293 & -0.9943592 & 1.9243578 \\
\hline 9 & $\mathrm{H}$ & 0.3096277 & -1.9416502 & -0.7241242 \\
\hline 20 & $\mathrm{H}$ & 2.2127337 & -1.7337582 & 1.0507388 \\
\hline 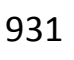 & $\mathrm{H}$ & 1.3018087 & -0.3933992 & 1.7728948 \\
\hline \multicolumn{5}{|l|}{932} \\
\hline & \multicolumn{4}{|c|}{$\mathrm{C}_{6} \mathrm{H}_{9} \mathrm{O}_{8} 1,7 \mathrm{H}$-shift product } \\
\hline & $\mathrm{C}$ & 2.5881395 & 0.0546671 & -0.1178608 \\
\hline & $\mathrm{O}$ & 3.0338975 & 0.0338101 & 1.0141972 \\
\hline & $\mathrm{C}$ & 1.3505195 & 0.6466001 & -0.5422348 \\
\hline 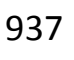 & $\mathrm{C}$ & 0.4594515 & 1.2875541 & 0.4550862 \\
\hline & $\mathrm{C}$ & -0.2928635 & 0.2850191 & 1.3527482 \\
\hline & $\mathrm{C}$ & -1.2114975 & -0.6827999 & 0.6098272 \\
\hline & $\mathrm{C}$ & -2.1301325 & 0.0544861 & -0.3550 \\
\hline
\end{tabular}




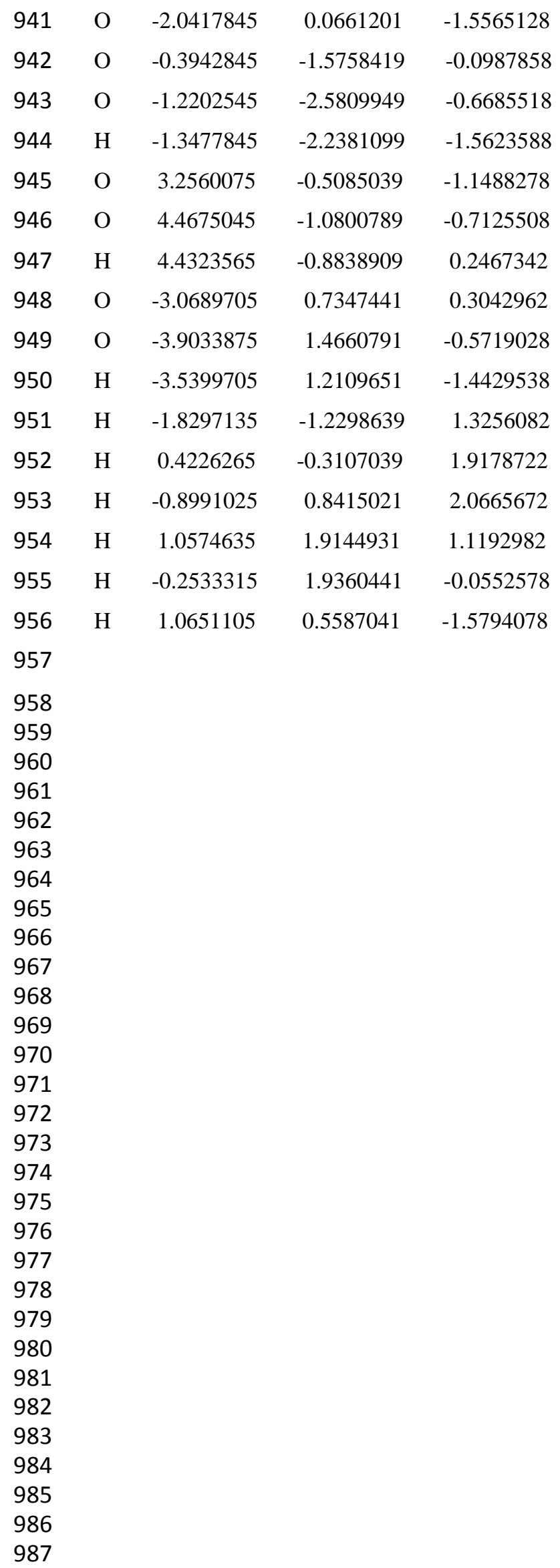


Table S6 Conformers of the reactant for the $\mathrm{C}_{6} \mathrm{H}_{9} \mathrm{O}_{4} 1,7 \mathrm{H}$-shift.

\begin{tabular}{|c|c|c|c|c|}
\hline $\begin{array}{l}\text { Conformer } \\
\text { number }\end{array}$ & $\begin{array}{r}\text { Vibrational partition } \\
\text { function } \\
\end{array}$ & $\begin{array}{r}\text { Rotational partition } \\
\text { function } \\
\end{array}$ & $\begin{array}{r}\text { Electronic energy incl. ZPVE } \\
\text { in Hartees }\end{array}$ & $\begin{array}{r}\text { Relative energy in } \\
\mathrm{kcal} / \mathrm{mol}\end{array}$ \\
\hline M001 & $1.67 \mathrm{E}+04$ & $1.00 \mathrm{E}+06$ & -534.674067 & 1.77 \\
\hline M011 & $2.08 \mathrm{E}+04$ & $9.94 \mathrm{E}+05$ & -534.674906 & 1.24 \\
\hline M015 & $1.58 \mathrm{E}+04$ & $1.07 \mathrm{E}+06$ & -534.673752 & 1.97 \\
\hline M020 & $1.76 \mathrm{E}+04$ & $1.03 \mathrm{E}+06$ & -534.674682 & 1.38 \\
\hline M035 & $1.69 \mathrm{E}+04$ & $1.10 \mathrm{E}+06$ & -534.674908 & 1.24 \\
\hline M036 & $1.43 \mathrm{E}+04$ & $1.10 \mathrm{E}+06$ & -534.674559 & 1.46 \\
\hline M037 & $1.04 \mathrm{E}+04$ & $1.02 \mathrm{E}+06$ & -534.674988 & 1.19 \\
\hline M048 & $1.15 \mathrm{E}+04$ & $1.02 \mathrm{E}+06$ & -534.674565 & 1.46 \\
\hline M050 & $9.89 \mathrm{E}+03$ & $1.04 \mathrm{E}+06$ & -534.676653 & 0.15 \\
\hline M054 & $2.44 \mathrm{E}+04$ & $1.06 \mathrm{E}+06$ & -534.674911 & 1.24 \\
\hline M070 & $2.15 \mathrm{E}+04$ & $1.17 \mathrm{E}+06$ & -534.674918 & 1.23 \\
\hline M083 & $7.79 \mathrm{E}+03$ & $9.84 \mathrm{E}+05$ & -534.675994 & 0.56 \\
\hline M092 & $1.85 \mathrm{E}+04$ & $1.00 \mathrm{E}+06$ & -534.674807 & 1.30 \\
\hline M095 & $9.16 \mathrm{E}+03$ & $9.09 \mathrm{E}+05$ & -534.67587 & 0.64 \\
\hline M111 & $1.37 \mathrm{E}+04$ & $9.96 \mathrm{E}+05$ & -534.676885 & 0 \\
\hline M117 & $2.07 \mathrm{E}+04$ & $1.09 \mathrm{E}+06$ & -534.674329 & 1.60 \\
\hline M119 & $1.53 \mathrm{E}+04$ & $1.10 \mathrm{E}+06$ & -534.674383 & 1.57 \\
\hline M123 & $8.68 \mathrm{E}+03$ & $9.58 \mathrm{E}+05$ & -534.674717 & 1.36 \\
\hline M124 & $9.58 \mathrm{E}+03$ & $9.51 \mathrm{E}+05$ & -534.676824 & 0.04 \\
\hline M125 & $7.79 \mathrm{E}+03$ & $9.62 \mathrm{E}+05$ & -534.675482 & 0.88 \\
\hline M129 & $8.37 \mathrm{E}+03$ & $9.57 \mathrm{E}+05$ & -534.674357 & 1.59 \\
\hline M143 & $1.12 \mathrm{E}+04$ & $9.91 \mathrm{E}+05$ & -534.674639 & 1.41 \\
\hline M150 & $1.37 \mathrm{E}+04$ & $1.04 \mathrm{E}+06$ & -534.675077 & 1.13 \\
\hline M157 & $1.79 \mathrm{E}+04$ & $9.51 \mathrm{E}+05$ & -534.674872 & 1.26 \\
\hline M162 & $2.22 \mathrm{E}+04$ & $1.09 \mathrm{E}+06$ & -534.673387 & 2.20 \\
\hline M183 & $2.66 \mathrm{E}+04$ & $1.06 \mathrm{E}+06$ & -534.67401 & 1.80 \\
\hline M188 & $6.63 \mathrm{E}+03$ & $9.04 \mathrm{E}+05$ & -534.674828 & 1.29 \\
\hline M194 & $1.04 \mathrm{E}+04$ & $1.04 \mathrm{E}+06$ & -534.674861 & 1.27 \\
\hline M212 & $5.31 \mathrm{E}+03$ & $8.49 \mathrm{E}+05$ & -534.675472 & 0.89 \\
\hline M216 & $1.66 \mathrm{E}+04$ & $9.78 \mathrm{E}+05$ & -534.675398 & 0.93 \\
\hline M226 & $1.30 \mathrm{E}+04$ & $9.06 \mathrm{E}+05$ & -534.675402 & 0.93 \\
\hline M235 & $1.06 \mathrm{E}+04$ & $1.03 \mathrm{E}+06$ & -534.67606 & 0.52 \\
\hline M248 & $7.55 \mathrm{E}+03$ & $9.19 \mathrm{E}+05$ & -534.67578 & 0.69 \\
\hline M263 & $9.24 \mathrm{E}+03$ & $8.46 \mathrm{E}+05$ & -534.67582 & 0.67 \\
\hline M286 & $1.20 \mathrm{E}+04$ & $9.91 \mathrm{E}+05$ & -534.675488 & 0.88 \\
\hline M290 & $1.07 \mathrm{E}+04$ & $9.27 \mathrm{E}+05$ & -534.675767 & 0.70 \\
\hline M292 & $3.33 \mathrm{E}+04$ & $8.89 \mathrm{E}+05$ & -534.675377 & 0.95 \\
\hline$\$ B 898$ & $2.07 \mathrm{E}+04$ & $1.02 \mathrm{E}+06$ & -534.675785 & 0.69 \\
\hline M322 & $8.30 \mathrm{E}+03$ & $9.41 \mathrm{E}+05$ & -534.676192 & 0.43 \\
\hline M330 & $9.63 \mathrm{E}+03$ & $7.82 \mathrm{E}+05$ & -534.675413 & 0.92 \\
\hline M337 & $2.18 \mathrm{E}+04$ & $1.06 \mathrm{E}+06$ & -534.675064 & 1.14 \\
\hline
\end{tabular}




\begin{tabular}{|l|r|r|r|r|}
\hline M372 & $1.98 \mathrm{E}+04$ & $1.17 \mathrm{E}+06$ & -534.674754 & 1.34 \\
\hline M373 & $1.39 \mathrm{E}+04$ & $9.93 \mathrm{E}+05$ & -534.675706 & 0.74 \\
\hline M380 & $8.59 \mathrm{E}+03$ & $9.02 \mathrm{E}+05$ & -534.675244 & 1.03 \\
\hline M387 & $1.07 \mathrm{E}+04$ & $7.86 \mathrm{E}+05$ & -534.675367 & 0.95 \\
\hline M392 & $1.21 \mathrm{E}+04$ & $8.25 \mathrm{E}+05$ & -534.675354 & 0.96 \\
\hline M402 & $3.16 \mathrm{E}+03$ & $7.42 \mathrm{E}+05$ & -534.676346 & 0.34 \\
\hline M403 & $1.30 \mathrm{E}+04$ & $1.11 \mathrm{E}+06$ & -534.676659 & 0.14 \\
\hline M440 & $6.73 \mathrm{E}+03$ & $9.41 \mathrm{E}+05$ & -534.67444 & 1.53 \\
\hline M453 & $2.64 \mathrm{E}+03$ & $7.30 \mathrm{E}+05$ & -534.676777 & 0.07 \\
\hline M456 & $9.27 \mathrm{E}+03$ & $8.43 \mathrm{E}+05$ & -534.674672 & 1.39 \\
\hline M462 & $1.05 \mathrm{E}+04$ & $9.89 \mathrm{E}+05$ & -534.676516 & 0.23 \\
\hline M496 & $1.55 \mathrm{E}+04$ & $9.32 \mathrm{E}+05$ & -534.674611 & 1.43 \\
\hline M505 & $3.30 \mathrm{E}+04$ & $1.07 \mathrm{E}+06$ & -534.674139 & 1.72 \\
\hline M506 & $5.03 \mathrm{E}+03$ & $8.58 \mathrm{E}+05$ & -534.675254 & 1.02 \\
\hline M527 & $2.10 \mathrm{E}+03$ & $6.90 \mathrm{E}+05$ & -534.6762 & 0.43 \\
\hline M542 & $2.20 \mathrm{E}+03$ & $6.46 \mathrm{E}+05$ & -534.67638 & 0.32 \\
\hline M545 & $2.25 \mathrm{E}+04$ & $9.23 \mathrm{E}+05$ & -534.675854 & 0.65 \\
\hline M548 & $2.43 \mathrm{E}+03$ & $7.18 \mathrm{E}+05$ & -534.676316 & 0.36 \\
\hline
\end{tabular}


991 Table S7 Conformers of the transition state for the $\mathrm{C}_{6} \mathrm{H}_{9} \mathrm{O}_{4} 1,7 \mathrm{H}$-shift.

\begin{tabular}{|r|r|r|r|r|}
\hline $\begin{array}{l}\text { Conformer } \\
\text { number }\end{array}$ & $\begin{array}{r}\text { Vibrational partition } \\
\text { function }\end{array}$ & $\begin{array}{r}\text { Rotational partition } \\
\text { function }\end{array}$ & $\begin{array}{r}\text { Electronic energy incl. ZPVE } \\
\text { in Hartees }\end{array}$ & $\begin{array}{r}\text { Relative energy in } \\
\text { kcal/mol }\end{array}$ \\
\hline 107 & $1.21 \mathrm{E}+03$ & $7.52 \mathrm{E}+05$ & -534.651653 & 1.78 \\
\hline 152 & $1.35 \mathrm{E}+03$ & $7.57 \mathrm{E}+05$ & -534.652989 & 0.95 \\
\hline 172 & $1.15 \mathrm{E}+03$ & $7.10 \mathrm{E}+05$ & -534.652814 & 1.06 \\
\hline 177 & $1.89 \mathrm{E}+03$ & $7.79 \mathrm{E}+05$ & -534.652732 & 1.11 \\
\hline 19 & $5.77 \mathrm{E}+02$ & $7.05 \mathrm{E}+05$ & -534.652944 & 0.97 \\
\hline 1 & $7.27 \mathrm{E}+02$ & $6.75 \mathrm{E}+05$ & -534.650137 & 2.74 \\
\hline 249 & $2.09 \mathrm{E}+03$ & $7.68 \mathrm{E}+05$ & -534.647726 & 4.25 \\
\hline 25 & $6.24 \mathrm{E}+02$ & $7.27 \mathrm{E}+05$ & -534.654497 & 0 \\
\hline 274 & $6.65 \mathrm{E}+02$ & $6.68 \mathrm{E}+05$ & -534.647883 & 4.15 \\
\hline 285 & $5.39 \mathrm{E}+02$ & $6.67 \mathrm{E}+05$ & -534.647666 & 4.29 \\
\hline 4 & $5.35 \mathrm{E}+02$ & $7.10 \mathrm{E}+05$ & -534.648387 & 3.83 \\
\hline 91 & $9.95 \mathrm{E}+02$ & $7.38 \mathrm{E}+05$ & -534.647938 & 4.12 \\
\hline
\end{tabular}


Table S8 Conformers of the product for the $\mathrm{C}_{6} \mathrm{H}_{9} \mathrm{O}_{4} 1,7 \mathrm{H}$-shift and also the reactant of $\mathrm{C}_{6} \mathrm{H}_{9} \mathrm{O}_{4} \mathrm{CO}$ loss.

\begin{tabular}{|c|c|c|c|c|}
\hline $\begin{array}{l}\text { Conformer } \\
\text { number }\end{array}$ & $\begin{array}{r}\text { Vibrational partition } \\
\text { function }\end{array}$ & $\begin{array}{r}\text { Rotational partition } \\
\text { function }\end{array}$ & $\begin{array}{r}\text { Electronic energy incl. ZPVE } \\
\text { in Hartees }\end{array}$ & $\begin{array}{r}\begin{array}{r}\text { Relative energy in } \\
\mathrm{kcal} / \mathrm{mol}\end{array} \\
\end{array}$ \\
\hline M001 & $1.44 \mathrm{E}+04$ & $9.97 \mathrm{E}+05$ & -534.667011 & 1.72 \\
\hline M003 & $1.68 \mathrm{E}+04$ & $1.00 \mathrm{E}+06$ & -534.667312 & 1.53 \\
\hline M009 & $1.45 \mathrm{E}+04$ & $9.29 \mathrm{E}+05$ & -534.667125 & 1.65 \\
\hline M014 & $3.22 \mathrm{E}+04$ & $1.10 \mathrm{E}+06$ & -534.667077 & 1.68 \\
\hline M019 & $3.25 \mathrm{E}+04$ & $1.10 \mathrm{E}+06$ & -534.667180 & 1.61 \\
\hline M020 & $2.03 E+04$ & $1.01 \mathrm{E}+06$ & -534.667204 & 1.60 \\
\hline M025 & $2.27 \mathrm{E}+04$ & $1.04 \mathrm{E}+06$ & -534.667019 & 1.71 \\
\hline M035 & $4.59 \mathrm{E}+04$ & $1.19 \mathrm{E}+06$ & -534.666702 & 1.91 \\
\hline M043 & $2.40 \mathrm{E}+04$ & $1.11 \mathrm{E}+06$ & -534.666723 & 1.90 \\
\hline M069 & $2.62 \mathrm{E}+04$ & $1.10 \mathrm{E}+06$ & -534.666741 & 1.89 \\
\hline M086 & $2.63 \mathrm{E}+04$ & $1.10 \mathrm{E}+06$ & -534.666742 & 1.89 \\
\hline M129 & $2.43 \mathrm{E}+04$ & $1.00 \mathrm{E}+06$ & -534.666986 & 1.73 \\
\hline M133 & $2.25 \mathrm{E}+04$ & $1.04 \mathrm{E}+06$ & -534.666776 & 1.86 \\
\hline M146 & $3.71 \mathrm{E}+04$ & $1.18 \mathrm{E}+06$ & -534.666672 & 1.93 \\
\hline M147 & $2.11 \mathrm{E}+04$ & $1.08 \mathrm{E}+06$ & -534.666821 & 1.84 \\
\hline M148 & $1.28 \mathrm{E}+04$ & $9.35 \mathrm{E}+05$ & -534.669259 & 0.31 \\
\hline M167 & $1.25 \mathrm{E}+04$ & $9.48 \mathrm{E}+05$ & -534.668303 & 0.91 \\
\hline M173 & $9.13 \mathrm{E}+03$ & $9.54 \mathrm{E}+05$ & -534.667595 & 1.35 \\
\hline M181 & $8.65 \mathrm{E}+03$ & $1.02 \mathrm{E}+06$ & -534.668384 & 0.86 \\
\hline M192 & $9.63 \mathrm{E}+03$ & $9.80 \mathrm{E}+05$ & -534.668818 & 0.58 \\
\hline M209 & $5.43 \mathrm{E}+03$ & $7.60 \mathrm{E}+05$ & -534.668914 & 0.52 \\
\hline M212 & $2.79 \mathrm{E}+04$ & $1.02 \mathrm{E}+06$ & -534.6666695 & 1.92 \\
\hline M227 & $3.19 \mathrm{E}+04$ & $9.99 \mathrm{E}+05$ & -534.666609 & 1.97 \\
\hline M246 & $1.69 \mathrm{E}+04$ & $1.03 \mathrm{E}+06$ & -534.666429 & 2.08 \\
\hline M265 & $5.81 \mathrm{E}+03$ & $7.86 \mathrm{E}+05$ & -534.668635 & 0.70 \\
\hline M273 & $1.14 \mathrm{E}+04$ & $1.02 \mathrm{E}+06$ & -534.666622 & 1.96 \\
\hline M314 & $1.52 \mathrm{E}+04$ & $1.03 \mathrm{E}+06$ & -534.6665885 & 1.98 \\
\hline M338 & $5.34 \mathrm{E}+03$ & $7.66 \mathrm{E}+05$ & -534.669026 & 0.45 \\
\hline M346 & $2.25 \mathrm{E}+04$ & $1.04 \mathrm{E}+06$ & -534.666775 & 1.87 \\
\hline M386 & $2.34 \mathrm{E}+03$ & $7.26 \mathrm{E}+05$ & -534.669748 & 0 \\
\hline M390 & $2.73 \mathrm{E}+04$ & $1.05 \mathrm{E}+06$ & -534.666837 & 1.83 \\
\hline M539 & $1.22 \mathrm{E}+04$ & $8.25 \mathrm{E}+05$ & -534.668904 & 0.53 \\
\hline M547 & $1.14 \mathrm{E}+04$ & $1.01 \mathrm{E}+06$ & -534.669464 & 0.18 \\
\hline M675 & $1.39 \mathrm{E}+04$ & $9.10 \mathrm{E}+05$ & -534.668110 & 1.03 \\
\hline
\end{tabular}


997 Table $\mathbf{S 9}$ Conformers of the transition state of $\mathrm{C}_{6} \mathrm{H}_{9} \mathrm{O}_{4} \mathrm{CO}$ loss.

\begin{tabular}{|l|r|r|r|r|}
\hline $\begin{array}{l}\text { Conformer } \\
\text { number }\end{array}$ & $\begin{array}{r}\text { Vibrational partition } \\
\text { function }\end{array}$ & $\begin{array}{r}\text { Rotational partition } \\
\text { function }\end{array}$ & $\begin{array}{r}\text { Electronic energy incl. ZPVE } \\
\text { in Hartees }\end{array}$ & $\begin{array}{r}\text { Relative energy in } \\
\text { kcal/mol }\end{array}$ \\
\hline M01 & $2.35 \mathrm{E}+04$ & $8.17 \mathrm{E}+05$ & -534.643885 & 0.44 \\
\hline M03 & $1.67 \mathrm{E}+04$ & $8.27 \mathrm{E}+05$ & -534.643456 & 0.71 \\
\hline M09 & $1.04 \mathrm{E}+04$ & $8.40 \mathrm{E}+05$ & -534.642906 & 1.05 \\
\hline M10 & $4.81 \mathrm{E}+04$ & $8.74 \mathrm{E}+05$ & -534.642020 & 1.61 \\
\hline M12 & $2.42 \mathrm{E}+04$ & $8.01 \mathrm{E}+05$ & -534.642863 & 1.08 \\
\hline M13- & $1.35 \mathrm{E}+04$ & $9.23 \mathrm{E}+05$ & -534.644017 & 0.36 \\
\hline M14 & $1.80 \mathrm{E}+04$ & $9.04 \mathrm{E}+05$ & -534.644586 & 0 \\
\hline M17 & $1.35 \mathrm{E}+04$ & $9.23 \mathrm{E}+05$ & -534.644018 & 0.36 \\
\hline M21 & $2.34 \mathrm{E}+04$ & $9.55 \mathrm{E}+05$ & -534.643479 & 0.69 \\
\hline M25 & $3.24 \mathrm{E}+04$ & $1.01 \mathrm{E}+06$ & -534.644118 & 0.29 \\
\hline M27 & $6.16 \mathrm{E}+04$ & $1.02 \mathrm{E}+06$ & -534.642474 & 1.33 \\
\hline M28 & $2.17 \mathrm{E}+04$ & $9.82 \mathrm{E}+05$ & -534.644304 & 0.18 \\
\hline M43 & $1.09 \mathrm{E}+04$ & $8.58 \mathrm{E}+05$ & -534.643170 & 0.89 \\
\hline M44 & $1.35 \mathrm{E}+04$ & $8.80 \mathrm{E}+05$ & -534.642984 & 1.01 \\
\hline M53- & $7.25 \mathrm{E}+04$ & $9.79 \mathrm{E}+05$ & -534.642253 & 1.46 \\
\hline M63 & $2.04 \mathrm{E}+05$ & $1.21 \mathrm{E}+06$ & -534.641669 & 1.83 \\
\hline M67 & $4.55 \mathrm{E}+04$ & $1.10 \mathrm{E}+06$ & -534.643355 & 0.77 \\
\hline M70 & $8.26 \mathrm{E}+04$ & $1.03 \mathrm{E}+06$ & -534.641673 & 1.83 \\
\hline M74- & $6.38 \mathrm{E}+04$ & $1.16 \mathrm{E}+06$ & -534.641783 & 1.76 \\
\hline M75 & $1.18 \mathrm{E}+05$ & $1.14 \mathrm{E}+06$ & -534.640900 & 2.31 \\
\hline
\end{tabular}


1000 Table S10 Conformers of the reactant for the $\mathrm{C}_{6} \mathrm{H}_{9} \mathrm{O}_{6} 1,8 \mathrm{H}$-shift and 1,7 H-shift.

\begin{tabular}{|l|r|r|r|r|}
\hline $\begin{array}{l}\text { Conformer } \\
\text { number }\end{array}$ & $\begin{array}{r}\text { Vibrational partition } \\
\text { function }\end{array}$ & $\begin{array}{r}\text { Rotational partition } \\
\text { function }\end{array}$ & $\begin{array}{r}\text { Electronic energy incl. ZPVE } \\
\text { in Hartees }\end{array}$ & $\begin{array}{r}\text { Relative energy in } \\
\text { kcal/mol }\end{array}$ \\
\hline M012 & $4.84 \mathrm{E}+04$ & $1.47 \mathrm{E}+06$ & -685.049415 & 1.77 \\
\hline M032 & $2.61 \mathrm{E}+04$ & $1.26 \mathrm{E}+06$ & -685.051564 & 0.42 \\
\hline M039 & $1.36 \mathrm{E}+04$ & $1.36 \mathrm{E}+06$ & -685.050459 & 1.12 \\
\hline M043 & $1.19 \mathrm{E}+04$ & $1.36 \mathrm{E}+06$ & -685.051868 & 0.23 \\
\hline M066 & $1.70 \mathrm{E}+04$ & $1.53 \mathrm{E}+06$ & -685.050893 & 0.84 \\
\hline M071 & $1.84 \mathrm{E}+04$ & $1.52 \mathrm{E}+06$ & -685.052093 & 0.09 \\
\hline M087 & $2.83 \mathrm{E}+04$ & $1.53 \mathrm{E}+06$ & -685.051497 & 0.47 \\
\hline M121 & $7.95 \mathrm{E}+04$ & $1.78 \mathrm{E}+06$ & -685.05018 & 1.29 \\
\hline M222 & $1.50 \mathrm{E}+05$ & $1.97 \mathrm{E}+06$ & -685.048624 & 2.27 \\
\hline M227 & $6.77 \mathrm{E}+04$ & $1.93 \mathrm{E}+06$ & -685.049899 & 1.47 \\
\hline M273 & $2.51 \mathrm{E}+04$ & $1.50 \mathrm{E}+06$ & -685.050332 & 1.20 \\
\hline M329 & $7.31 \mathrm{E}+04$ & $1.61 \mathrm{E}+06$ & -685.0509 & 0.84 \\
\hline M372 & $2.67 \mathrm{E}+05$ & $2.08 \mathrm{E}+06$ & -685.0485 & 2.35 \\
\hline M385 & $5.68 \mathrm{E}+04$ & $1.77 \mathrm{E}+06$ & -685.050996 & 0.78 \\
\hline M387 & $7.26 \mathrm{E}+04$ & $1.94 \mathrm{E}+06$ & -685.047824 & 2.77 \\
\hline M528 & $1.73 \mathrm{E}+05$ & $1.85 \mathrm{E}+06$ & -685.048334 & 2.45 \\
\hline M546 & $2.33 \mathrm{E}+05$ & $1.87 \mathrm{E}+06$ & -685.048301 & 2.47 \\
\hline M572 & $2.12 \mathrm{E}+04$ & $1.23 \mathrm{E}+06$ & -685.052239 & 0 \\
\hline M666 & $5.87 \mathrm{E}+04$ & $1.57 \mathrm{E}+06$ & -685.050473 & 1.11 \\
\hline M703 & $1.04 \mathrm{E}+05$ & $1.84 \mathrm{E}+06$ & -685.048644 & 2.26 \\
\hline M961 & $1.88 \mathrm{E}+05$ & $2.07 \mathrm{E}+06$ & -685.049039 & 2.01 \\
\hline
\end{tabular}


1003 Table S11 Conformers of the transition state for the $\mathrm{C}_{6} \mathrm{H}_{9} \mathrm{O}_{6} 1,8 \mathrm{H}$-shift.

\begin{tabular}{|l|r|r|r|r|}
\hline $\begin{array}{l}\text { Conformer } \\
\text { number }\end{array}$ & $\begin{array}{r}\text { Vibrational partition } \\
\text { function }\end{array}$ & $\begin{array}{r}\text { Rotational partition } \\
\text { function }\end{array}$ & $\begin{array}{r}\text { Electronic energy incl. ZPVE } \\
\text { in Hartees }\end{array}$ & $\begin{array}{r}\text { Relative energy in } \\
\mathrm{kcal} / \mathrm{mol}\end{array}$ \\
\hline M114 & $3.12 \mathrm{E}+03$ & $1.23 \mathrm{E}+06$ & -685.028291 & 1.35 \\
\hline M189 & $3.16 \mathrm{E}+03$ & $1.30 \mathrm{E}+06$ & -685.030442 & 0 \\
\hline M220 & $2.46 \mathrm{E}+03$ & $1.20 \mathrm{E}+06$ & -685.028390 & 1.29 \\
\hline M266 & $1.43 \mathrm{E}+03$ & $9.86 \mathrm{E}+05$ & -685.027391 & 1.91 \\
\hline M341 & $1.76 \mathrm{E}+03$ & $1.01 \mathrm{E}+06$ & -685.028846 & 1.00 \\
\hline M369 & $3.88 \mathrm{E}+03$ & $1.26 \mathrm{E}+06$ & -685.029924 & 0.33 \\
\hline M400 & $3.02 \mathrm{E}+03$ & $1.29 \mathrm{E}+06$ & -685.028979 & 0.92 \\
\hline M482 & $3.04 \mathrm{E}+03$ & $1.24 \mathrm{E}+06$ & -685.028666 & 1.11 \\
\hline M693 & $1.88 \mathrm{E}+03$ & $1.18 \mathrm{E}+06$ & -685.027469 & 1.87 \\
\hline
\end{tabular}

Table S12 Conformers of the transition state for the $\mathrm{C}_{6} \mathrm{H}_{9} \mathrm{O}_{6} 1,7 \mathrm{H}$-shift.

\begin{tabular}{|l|r|r|r|r|}
\hline $\begin{array}{l}\text { Conformer } \\
\text { number }\end{array}$ & $\begin{array}{r}\text { Vibrational partition } \\
\text { function }\end{array}$ & $\begin{array}{r}\text { Rotational partition } \\
\text { function }\end{array}$ & $\begin{array}{r}\text { Electronic energy incl. ZPVE } \\
\text { in Hartees }\end{array}$ & $\begin{array}{r}\text { Relative energy in } \\
\mathrm{kcal} / \mathrm{mol}\end{array}$ \\
\hline M031 & $2.50 \mathrm{E}+03$ & $1.09 \mathrm{E}+06$ & -685.030071 & 0 \\
\hline M034 & $2.50 \mathrm{E}+03$ & $1.09 \mathrm{E}+06$ & -685.030070 & 0.00 \\
\hline M061 & $2.75 \mathrm{E}+03$ & $1.18 \mathrm{E}+06$ & -685.029012 & 0.66 \\
\hline M064 & $4.11 \mathrm{E}+03$ & $1.16 \mathrm{E}+06$ & -685.026928 & 1.97 \\
\hline M076 & $4.97 \mathrm{E}+03$ & $1.20 \mathrm{E}+06$ & -685.025618 & 2.79 \\
\hline M080 & $4.11 \mathrm{E}+03$ & $1.16 \mathrm{E}+06$ & -685.026929 & 1.97 \\
\hline M151 & $3.36 \mathrm{E}+03$ & $1.13 \mathrm{E}+06$ & -685.027051 & 1.90 \\
\hline
\end{tabular}


1010 Table S13 Conformers of the product for the $\mathrm{C}_{6} \mathrm{H}_{9} \mathrm{O}_{6} 1,8 \mathrm{H}$-shift and reactant for the $\mathrm{C}_{6} \mathrm{H}_{9} \mathrm{O}_{6} \mathrm{CO}$ loss.

\begin{tabular}{|c|c|c|c|c|}
\hline $\begin{array}{l}\text { Conformer } \\
\text { number }\end{array}$ & $\begin{array}{r}\text { Vibrational partition } \\
\text { function } \\
\end{array}$ & $\begin{array}{r}\text { Rotational partition } \\
\text { function } \\
\end{array}$ & $\begin{array}{r}\text { Electronic energy incl. ZPVE } \\
\text { in Hartees }\end{array}$ & $\begin{array}{r}\begin{array}{r}\text { Relative energy in } \\
\mathrm{kcal} / \mathrm{mol}\end{array} \\
\end{array}$ \\
\hline M004 & $1.97 \mathrm{E}+05$ & $1.72 \mathrm{E}+06$ & -685.056826 & 1.04 \\
\hline M013 & $2.38 \mathrm{E}+05$ & $1.77 \mathrm{E}+06$ & -685.057240 & 0.78 \\
\hline M017 & $1.18 \mathrm{E}+05$ & $1.54 \mathrm{E}+06$ & -685.058315 & 0.11 \\
\hline M018 & $1.18 \mathrm{E}+05$ & $1.54 \mathrm{E}+06$ & -685.058316 & 0.11 \\
\hline M020 & $1.18 \mathrm{E}+05$ & $1.82 \mathrm{E}+06$ & -685.058486 & 0 \\
\hline M024 & $7.86 \mathrm{E}+05$ & $2.09 \mathrm{E}+06$ & -685.052147 & 3.98 \\
\hline M027 & $1.42 \mathrm{E}+05$ & $1.83 \mathrm{E}+06$ & -685.057552 & 0.59 \\
\hline M028 & $1.10 \mathrm{E}+05$ & $1.49 \mathrm{E}+06$ & -685.057268 & 0.76 \\
\hline M041 & $3.12 \mathrm{E}+05$ & $1.78 \mathrm{E}+06$ & -685.055345 & 1.97 \\
\hline M049 & $4.86 \mathrm{E}+05$ & $1.96 \mathrm{E}+06$ & -685.055532 & 1.85 \\
\hline M051 & $2.43 \mathrm{E}+05$ & $1.91 \mathrm{E}+06$ & -685.057042 & 0.91 \\
\hline M052 & $3.21 \mathrm{E}+05$ & $1.82 \mathrm{E}+06$ & -685.056130 & 1.48 \\
\hline M059 & $1.20 \mathrm{E}+05$ & $1.69 \mathrm{E}+06$ & -685.055747 & 1.72 \\
\hline M064 & $1.64 \mathrm{E}+05$ & $1.69 \mathrm{E}+06$ & -685.056849 & 1.03 \\
\hline M075 & $1.49 \mathrm{E}+05$ & $1.72 \mathrm{E}+06$ & -685.056637 & 1.16 \\
\hline M079 & $1.41 \mathrm{E}+05$ & $1.69 \mathrm{E}+06$ & -685.056786 & 1.07 \\
\hline M100 & $1.74 \mathrm{E}+05$ & $1.94 \mathrm{E}+06$ & -685.048537 & 6.24 \\
\hline M130 & $1.95 \mathrm{E}+05$ & $1.97 \mathrm{E}+06$ & -685.047048 & 7.18 \\
\hline M132 & $2.20 \mathrm{E}+05$ & $2.09 \mathrm{E}+06$ & -685.048944 & 5.99 \\
\hline M144 & $1.80 \mathrm{E}+05$ & $1.99 \mathrm{E}+06$ & -685.048677 & 6.16 \\
\hline M161 & $1.47 \mathrm{E}+05$ & $1.74 \mathrm{E}+06$ & -685.048367 & 6.35 \\
\hline M182 & $2.19 \mathrm{E}+04$ & $1.54 \mathrm{E}+06$ & -685.050543 & 4.98 \\
\hline M187 & $1.90 \mathrm{E}+05$ & $2.00 \mathrm{E}+06$ & -685.046868 & 7.29 \\
\hline M191 & $2.78 \mathrm{E}+04$ & $1.35 \mathrm{E}+06$ & -685.056543 & 1.22 \\
\hline M205 & $1.38 \mathrm{E}+05$ & $1.82 \mathrm{E}+06$ & -685.049251 & 5.80 \\
\hline M221 & $1.64 \mathrm{E}+05$ & $1.81 \mathrm{E}+06$ & -685.048094 & 6.52 \\
\hline M223 & $1.40 \mathrm{E}+05$ & $1.79 \mathrm{E}+06$ & -685.048408 & 6.32 \\
\hline M246 & $1.61 \mathrm{E}+05$ & $1.86 \mathrm{E}+06$ & -685.048799 & 6.08 \\
\hline M263 & $1.83 \mathrm{E}+05$ & $1.87 \mathrm{E}+06$ & -685.049539 & 5.61 \\
\hline M303 & $1.49 \mathrm{E}+05$ & $1.85 \mathrm{E}+06$ & -685.048705 & 6.14 \\
\hline M388 & $1.88 \mathrm{E}+05$ & $1.64 \mathrm{E}+06$ & -685.049116 & 5.88 \\
\hline M407 & $2.44 \mathrm{E}+05$ & $1.81 \mathrm{E}+06$ & -685.048620 & 6.19 \\
\hline M413 & $2.85 \mathrm{E}+04$ & $1.30 \mathrm{E}+06$ & -685.057673 & 0.51 \\
\hline M428 & $1.50 \mathrm{E}+05$ & $1.62 \mathrm{E}+06$ & -685.048623 & 6.19 \\
\hline M454 & $1.41 \mathrm{E}+05$ & $1.65 \mathrm{E}+06$ & -685.048327 & 6.37 \\
\hline M487 & $1.36 \mathrm{E}+05$ & $1.75 \mathrm{E}+06$ & -685.048356 & 6.36 \\
\hline M503 & $1.29 \mathrm{E}+05$ & $1.85 \mathrm{E}+06$ & -685.048663 & 6.16 \\
\hline M505 & $1.72 \mathrm{E}+04$ & $1.26 \mathrm{E}+06$ & -685.049405 & 5.70 \\
\hline M507 & $1.92 \mathrm{E}+04$ & $1.27 \mathrm{E}+06$ & -685.049954 & 5.35 \\
\hline M547 & $1.66 \mathrm{E}+04$ & $1.36 \mathrm{E}+06$ & -685.049022 & 5.94 \\
\hline M550 & $9.70 \mathrm{E}+03$ & $1.21 \mathrm{E}+06$ & -685.049190 & 5.83 \\
\hline
\end{tabular}




\begin{tabular}{|c|c|c|c|c|}
\hline M584 & $3.52 \mathrm{E}+04$ & $1.23 \mathrm{E}+06$ & -685.049417 & 5.69 \\
\hline M618 & $1.66 \mathrm{E}+04$ & $1.36 \mathrm{E}+06$ & -685.049023 & 5.94 \\
\hline M657 & $1.57 \mathrm{E}+04$ & $1.21 \mathrm{E}+06$ & -685.049757 & 5.48 \\
\hline M004 & $5.73 \mathrm{E}+04$ & $1.39 \mathrm{E}+06$ & -685.056436 & 1.29 \\
\hline M011 & $7.22 \mathrm{E}+04$ & $1.36 \mathrm{E}+06$ & -685.056814 & 1.05 \\
\hline M021 & $1.50 \mathrm{E}+05$ & $1.52 \mathrm{E}+06$ & -685.055627 & 1.79 \\
\hline M034 & $2.39 \mathrm{E}+04$ & $1.77 \mathrm{E}+06$ & -685.054497 & 2.50 \\
\hline M035 & $2.67 \mathrm{E}+04$ & $1.40 \mathrm{E}+06$ & -685.056324 & 1.36 \\
\hline M042 & $1.74 \mathrm{E}+05$ & $1.87 \mathrm{E}+06$ & -685.056164 & 1.46 \\
\hline M055 & $1.95 \mathrm{E}+05$ & $1.79 \mathrm{E}+06$ & -685.055014 & 2.18 \\
\hline M059 & $2.84 \mathrm{E}+05$ & $1.81 \mathrm{E}+06$ & -685.056181 & 1.45 \\
\hline M064 & $2.71 \mathrm{E}+05$ & $1.78 \mathrm{E}+06$ & -685.055851 & 1.65 \\
\hline M083 & $2.00 \mathrm{E}+05$ & $1.68 \mathrm{E}+06$ & -685.055878 & 1.64 \\
\hline M096 & $2.40 \mathrm{E}+05$ & $1.87 \mathrm{E}+06$ & -685.056383 & 1.32 \\
\hline M100 & $2.90 \mathrm{E}+05$ & $1.87 \mathrm{E}+06$ & -685.056614 & 1.17 \\
\hline M109 & $1.70 \mathrm{E}+05$ & $1.82 \mathrm{E}+06$ & -685.058029 & 0.29 \\
\hline M146 & $7.12 \mathrm{E}+04$ & $1.52 \mathrm{E}+06$ & -685.057848 & 0.40 \\
\hline M161 & $3.62 \mathrm{E}+05$ & $2.07 \mathrm{E}+06$ & -685.057066 & 0.89 \\
\hline M163 & $2.59 \mathrm{E}+05$ & $2.07 \mathrm{E}+06$ & -685.057312 & 0.74 \\
\hline M174 & $2.45 \mathrm{E}+04$ & $1.95 \mathrm{E}+06$ & -685.057178 & 0.82 \\
\hline M272 & $4.10 \mathrm{E}+05$ & $1.73 \mathrm{E}+06$ & -685.056722 & 1.11 \\
\hline M303 & $2.21 \mathrm{E}+05$ & $1.86 \mathrm{E}+06$ & -685.058152 & 0.21 \\
\hline M350 & $2.06 \mathrm{E}+05$ & $1.82 \mathrm{E}+06$ & -685.056596 & 1.19 \\
\hline M420 & $1.93 \mathrm{E}+05$ & $1.88 \mathrm{E}+06$ & -685.057483 & 0.63 \\
\hline M516 & $3.00 \mathrm{E}+05$ & $1.90 \mathrm{E}+06$ & -685.056702 & 1.12 \\
\hline M598 & $8.96 \mathrm{E}+04$ & $1.49 \mathrm{E}+06$ & -685.057899 & 0.37 \\
\hline M622 & $1.75 \mathrm{E}+05$ & $1.55 \mathrm{E}+06$ & -685.057870 & 0.39 \\
\hline M748 & $2.25 \mathrm{E}+05$ & $1.93 \mathrm{E}+06$ & -685.055852 & 1.65 \\
\hline M808 & $2.04 \mathrm{E}+05$ & $1.78 \mathrm{E}+06$ & -685.056119 & 1.49 \\
\hline M856 & $2.03 \mathrm{E}+05$ & $1.75 \mathrm{E}+06$ & -685.055899 & 1.62 \\
\hline M914 & $1.73 E+05$ & $1.83 \mathrm{E}+06$ & -685.056491 & 1.25 \\
\hline
\end{tabular}


1013 Table $\mathbf{S 1 4}$ Conformers of the product for the $\mathrm{C}_{6} \mathrm{H}_{9} \mathrm{O}_{6} 1,7 \mathrm{H}$-shift.

\begin{tabular}{|l|r|r|r|r|}
\hline $\begin{array}{l}\text { Conformer } \\
\text { number }\end{array}$ & $\begin{array}{r}\text { Vibrational partition } \\
\text { function }\end{array}$ & $\begin{array}{r}\text { Rotational partition } \\
\text { function }\end{array}$ & $\begin{array}{r}\text { Electronic energy incl. ZPVE } \\
\text { in Hartees }\end{array}$ & $\begin{array}{r}\text { Relative energy in } \\
\mathrm{kcal} / \mathrm{mol}\end{array}$ \\
\hline M006 & $2.82 \mathrm{E}+04$ & $1.22 \mathrm{E}+06$ & -685.071137 & 3.32 \\
\hline M042 & $2.38 \mathrm{E}+03$ & $9.79 \mathrm{E}+05$ & -685.073271 & 1.98 \\
\hline M044 & $6.60 \mathrm{E}+04$ & $1.49 \mathrm{E}+06$ & -685.076425 & 0.00 \\
\hline M132 & $1.51 \mathrm{E}+05$ & $1.81 \mathrm{E}+06$ & -685.074789 & 1.03 \\
\hline M059 & $1.61 \mathrm{E}+04$ & $1.03 \mathrm{E}+06$ & -685.072684 & 2.35 \\
\hline M104 & $1.89 \mathrm{E}+04$ & $1.12 \mathrm{E}+06$ & -685.070558 & 3.68 \\
\hline
\end{tabular}


1017 Table $\mathbf{S 1 5}$ Conformers of the transition state for the $\mathrm{C}_{6} \mathrm{H}_{9} \mathrm{O}_{6} \mathrm{CO}$ loss.

\begin{tabular}{|c|c|c|c|c|}
\hline $\begin{array}{l}\text { Conformer } \\
\text { number }\end{array}$ & $\begin{array}{r}\text { Vibrational partition } \\
\text { function } \\
\end{array}$ & $\begin{array}{r}\text { Rotational partition } \\
\text { function } \\
\end{array}$ & $\begin{array}{r}\text { Electronic energy incl. ZPVE } \\
\text { in Hartees } \\
\end{array}$ & $\begin{array}{r}\text { Relative energy in } \\
\mathrm{kcal} / \mathrm{mol}\end{array}$ \\
\hline M002 & $9.69 \mathrm{E}+04$ & $1.40 \mathrm{E}+06$ & -685.043171 & 0.52 \\
\hline M003 & $1.80 \mathrm{E}+06$ & $2.01 \mathrm{E}+06$ & -685.040855 & 1.97 \\
\hline M004 & $8.64 \mathrm{E}+05$ & $2.24 \mathrm{E}+06$ & -685.043070 & 0.58 \\
\hline M005 & $6.26 \mathrm{E}+05$ & $2.09 \mathrm{E}+06$ & -685.042810 & 0.74 \\
\hline M006 & $6.72 \mathrm{E}+04$ & $1.32 \mathrm{E}+06$ & -685.041896 & 1.32 \\
\hline M008 & $6.91 \mathrm{E}+05$ & $2.07 \mathrm{E}+06$ & -685.042621 & 0.86 \\
\hline M010 & $6.81 \mathrm{E}+05$ & $1.98 \mathrm{E}+06$ & -685.042989 & 0.63 \\
\hline M013 & $7.20 \mathrm{E}+05$ & $2.24 \mathrm{E}+06$ & -685.042784 & 0.76 \\
\hline M014 & $4.39 \mathrm{E}+05$ & $1.70 \mathrm{E}+06$ & -685.041682 & 1.45 \\
\hline M005 & $5.31 \mathrm{E}+05$ & $1.92 \mathrm{E}+06$ & -685.042297 & 1.07 \\
\hline M007 & $8.07 \mathrm{E}+05$ & $1.92 \mathrm{E}+06$ & -685.041468 & 1.59 \\
\hline M009 & $5.92 \mathrm{E}+05$ & $1.69 \mathrm{E}+06$ & -685.041388 & 1.64 \\
\hline M011 & $4.82 \mathrm{E}+05$ & $1.64 \mathrm{E}+06$ & -685.042254 & 1.09 \\
\hline M012 & $8.98 \mathrm{E}+05$ & $1.79 \mathrm{E}+06$ & -685.040994 & 1.88 \\
\hline M033 & $5.36 \mathrm{E}+04$ & $1.46 \mathrm{E}+06$ & -685.043997 & 0 \\
\hline M034 & $7.38 \mathrm{E}+04$ & $1.50 \mathrm{E}+06$ & -685.043714 & 0.18 \\
\hline M034 & $1.14 \mathrm{E}+05$ & $1.62 \mathrm{E}+06$ & -685.042345 & 1.04 \\
\hline M040 & $4.29 \mathrm{E}+05$ & $1.71 \mathrm{E}+06$ & -685.042109 & 1.18 \\
\hline M041 & $8.13 \mathrm{E}+05$ & $1.93 \mathrm{E}+06$ & -685.041837 & 1.36 \\
\hline M049 & $3.89 \mathrm{E}+05$ & $1.96 \mathrm{E}+06$ & -685.043252 & 0.47 \\
\hline M050 & $5.60 \mathrm{E}+05$ & $1.87 \mathrm{E}+06$ & -685.041634 & 1.48 \\
\hline M075 & $7.49 \mathrm{E}+05$ & $1.90 \mathrm{E}+06$ & -685.042089 & 1.20 \\
\hline M089 & $4.05 \mathrm{E}+05$ & $1.90 \mathrm{E}+06$ & -685.043021 & 0.61 \\
\hline M095 & $6.70 \mathrm{E}+05$ & $2.05 \mathrm{E}+06$ & -685.042853 & 0.72 \\
\hline M117 & $6.73 \mathrm{E}+05$ & $1.75 \mathrm{E}+06$ & -685.042985 & 0.64 \\
\hline M142 & $5.97 \mathrm{E}+05$ & $1.90 \mathrm{E}+06$ & -685.042611 & 0.87 \\
\hline M160 & $1.08 \mathrm{E}+06$ & $1.84 \mathrm{E}+06$ & -685.041696 & 1.44 \\
\hline M161 & $5.98 \mathrm{E}+05$ & $1.90 \mathrm{E}+06$ & -685.042612 & 0.87 \\
\hline M190 & $4.05 \mathrm{E}+05$ & $1.90 \mathrm{E}+06$ & -685.043020 & 0.61 \\
\hline M211 & $1.08 \mathrm{E}+06$ & $1.84 \mathrm{E}+06$ & -685.041698 & 1.44 \\
\hline M231 & $8.06 \mathrm{E}+05$ & $2.01 \mathrm{E}+06$ & -685.042063 & 1.21 \\
\hline M246 & $4.02 \mathrm{E}+05$ & $1.71 \mathrm{E}+06$ & -685.043537 & 0.29 \\
\hline M258 & $6.95 \mathrm{E}+05$ & $2.01 \mathrm{E}+06$ & -685.042522 & 0.93 \\
\hline M259 & $5.00 \mathrm{E}+05$ & $2.03 \mathrm{E}+06$ & -685.042321 & 1.05 \\
\hline M265 & $1.14 \mathrm{E}+06$ & $1.79 \mathrm{E}+06$ & -685.042959 & 0.65 \\
\hline M298 & $6.26 \mathrm{E}+05$ & $1.67 \mathrm{E}+06$ & -685.042323 & 1.05 \\
\hline M303 & $7.20 \mathrm{E}+05$ & $2.24 \mathrm{E}+06$ & -685.042784 & 0.76 \\
\hline M328 & $5.98 \mathrm{E}+05$ & $1.68 \mathrm{E}+06$ & -685.041474 & 1.58 \\
\hline M339 & $7.39 \mathrm{E}+05$ & $1.77 \mathrm{E}+06$ & -685.042011 & 1.25 \\
\hline M340 & $1.79 \mathrm{E}+06$ & $2.04 \mathrm{E}+06$ & -685.041850 & 1.35 \\
\hline M375 & $9.36 \mathrm{E}+05$ & $2.08 \mathrm{E}+06$ & -685.042573 & 0.89 \\
\hline
\end{tabular}




\begin{tabular}{|l|r|r|r|r|}
\hline M386 & $3.84 \mathrm{E}+05$ & $1.99 \mathrm{E}+06$ & -685.042931 & 0.67 \\
\hline M429 & $4.06 \mathrm{E}+05$ & $1.74 \mathrm{E}+06$ & -685.043041 & 0.60 \\
\hline M433 & $5.91 \mathrm{E}+05$ & $1.70 \mathrm{E}+06$ & -685.042846 & 0.72 \\
\hline M434 & $4.82 \mathrm{E}+05$ & $2.01 \mathrm{E}+06$ & -685.043485 & 0.32 \\
\hline M460 & $6.60 \mathrm{E}+05$ & $2.02 \mathrm{E}+06$ & -685.043085 & 0.57 \\
\hline M462 & $4.11 \mathrm{E}+05$ & $1.67 \mathrm{E}+06$ & -685.042585 & 0.89 \\
\hline M487 & $1.24 \mathrm{E}+05$ & $1.44 \mathrm{E}+06$ & -685.042210 & 1.12 \\
\hline M509 & $8.81 \mathrm{E}+05$ & $1.94 \mathrm{E}+06$ & -685.042302 & 1.06 \\
\hline M538 & $6.69 \mathrm{E}+05$ & $1.84 \mathrm{E}+06$ & -685.042632 & 0.86 \\
\hline M580 & $4.34 \mathrm{E}+05$ & $2.01 \mathrm{E}+06$ & -685.043748 & 0.16 \\
\hline M581 & $6.29 \mathrm{E}+05$ & $1.71 \mathrm{E}+06$ & -685.043602 & 0.25 \\
\hline M588 & $6.97 \mathrm{E}+05$ & $1.72 \mathrm{E}+06$ & -685.043358 & 0.40 \\
\hline M613 & $8.63 \mathrm{E}+04$ & $1.43 \mathrm{E}+06$ & -685.043395 & 0.38 \\
\hline M734 & $6.10 \mathrm{E}+05$ & $1.97 \mathrm{E}+06$ & -685.042873 & 0.71 \\
\hline M790 & $4.10 \mathrm{E}+05$ & $1.65 \mathrm{E}+06$ & -685.043187 & 0.51 \\
\hline
\end{tabular}


1020 Table S16 Conformers of the reactant for the $\mathrm{C}_{6} \mathrm{H}_{9} \mathrm{O}_{8} 1,7 \mathrm{H}$-shift, 1.4 H-shift, 1,5 H-shift and 1,6 H-shift.

\begin{tabular}{|c|c|c|c|c|}
\hline $\begin{array}{l}\text { Conformer } \\
\text { number }\end{array}$ & $\begin{array}{r}\text { Vibrational partition } \\
\text { function }\end{array}$ & $\begin{array}{r}\text { Rotational partition } \\
\text { function }\end{array}$ & $\begin{array}{r}\text { Electronic energy incl. ZPVE } \\
\text { in Hartees }\end{array}$ & $\begin{array}{r}\begin{array}{r}\text { Relative energy in } \\
\mathrm{kcal} / \mathrm{mol}\end{array} \\
\end{array}$ \\
\hline M017 & $5.09 \mathrm{E}+05$ & $2.15 \mathrm{E}+06$ & -835.435129 & 0.40 \\
\hline M040 & $2.07 \mathrm{E}+06$ & $2.76 \mathrm{E}+06$ & -835.434371 & 0.87 \\
\hline M062 & $1.37 \mathrm{E}+06$ & $2.55 \mathrm{E}+06$ & -835.435462 & 0.19 \\
\hline M0020 & $3.24 \mathrm{E}+06$ & $2.91 \mathrm{E}+06$ & -835.433048 & 1.70 \\
\hline M0026 & $4.62 \mathrm{E}+06$ & $2.92 \mathrm{E}+06$ & -835.431993 & 2.36 \\
\hline M0042 & $4.71 \mathrm{E}+06$ & $2.96 \mathrm{E}+06$ & -835.432021 & 2.35 \\
\hline M0056 & $4.85 \mathrm{E}+06$ & $3.17 \mathrm{E}+06$ & -835.431996 & 2.36 \\
\hline M0110 & $6.48 \mathrm{E}+06$ & $3.17 \mathrm{E}+06$ & -835.432568 & 2.00 \\
\hline M0186 & $3.18 \mathrm{E}+06$ & $2.75 \mathrm{E}+06$ & -835.432783 & 1.87 \\
\hline M0201 & $5.64 \mathrm{E}+06$ & $3.17 \mathrm{E}+06$ & -835.432767 & 1.88 \\
\hline M0253 & $4.98 \mathrm{E}+06$ & $2.89 \mathrm{E}+06$ & -835.432402 & 2.11 \\
\hline M0274 & $3.57 \mathrm{E}+06$ & $2.99 \mathrm{E}+06$ & -835.432932 & 1.77 \\
\hline M0294 & $4.21 \mathrm{E}+06$ & $3.02 \mathrm{E}+06$ & -835.432707 & 1.92 \\
\hline M0299 & $2.95 \mathrm{E}+06$ & $3.02 \mathrm{E}+06$ & -835.433419 & 1.47 \\
\hline M0370 & $3.15 \mathrm{E}+05$ & $2.43 \mathrm{E}+06$ & -835.435034 & 0.45 \\
\hline M0459 & $3.30 \mathrm{E}+06$ & $2.89 \mathrm{E}+06$ & -835.433156 & 1.63 \\
\hline M0466 & $4.82 \mathrm{E}+06$ & $3.03 \mathrm{E}+06$ & -835.432599 & 1.98 \\
\hline M0712 & $2.78 \mathrm{E}+06$ & $2.69 \mathrm{E}+06$ & -835.43299 & 1.74 \\
\hline M0776 & $2.69 \mathrm{E}+06$ & $2.74 \mathrm{E}+06$ & -835.432757 & 1.88 \\
\hline M0844 & $4.76 \mathrm{E}+06$ & $2.83 \mathrm{E}+06$ & -835.432284 & 2.18 \\
\hline M0859 & $3.46 \mathrm{E}+06$ & $3.18 \mathrm{E}+06$ & -835.432865 & 1.82 \\
\hline M0896 & $2.13 \mathrm{E}+06$ & $2.83 \mathrm{E}+06$ & -835.434183 & 0.99 \\
\hline M1022 & $3.20 \mathrm{E}+06$ & $2.41 \mathrm{E}+06$ & -835.432888 & 1.80 \\
\hline M1084 & $6.70 \mathrm{E}+06$ & $2.81 \mathrm{E}+06$ & -835.431881 & 2.43 \\
\hline M1094 & $2.07 \mathrm{E}+05$ & $2.32 \mathrm{E}+06$ & -835.434454 & 0.82 \\
\hline M1114 & $2.34 \mathrm{E}+06$ & $3.08 \mathrm{E}+06$ & -835.435669 & 0.06 \\
\hline M1123 & $6.21 \mathrm{E}+06$ & $2.49 \mathrm{E}+06$ & -835.433243 & 1.58 \\
\hline M1245 & $3.64 \mathrm{E}+06$ & $3.22 \mathrm{E}+06$ & -835.4348 & 0.60 \\
\hline M1254 & $1.83 \mathrm{E}+06$ & $3.21 \mathrm{E}+06$ & -835.434834 & 0.58 \\
\hline M1262 & $2.78 \mathrm{E}+06$ & $2.98 \mathrm{E}+06$ & -835.433791 & 1.23 \\
\hline M1338 & $1.42 \mathrm{E}+06$ & $3.00 \mathrm{E}+06$ & -835.434412 & 0.85 \\
\hline M1339 & $3.10 \mathrm{E}+06$ & $3.01 \mathrm{E}+06$ & -835.434475 & 0.81 \\
\hline M1362 & $1.91 \mathrm{E}+05$ & $2.02 \mathrm{E}+06$ & -835.434003 & 1.10 \\
\hline M1789 & $2.43 \mathrm{E}+06$ & $2.75 \mathrm{E}+06$ & -835.43476 & 0.63 \\
\hline M1791 & $1.79 \mathrm{E}+06$ & $2.80 \mathrm{E}+06$ & -835.435658 & 0.06 \\
\hline M1930 & $3.09 \mathrm{E}+06$ & $2.89 \mathrm{E}+06$ & -835.435268 & 0.31 \\
\hline M2327 & $1.05 \mathrm{E}+06$ & $2.18 \mathrm{E}+06$ & -835.435759 & 0 \\
\hline M2419 & $7.52 \mathrm{E}+05$ & $2.60 \mathrm{E}+06$ & -835.43439 & 0.86 \\
\hline M2525 & $2.02 \mathrm{E}+06$ & $2.89 \mathrm{E}+06$ & -835.434505 & 0.79 \\
\hline M2533 & $4.33 \mathrm{E}+05$ & $2.14 \mathrm{E}+06$ & -835.43561 & 0.09 \\
\hline M2960 & $9.16 \mathrm{E}+05$ & $2.30 \mathrm{E}+06$ & -835.43528 & 0.30 \\
\hline
\end{tabular}




\begin{tabular}{|l|c|c|r|r|}
\hline M3029 & $2.37 \mathrm{E}+06$ & $2.84 \mathrm{E}+06$ & -835.434129 & 1.02 \\
\hline M3030 & $1.76 \mathrm{E}+06$ & $2.86 \mathrm{E}+06$ & -835.434169 & 1.00 \\
\hline M3293 & $7.83 \mathrm{E}+04$ & $1.94 \mathrm{E}+06$ & -835.434566 & 0.75 \\
\hline
\end{tabular}

Table S17 Conformers of the transition state for the $\mathrm{C}_{6} \mathrm{H}_{9} \mathrm{O}_{8} 1,7 \mathrm{H}$-shift.

\begin{tabular}{|l|r|r|r|r|}
\hline $\begin{array}{l}\text { Conformer } \\
\text { number }\end{array}$ & $\begin{array}{r}\text { Vibrational partition } \\
\text { function }\end{array}$ & $\begin{array}{r}\text { Rotational partition } \\
\text { function }\end{array}$ & $\begin{array}{r}\text { Electronic energy incl. ZPVE } \\
\text { in Hartees }\end{array}$ & $\begin{array}{r}\text { Relative energy in } \\
\mathrm{kcal} / \mathrm{mol}\end{array}$ \\
\hline M001 & $5.20 \mathrm{E}+04$ & $1.87 \mathrm{E}+06$ & -835.399864 & 3.74 \\
\hline $\mathrm{M} 002$ & $4.16 \mathrm{E}+04$ & $1.85 \mathrm{E}+06$ & -835.398755 & 4.43 \\
\hline M002 & $6.75 \mathrm{E}+04$ & $1.91 \mathrm{E}+06$ & -835.403292 & 1.59 \\
\hline M014 & $7.76 \mathrm{E}+04$ & $1.96 \mathrm{E}+06$ & -835.405819 & 0.00 \\
\hline M018 & $6.12 \mathrm{E}+04$ & $1.89 \mathrm{E}+06$ & -835.402376 & 2.16 \\
\hline M022 & $5.06 \mathrm{E}+04$ & $1.95 \mathrm{E}+06$ & -835.404683 & 0.71 \\
\hline
\end{tabular}

1025 Table S18 Conformers of the transition state for the $\mathrm{C}_{6} \mathrm{H}_{9} \mathrm{O}_{8} 1,6 \mathrm{H}$-shift.

\begin{tabular}{|l|r|r|r|r|}
\hline $\begin{array}{l}\text { Conformer } \\
\text { number }\end{array}$ & $\begin{array}{r}\text { Vibrational partition } \\
\text { function }\end{array}$ & $\begin{array}{r}\text { Rotational partition } \\
\text { function }\end{array}$ & $\begin{array}{r}\text { Electronic energy incl. ZPVE } \\
\text { in Hartees }\end{array}$ & $\begin{array}{r}\text { Relative energy in } \\
\text { kcal/mol }\end{array}$ \\
\hline M001 & $4.34 \mathrm{E}+04$ & $2.09 \mathrm{E}+06$ & -835.395859 & 5.70 \\
\hline M002 & $1.73 \mathrm{E}+05$ & $2.47 \mathrm{E}+06$ & -835.397249 & 4.83 \\
\hline M004 & $4.13 \mathrm{E}+04$ & $1.87 \mathrm{E}+06$ & -835.396598 & 5.24 \\
\hline M005 & $4.85 \mathrm{E}+04$ & $1.87 \mathrm{E}+06$ & -835.396372 & 5.38 \\
\hline M015 & $1.34 \mathrm{E}+05$ & $2.54 \mathrm{E}+06$ & -835.404258 & 0.43 \\
\hline M017 & $1.90 \mathrm{E}+05$ & $2.52 \mathrm{E}+06$ & -835.404943 & 0.00 \\
\hline M024 & $1.75 \mathrm{E}+05$ & $2.42 \mathrm{E}+06$ & -835.402895 & 1.29 \\
\hline M068 & $1.35 \mathrm{E}+05$ & $2.32 \mathrm{E}+06$ & -835.403966 & 0.61 \\
\hline M071 & $2.36 \mathrm{E}+05$ & $2.59 \mathrm{E}+06$ & -835.404766 & 0.11 \\
\hline M118 & $1.12 \mathrm{E}+05$ & $2.51 \mathrm{E}+06$ & -835.403913 & 0.65 \\
\hline
\end{tabular}


1030 Table S19 Conformers of the transition state for the $\mathrm{C}_{6} \mathrm{H}_{9} \mathrm{O}_{8} 1,5 \mathrm{H}$-shift.

\begin{tabular}{|l|r|r|r|r|}
\hline $\begin{array}{l}\text { Conformer } \\
\text { number }\end{array}$ & $\begin{array}{r}\text { Vibrational partition } \\
\text { function }\end{array}$ & $\begin{array}{r}\text { Rotational partition } \\
\text { function }\end{array}$ & $\begin{array}{r}\text { Electronic energy incl. ZPVE } \\
\text { in Hartees }\end{array}$ & $\begin{array}{r}\text { Relative energy in } \\
\text { kcal/mol }\end{array}$ \\
\hline M005 & $2.54 \mathrm{E}+05$ & $2.10 \mathrm{E}+06$ & -835.402026 & 0.21 \\
\hline M029 & $1.51 \mathrm{E}+05$ & $2.14 \mathrm{E}+06$ & -835.399485 & 1.81 \\
\hline M047 & $1.54 \mathrm{E}+05$ & $2.02 \mathrm{E}+06$ & -835.400130 & 1.40 \\
\hline M056 & $1.17 \mathrm{E}+05$ & $2.10 \mathrm{E}+06$ & -835.400313 & 1.29 \\
\hline M032 & $2.58 \mathrm{E}+05$ & $2.50 \mathrm{E}+06$ & -835.402364 & 0 \\
\hline M018 & $1.22 \mathrm{E}+06$ & $2.15 \mathrm{E}+06$ & -835.395691 & 4.19 \\
\hline M021 & $1.52 \mathrm{E}+06$ & $2.82 \mathrm{E}+06$ & -835.396649 & 3.59 \\
\hline M065 & $9.72 \mathrm{E}+05$ & $2.23 \mathrm{E}+06$ & -835.394663 & 4.83 \\
\hline M075 & $1.14 \mathrm{E}+06$ & $2.98 \mathrm{E}+06$ & -835.395693 & 4.19 \\
\hline M078 & $1.19 \mathrm{E}+06$ & $2.61 \mathrm{E}+06$ & -835.397479 & 3.07 \\
\hline M123 & $1.85 \mathrm{E}+06$ & $2.88 \mathrm{E}+06$ & -835.395038 & 4.60 \\
\hline M136 & $8.28 \mathrm{E}+05$ & $2.63 \mathrm{E}+06$ & -835.396288 & 3.81 \\
\hline M151 & $1.31 \mathrm{E}+06$ & $2.54 \mathrm{E}+06$ & -835.396115 & 3.92 \\
\hline M167 & $1.18 \mathrm{E}+06$ & $2.54 \mathrm{E}+06$ & -835.395784 & 4.13 \\
\hline M168 & $1.06 \mathrm{E}+06$ & $2.55 \mathrm{E}+06$ & -835.395663 & 4.20 \\
\hline M192 & $1.01 \mathrm{E}+06$ & $2.51 \mathrm{E}+06$ & -835.396118 & 3.92 \\
\hline M252 & $1.41 \mathrm{E}+06$ & $2.96 \mathrm{E}+06$ & -835.393976 & 5.26 \\
\hline M301 & $1.30 \mathrm{E}+06$ & $2.38 \mathrm{E}+06$ & -835.395021 & 4.61 \\
\hline
\end{tabular}

Table S20 Conformers of the transition state for the $\mathrm{C}_{6} \mathrm{H}_{9} \mathrm{O}_{8} 1,4 \mathrm{H}$-shift.

\begin{tabular}{|l|r|r|r|r|}
\hline $\begin{array}{l}\text { Conformer } \\
\text { number }\end{array}$ & $\begin{array}{r}\text { Vibrational partition } \\
\text { function }\end{array}$ & $\begin{array}{r}\text { Rotational partition } \\
\text { function }\end{array}$ & $\begin{array}{r}\text { Electronic energy incl. ZPVE } \\
\text { in Hartees }\end{array}$ & $\begin{array}{r}\text { Relative energy in } \\
\text { kcal/mol }\end{array}$ \\
\hline M115 & $5.45 \mathrm{E}+05$ & $2.16 \mathrm{E}+06$ & -835.403992 & 0.25 \\
\hline M120 & $7.18 \mathrm{E}+04$ & $1.75 \mathrm{E}+06$ & -835.399104 & 3.32 \\
\hline M121 & $1.05 \mathrm{E}+05$ & $1.80 \mathrm{E}+06$ & -835.399993 & 2.76 \\
\hline M124 & $1.18 \mathrm{E}+05$ & $2.01 \mathrm{E}+06$ & -835.397158 & 4.54 \\
\hline M243 & $6.04 \mathrm{E}+04$ & $1.65 \mathrm{E}+06$ & -835.399997 & 2.76 \\
\hline M303 & $7.32 \mathrm{E}+04$ & $1.64 \mathrm{E}+06$ & -835.398274 & 3.84 \\
\hline M357 & $1.01 \mathrm{E}+05$ & $1.97 \mathrm{E}+06$ & -835.399749 & 2.92 \\
\hline M019 & $1.57 \mathrm{E}+06$ & $2.62 \mathrm{E}+06$ & -835.403500 & 0.56 \\
\hline M041 & $1.04 \mathrm{E}+06$ & $2.80 \mathrm{E}+06$ & -835.403439 & 0.60 \\
\hline M058 & $1.26 \mathrm{E}+06$ & $2.74 \mathrm{E}+06$ & -835.403201 & 0.75 \\
\hline M079 & $1.61 \mathrm{E}+06$ & $2.69 \mathrm{E}+06$ & -835.402632 & 1.11 \\
\hline M097 & $1.04 \mathrm{E}+06$ & $2.80 \mathrm{E}+06$ & -835.403440 & 0.60 \\
\hline M1093 & $9.11 \mathrm{E}+05$ & $2.41 \mathrm{E}+06$ & -835.403555 & 0.53 \\
\hline M1133 & $9.85 \mathrm{E}+05$ & $2.41 \mathrm{E}+06$ & -835.402013 & 1.49 \\
\hline M115 & $8.63 \mathrm{E}+05$ & $2.60 \mathrm{E}+06$ & -835.403361 & 0.65 \\
\hline M120 & $1.01 \mathrm{E}+06$ & $2.72 \mathrm{E}+06$ & -835.403662 & 0.46 \\
\hline M1321 & $8.65 \mathrm{E}+05$ & $2.05 \mathrm{E}+06$ & -835.402554 & 1.16 \\
\hline M135 & $1.41 \mathrm{E}+06$ & $3.05 \mathrm{E}+06$ & -835.402690 & 1.07 \\
\hline M1460 & $1.25 \mathrm{E}+06$ & $2.58 \mathrm{E}+06$ & -835.401592 & 1.76 \\
\hline
\end{tabular}




\begin{tabular}{|c|c|c|c|c|}
\hline M151 & $2.77 \mathrm{E}+06$ & $2.81 \mathrm{E}+06$ & -835.402635 & 1.10 \\
\hline M160 & $2.94 \mathrm{E}+06$ & $2.82 \mathrm{E}+06$ & -835.400954 & 2.16 \\
\hline M192 & $1.43 \mathrm{E}+06$ & $2.79 \mathrm{E}+06$ & -835.402486 & 1.20 \\
\hline M1941 & $1.14 \mathrm{E}+06$ & $2.58 \mathrm{E}+06$ & -835.401703 & 1.69 \\
\hline M202 & $1.65 \mathrm{E}+06$ & $2.64 \mathrm{E}+06$ & -835.401502 & 1.82 \\
\hline M216 & $2.72 \mathrm{E}+06$ & $3.07 \mathrm{E}+06$ & -835.400985 & 2.14 \\
\hline M222 & $1.22 \mathrm{E}+06$ & $2.94 \mathrm{E}+06$ & -835.402717 & 1.05 \\
\hline M250 & $1.04 \mathrm{E}+06$ & $2.70 \mathrm{E}+06$ & -835.403205 & 0.75 \\
\hline M267 & $3.08 \mathrm{E}+06$ & $2.83 \mathrm{E}+06$ & -835.401043 & 2.10 \\
\hline M296 & $1.58 \mathrm{E}+06$ & $2.62 \mathrm{E}+06$ & -835.401378 & 1.89 \\
\hline M301 & $1.21 \mathrm{E}+06$ & $2.68 \mathrm{E}+06$ & -835.403987 & 0.26 \\
\hline M322 & $2.90 \mathrm{E}+06$ & $3.08 \mathrm{E}+06$ & -835.400978 & 2.14 \\
\hline M354 & $4.21 \mathrm{E}+06$ & $2.93 \mathrm{E}+06$ & -835.402677 & 1.08 \\
\hline M453 & $1.04 \mathrm{E}+06$ & $2.80 \mathrm{E}+06$ & -835.403441 & 0.60 \\
\hline M456 & $1.78 \mathrm{E}+06$ & $2.77 \mathrm{E}+06$ & -835.401107 & 2.06 \\
\hline M514 & $8.36 \mathrm{E}+05$ & $2.50 \mathrm{E}+06$ & -835.402797 & 1.00 \\
\hline M548 & $1.63 \mathrm{E}+05$ & $2.02 \mathrm{E}+06$ & -835.402815 & 0.99 \\
\hline M625 & $1.39 \mathrm{E}+06$ & $2.73 E+06$ & -835.401975 & 1.52 \\
\hline M701 & $1.70 \mathrm{E}+06$ & $2.76 \mathrm{E}+06$ & -835.401822 & 1.61 \\
\hline M727 & $2.95 \mathrm{E}+05$ & $2.01 \mathrm{E}+06$ & -835.404395 & 0 \\
\hline M758 & $9.63 \mathrm{E}+05$ & $2.28 \mathrm{E}+06$ & -835.403017 & 0.86 \\
\hline M780 & $1.20 \mathrm{E}+06$ & $2.49 \mathrm{E}+06$ & -835.401164 & 2.03 \\
\hline M838 & $7.57 \mathrm{E}+05$ & $2.07 \mathrm{E}+06$ & -835.402357 & 1.28 \\
\hline M856 & $4.15 \mathrm{E}+06$ & $2.54 \mathrm{E}+06$ & -835.402584 & 1.14 \\
\hline M931 & $8.32 \mathrm{E}+05$ & $2.47 \mathrm{E}+06$ & -835.401136 & 2.05 \\
\hline M949 & $6.39 \mathrm{E}+05$ & $2.09 \mathrm{E}+06$ & -835.402406 & 1.25 \\
\hline
\end{tabular}

Table 21 Conformers of the product for the $\mathrm{C}_{6} \mathrm{H}_{9} \mathrm{O}_{8} 1,7 \mathrm{H}$-shift.

\begin{tabular}{|l|r|r|r|r|}
\hline $\begin{array}{l}\text { Conformer } \\
\text { number }\end{array}$ & $\begin{array}{r}\text { Vibrational partition } \\
\text { function }\end{array}$ & $\begin{array}{r}\text { Rotational partition } \\
\text { function }\end{array}$ & $\begin{array}{r}\text { Electronic energy incl. ZPVE } \\
\text { in Hartees }\end{array}$ & $\begin{array}{r}\text { Relative energy in } \\
\text { kcal/mol }\end{array}$ \\
\hline M000 & $1.49 \mathrm{E}+06$ & $2.98 \mathrm{E}+06$ & -835.436576 & 1.40 \\
\hline M003 & $1.44 \mathrm{E}+06$ & $3.13 \mathrm{E}+06$ & -835.437096 & 1.07 \\
\hline M007 & $5.78 \mathrm{E}+05$ & $2.32 \mathrm{E}+06$ & -835.437399 & 0.88 \\
\hline M010 & $1.02 \mathrm{E}+06$ & $3.04 \mathrm{E}+06$ & -835.436427 & 1.49 \\
\hline M012 & $1.69 \mathrm{E}+06$ & $2.80 \mathrm{E}+06$ & -835.436149 & 1.67 \\
\hline M015 & $5.75 \mathrm{E}+06$ & $3.17 \mathrm{E}+06$ & -835.435921 & 1.81 \\
\hline M016 & $7.36 \mathrm{E}+05$ & $2.33 \mathrm{E}+06$ & -835.438204 & 0.38 \\
\hline M017 & $7.36 \mathrm{E}+05$ & $2.33 \mathrm{E}+06$ & -835.438205 & 0.38 \\
\hline M019 & $1.06 \mathrm{E}+06$ & $2.57 \mathrm{E}+06$ & -835.436976 & 1.15 \\
\hline M023 & $2.00 \mathrm{E}+06$ & $3.01 \mathrm{E}+06$ & -835.436019 & 1.75 \\
\hline M029 & $3.93 \mathrm{E}+06$ & $2.79 \mathrm{E}+06$ & -835.437333 & 0.93 \\
\hline M039 & $2.22 \mathrm{E}+06$ & $3.23 \mathrm{E}+06$ & -835.438315 & 0.31 \\
\hline M047 & $1.45 \mathrm{E}+06$ & $3.11 \mathrm{E}+06$ & -835.436338 & 1.55 \\
\hline M063 & $1.58 \mathrm{E}+06$ & $2.80 \mathrm{E}+06$ & -835.436810 & 1.25 \\
\hline
\end{tabular}




\begin{tabular}{|c|c|c|c|c|}
\hline M069 & $7.79 \mathrm{E}+05$ & $2.67 \mathrm{E}+06$ & -835.436754 & 1.29 \\
\hline M070 & $1.25 \mathrm{E}+06$ & $2.59 \mathrm{E}+06$ & -835.437970 & 0.53 \\
\hline M071 & $2.48 \mathrm{E}+06$ & $3.09 \mathrm{E}+06$ & -835.436656 & 1.35 \\
\hline M072 & $6.51 \mathrm{E}+05$ & $2.28 \mathrm{E}+06$ & -835.438561 & 0.15 \\
\hline M079 & $2.73 \mathrm{E}+06$ & $2.95 \mathrm{E}+06$ & -835.437986 & 0.52 \\
\hline M080 & $8.16 \mathrm{E}+05$ & $2.26 \mathrm{E}+06$ & -835.436383 & 1.52 \\
\hline M091 & $2.18 \mathrm{E}+06$ & $2.92 \mathrm{E}+06$ & -835.436527 & 1.43 \\
\hline M099 & $3.94 \mathrm{E}+06$ & $2.79 \mathrm{E}+06$ & -835.437334 & 0.92 \\
\hline M102 & $2.81 \mathrm{E}+06$ & $3.01 \mathrm{E}+06$ & -835.438007 & 0.50 \\
\hline M110 & $2.28 \mathrm{E}+06$ & $3.06 \mathrm{E}+06$ & -835.436694 & 1.33 \\
\hline M111 & $1.35 \mathrm{E}+06$ & $2.75 \mathrm{E}+06$ & -835.437382 & 0.89 \\
\hline M113 & $9.47 \mathrm{E}+05$ & $2.29 \mathrm{E}+06$ & -835.437730 & 0.68 \\
\hline M115 & $9.46 \mathrm{E}+05$ & $2.29 \mathrm{E}+06$ & -835.437729 & 0.68 \\
\hline M130 & $4.64 \mathrm{E}+06$ & $3.38 \mathrm{E}+06$ & -835.437577 & 0.77 \\
\hline M143 & $1.14 \mathrm{E}+06$ & $2.31 \mathrm{E}+06$ & -835.438808 & 0 \\
\hline M144 & $4.75 \mathrm{E}+05$ & $2.06 \mathrm{E}+06$ & -835.438522 & 0.18 \\
\hline M147 & $5.63 \mathrm{E}+05$ & $2.16 \mathrm{E}+06$ & -835.438226 & 0.37 \\
\hline M153 & $2.20 \mathrm{E}+05$ & $2.52 \mathrm{E}+06$ & -835.436013 & 1.75 \\
\hline M158 & $3.49 \mathrm{E}+05$ & $2.45 \mathrm{E}+06$ & -835.437600 & 0.76 \\
\hline M159 & $1.35 \mathrm{E}+06$ & $3.05 \mathrm{E}+06$ & -835.435747 & 1.92 \\
\hline M162 & $2.37 \mathrm{E}+05$ & $2.38 \mathrm{E}+06$ & -835.437695 & 0.70 \\
\hline M163 & $2.00 \mathrm{E}+06$ & $3.37 \mathrm{E}+06$ & -835.436440 & 1.49 \\
\hline M087 & $9.29 \mathrm{E}+05$ & $2.35 \mathrm{E}+06$ & -835.435830 & 1.87 \\
\hline M097 & $1.80 \mathrm{E}+06$ & $2.77 \mathrm{E}+06$ & -835.435778 & 1.90 \\
\hline M108 & $6.72 \mathrm{E}+05$ & $2.35 \mathrm{E}+06$ & -835.437630 & 0.74 \\
\hline M113 & $1.34 \mathrm{E}+06$ & $2.96 \mathrm{E}+06$ & -835.434991 & 2.40 \\
\hline M114 & $1.02 \mathrm{E}+06$ & $2.91 \mathrm{E}+06$ & -835.434771 & 2.53 \\
\hline M119 & $2.98 \mathrm{E}+05$ & $2.40 \mathrm{E}+06$ & -835.437179 & 1.02 \\
\hline M121 & $2.57 \mathrm{E}+06$ & $2.72 \mathrm{E}+06$ & -835.435209 & 2.26 \\
\hline M123 & $2.57 \mathrm{E}+06$ & $2.72 \mathrm{E}+06$ & -835.435208 & 2.26 \\
\hline M139 & $2.81 \mathrm{E}+06$ & $3.01 \mathrm{E}+06$ & -835.438008 & 0.50 \\
\hline M147 & $3.45 \mathrm{E}+06$ & $3.23 \mathrm{E}+06$ & -835.436745 & 1.29 \\
\hline M148 & $1.63 \mathrm{E}+05$ & $2.44 \mathrm{E}+06$ & -835.437511 & 0.81 \\
\hline M151 & $1.45 \mathrm{E}+06$ & $3.13 \mathrm{E}+06$ & -835.437097 & 1.07 \\
\hline M152 & $8.35 \mathrm{E}+05$ & $2.34 \mathrm{E}+06$ & -835.436421 & 1.50 \\
\hline M155 & $4.02 \mathrm{E}+06$ & $3.31 \mathrm{E}+06$ & -835.434282 & 2.84 \\
\hline M176 & $1.84 \mathrm{E}+05$ & $2.19 \mathrm{E}+06$ & -835.436641 & 1.36 \\
\hline
\end{tabular}


Table 22 Conformers of the product for the $\mathrm{C}_{6} \mathrm{H}_{9} \mathrm{O}_{8} 1,6 \mathrm{H}$-shift.

\begin{tabular}{|c|c|c|c|c|}
\hline $\begin{array}{l}\text { Conformer } \\
\text { number }\end{array}$ & $\begin{array}{r}\text { Vibrational partition } \\
\text { function } \\
\end{array}$ & $\begin{array}{r}\text { Rotational partition } \\
\text { function } \\
\end{array}$ & $\begin{array}{r}\text { Electronic energy incl. } \\
\text { ZPVE in Hartees } \\
\end{array}$ & $\begin{array}{r}\text { Relative energy in } \\
\mathrm{kcal} / \mathrm{mol}\end{array}$ \\
\hline M113 & $1.11 \mathrm{E}+05$ & $1.79 \mathrm{E}+06$ & -835.43014 & 0.24 \\
\hline M446 & $5.69 \mathrm{E}+05$ & $2.30 \mathrm{E}+06$ & -835.42949 & 0.65 \\
\hline M454 & $1.26 \mathrm{E}+06$ & $2.30 \mathrm{E}+06$ & -835.42983 & 0.43 \\
\hline M476 & $2.81 \mathrm{E}+06$ & $2.38 \mathrm{E}+06$ & -835.42758 & 1.84 \\
\hline M478 & $8.00 \mathrm{E}+05$ & $2.24 \mathrm{E}+06$ & -835.42965 & 0.55 \\
\hline M490 & $9.53 \mathrm{E}+05$ & $2.20 \mathrm{E}+06$ & -835.42922 & 0.82 \\
\hline M026 & $2.64 \mathrm{E}+06$ & $2.32 \mathrm{E}+06$ & -835.42709 & 2.15 \\
\hline M057 & $4.02 \mathrm{E}+06$ & $2.73 \mathrm{E}+06$ & -835.42862 & 1.19 \\
\hline M1001 & $3.49 \mathrm{E}+06$ & $2.98 \mathrm{E}+06$ & -835.42934 & 0.74 \\
\hline M1064 & $1.35 \mathrm{E}+05$ & $1.78 \mathrm{E}+06$ & -835.42896 & 0.98 \\
\hline M1146 & $1.33 \mathrm{E}+06$ & $2.61 \mathrm{E}+06$ & -835.42941 & 0.70 \\
\hline M1170 & $4.02 \mathrm{E}+06$ & $2.73 \mathrm{E}+06$ & -835.42862 & 1.19 \\
\hline M1285 & $2.82 \mathrm{E}+06$ & $2.80 \mathrm{E}+06$ & -835.42970 & 0.51 \\
\hline M1300 & $2.14 \mathrm{E}+05$ & $2.05 \mathrm{E}+06$ & -835.43052 & 0 \\
\hline M1414 & $8.11 \mathrm{E}+06$ & $2.99 \mathrm{E}+06$ & -835.42920 & 0.82 \\
\hline M1417 & $3.42 \mathrm{E}+06$ & $2.93 \mathrm{E}+06$ & -835.42923 & 0.81 \\
\hline M150 & $1.08 \mathrm{E}+06$ & $2.22 \mathrm{E}+06$ & -835.42750 & 1.89 \\
\hline M171 & $5.40 \mathrm{E}+06$ & $2.92 \mathrm{E}+06$ & -835.42793 & 1.63 \\
\hline M1735 & $5.93 \mathrm{E}+06$ & $3.16 \mathrm{E}+06$ & -835.42754 & 1.87 \\
\hline M173 & $2.82 \mathrm{E}+06$ & $2.72 \mathrm{E}+06$ & -835.42957 & 0.59 \\
\hline M267 & $6.60 \mathrm{E}+05$ & $2.40 \mathrm{E}+06$ & -835.42955 & 0.61 \\
\hline M321 & $5.56 \mathrm{E}+06$ & $2.68 \mathrm{E}+06$ & -835.42805 & 1.55 \\
\hline M333 & $1.12 \mathrm{E}+06$ & $2.25 \mathrm{E}+06$ & -835.42742 & 1.94 \\
\hline M398 & $4.11 \mathrm{E}+06$ & $3.25 \mathrm{E}+06$ & -835.42788 & 1.66 \\
\hline M477 & $6.75 \mathrm{E}+06$ & $3.40 \mathrm{E}+06$ & -835.42840 & 1.33 \\
\hline M492 & $2.83 \mathrm{E}+06$ & $2.72 \mathrm{E}+06$ & -835.42957 & 0.59 \\
\hline M539 & $2.91 \mathrm{E}+06$ & $2.88 \mathrm{E}+06$ & -835.42844 & 1.31 \\
\hline M790 & $4.13 E+05$ & $1.81 \mathrm{E}+06$ & -835.42751 & 1.89 \\
\hline M863 & $5.14 \mathrm{E}+06$ & $2.53 \mathrm{E}+06$ & -835.42802 & 1.57 \\
\hline M903 & $3.08 \mathrm{E}+06$ & $2.61 \mathrm{E}+06$ & -835.42823 & 1.44 \\
\hline M965 & $3.07 \mathrm{E}+06$ & $2.85 \mathrm{E}+06$ & -835.42801 & 1.57 \\
\hline
\end{tabular}

\section{References that appear only in the SI:}

[91] Kürten, A.; Rondo, L.; Ehrhart, S.; Curtius J. J. Phys. Chem. A 2012, 116, 6375-6386.

[92] Docherty, K. S.; Ziemann, P. J. Aerosol Sci. Technol. 2003, 37, 877-891.

[93] Ziemann, P.; Atkinson, R. Chem. Soc. Rev. 2012, 41, 6582-6605.

[94] Peeters, J.; Nguyen, T. L.; Vereecken, L. Phys. Chem. Chem. Phys. 2009, 11, 5935-5939.

1050 [95] Vereecken, L.; Peeters, J. Phys. Chem. Chem. Phys. 2010, 12, 12608-12620. 
1051 [96] Scheer, A. M.; Welz, O.; Zádor, J.; Osborn, D. L.; Taatjes, C. A. Phys. Chem. Chem. Phys. 2014, 16, 13027-13040. 1052 [97] Lelieveld, J.; Butler, T. M.; Crowley, J. N.; Dillon, T. J.; Fischer, H.; Ganzeveld, L.; Harder, H.; Lawrence, M. G.; 1053 Martinez, M.; Taraborrelli, D.; Williams, J. Nature, 2008, 452, 737-740.

1054 [98] Fuchs, H.; Hofzumahaus, A.; Rohrer, F.; Bohn, B.; Brauers, T.; Dorn, H-P.; Häseler, R.; Holland, F.; Kaminski, M.; 1055 Li, X.; Lu, K.; Nehr, S.; Tillmann, R.; Wegener, R.; Wahner, A. Nature Geo. 2013, 6, 1023-1026.

1056 [99] Lockhart, J.; Blitz, M.; Heard, D.; Seakins, P.; Shannon, R. J. Phys. Chem. A 2013, 117, $11027-11037$.

1057 [100] Lockhart, J.; Blitz, M. A.; Heard, D. E.; Seakins, P. W.; Shannon R. J. J. Phys. Chem. A 2013, 117, 5407-5418.

1058 [101] Peeters, J.; Müller, J. F. Phys. Chem. Chem. Phys. 2010, 12, 14227-14235.

1059 [102] Yu, T.; Truhlar, D. G. Chem. Sci. 2011, 2, 2199-2213.

1060 [103] Zheng, J.; Truhlar, D. G. J. Chem. Theory and Comput. 2013, 9, 1356-1367. 